INTER NATIONAL MONETARY FUND
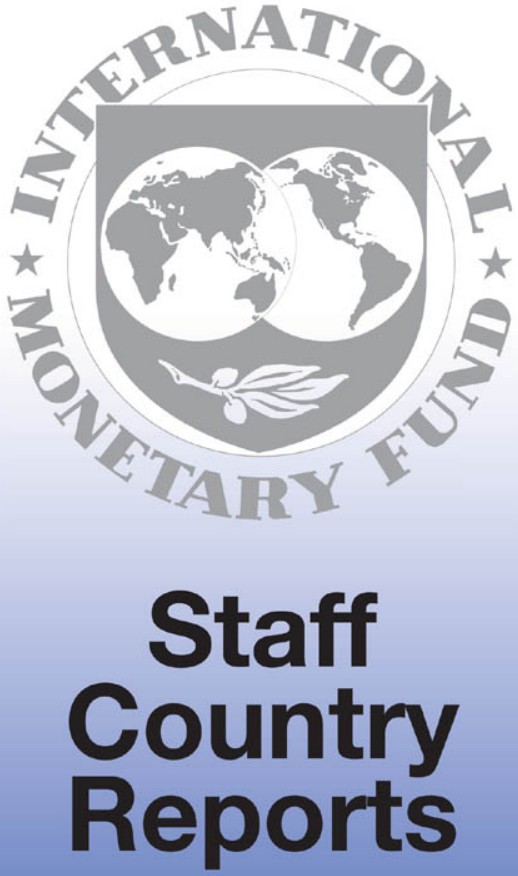


\section{Rwanda: 2010 Article IV Consultation and First Review Under the Policy Support Instrument-Staff Report; Public Information Notice and Press Release on the Executive Board Discussion; and Statement by the Executive Director for Rwanda.}

Under Article IV of the IMF's Articles of Agreement, the IMF holds bilateral discussions with members, usually every year. In the context of a combined discussion of the 2010 Article IV consultation with Rwanda and First Review Under the Policy Support Instrument, the following documents have been released and are included in this package:

- $\quad$ The staff report for the combined 2010 Article IV consultation and First Review Under the Policy Support Instrument, and Modification of Assessment Criteria, prepared by a staff team of the IMF, following discussions that ended on October 26, 2010, with the officials of Rwanda on economic developments and policies. Based on information available at the time of these discussions, the staff report was completed on December 6, 2010. The views expressed in the staff report are those of the staff team and do not necessarily reflect the views of the Executive Board of the IMF.

- A Public Information Notice (PIN) and Press Release, summarizing the views of the Executive Board as expressed during its December 20,2010, discussion of the staff report on issues related to the Article IV consultation and the IMF arrangement, respectively.

- $\quad$ A statement by the Executive Director for Rwanda.

The documents listed below have been or will be separately released.

Letter of Intent sent to the IMF by the authorities of Rwanda*

Memorandum of Economic and Financial Policies by the authorities of

Rwanda*

Technical Memorandum of Understanding*

*Also included in Staff Report

The policy of publication of staff reports and other documents allows for the deletion of market-sensitive information.

Copies of this report are available to the public from

International Monetary Fund • Publication Services

$70019^{\text {th }}$ Street, N.W. • Washington, D.C. 20431

Telephone: (202) 623-7430 • Telefax: (202) 623-7201

E-mail: publications@imf.org Internet: http://www.imf.org

\section{International Monetary Fund Washington, D.C.}


INTERNATIONAL MONETARY FUND

RWANDA

\section{Article IV Consultation, First Review Under the Policy Support Instrument, and Modification of Assessment Criteria}

Prepared by the African Department

(in consultation with other departments)

Approved by Saul Lizondo and Christian Mumssen

December 6, 2010

Discussions were held in Kigali during October 12-26. The team included Ms. McAuliffe (head), Mr. Davoodi, Mr. Opoku-Afari, and Mr. Yabara (all AFR), Mr. Geiregat (SPR), and was assisted by Mr. Gershenson, resident representative. The team met with Minister of Finance and Economic Planning Rwangombwa, Governor of the National Bank of Rwanda Kanimba, heads of key government agencies, other officials, representatives of the private sector, and commercial banks.

High-level outreach and seminar. A series of high-level meetings and outreach events were held for the full parliament, Cabinet of Ministers and other high level government officials, civil society, private sector, development partners, and the press. The meeting with Cabinet discussed the challenges of scaling up investment in infrastructure in a sustainable manner. The outreach and meetings were very well received and all participants requested that the dialogue continue on future missions.

The exchange rate regime is classified as crawl-like arrangement, effective January 4, 2010, given the recent movement of the Rwandan franc against the dollar. Rwanda has accepted the obligations of Article VIII, sections 2, 3, and 4, and maintains a system free of restrictions on the making of payments and transfers for current international transactions. 


\section{Key Issues and Recommendations}

- Context: Recovery has resumed, while inflation remains subdued in 2010. Looking ahead, growth remains steady but inflation is projected to pick up slightly in 2011 . Downside risks relate to slower pickup in external demand and domestic credit. After a large increase in 2009-2010, donor flows are expected to return to trend levels, but decline gradually over the medium-term.

- Unwinding fiscal stimulus gradually: The unwinding of a sizable stimulus in 2009-10 is underpinned by the ongoing front loading of revenue increases, despite some recent downward revision in the revenue outlook. The authorities are strengthening their medium term fiscal framework which envisages further consolidation over the mediumterm. Looking ahead, tax policy reforms are needed in order to support the ongoing improvements in tax administration.

- Mapping an Effective Monetary and Exchange Rate Policy: The accommodative monetary policy stance is appropriate, but needs to be revisited depending on inflationary pressures. The NBR should continue to use appropriate mix of monetary policy instruments, including greater exchange rate flexibility, to support the objective of maintaining low and stable inflation.

- Strengthening Financial Stability while Deepening Financial Markets: The authorities are on track to complete the planned number of on-site bank inspections. However, the high turnover of trained bank examiners continues to weaken the supervisory capacity at the NBR, and remains a potential source of vulnerability. There is a need to deepen the financial sector, but the decision to grant lending licenses to additional micro finance institutions and saving and credit cooperatives is a cause for concern, given the high and growing non-performing loans in the sector as well as limited supervision capacity at the NBR and other institutions.

- Boosting Competiveness and Growth: Staff analysis indicates that the real exchange rate is broadly in line with fundamentals. The authorities are mindful of a low export revenue base and intend to improve Rwanda's competitiveness and growth through improving the business environment, developing a viable export diversification strategy and scaling up investment in strategic sectors using nonconcessional financing and Public Private Partnerships (PPPs). Staff welcomes the authorities' cautious approach to granting tax incentives to potential investors and to fully assessing fiscal risks associated with PPPs.

- Fund relations: On June 16, 2010, the Executive Board approved a three-year PSI-supported program. All end-June assessment criteria were met, and notable progress was made in implementing structural benchmarks. Staff recommends completion of the first review under the PSI, and modification of the assessment criteria for end-December 2010 . 


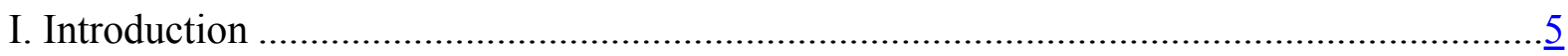

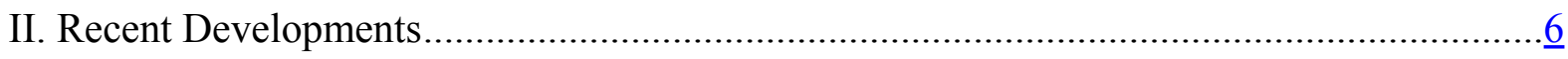

III. Program Performance .................................................................................. 14

IV. Policy Discussions: Maintaining Macroeconomic Stability while Boosting Growth and Competitiveness ............................................................................................ $\frac{15}{15}$

A. Outlook and Risks ................................................................................ $\frac{15}{19}$

B. Unwinding Fiscal Stimulus Gradually .......................................................... $\frac{19}{23}$

C. Mapping an Effective Monetary and Exchange Rate Policy ...............................23

D. Strengthening Financial Stability While Deepening Financial Markets................ 27

E. Boosting Competiveness and Growth ......................................................

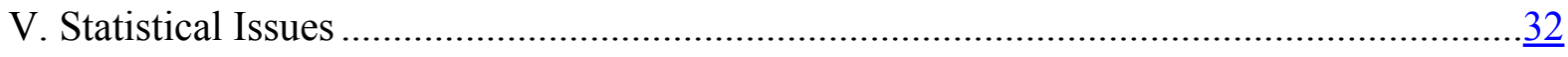

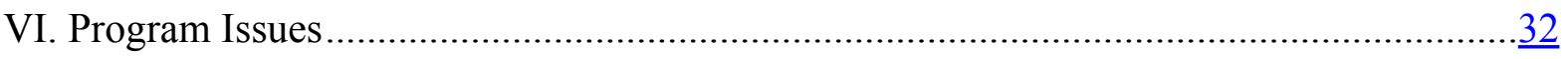

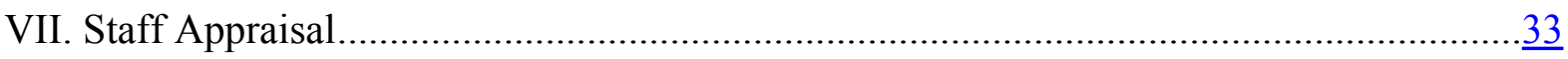

Tables

1. Millenium Development Goals........................................................................... $\frac{36}{37}$

2. Selected Economic and Financial Indicators, 2006-15 ............................................... $\underline{37}$

3. Balance of Payments, 2007-15 ............................................................................... $\frac{38}{39}$

4. Operations of the Central Government, Fiscal Year Basis, 2006/7-14/15 .......................

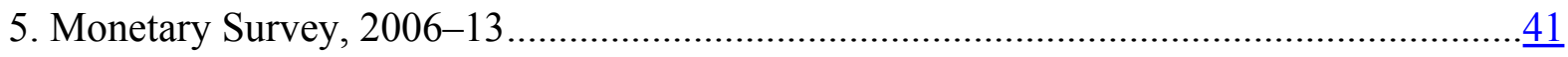

6. Financial Soundness Indicators for Banking Sector, 2006-2010 ................................. 43

Figures

1. Recent Performances, Achievements, and Challenges .................................................. $\underline{8}$

2. Selected high Frequency Indicators of Economic Activity, Jan 2006-Sep 2010 ............... 9

3. External Developments, 2005-10 ........................................................................... 10

4. Fiscal Developments, 2005-10 .............................................................................

5. Monetary and Financial Developments, 2004-10 ….................................................. 12

6. Developments in the Financial Sector, 2003-September 2010 ....................................13

7. Medium-Term Outlook, 2008-15 …................................................................... 17

8. Exchange Rate Assessment.................................................................................. $\underline{30}$

9. Indicators of Competitiveness.................................................................................. 
Boxes

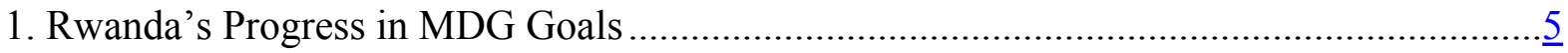

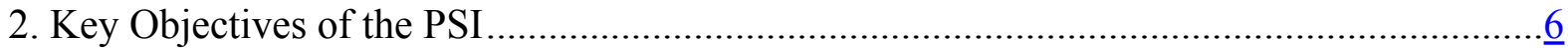

3. Sources of Rwanda's Economic Growth ...................................................................... 18

4. Monetary Transmission Mechanism in Rwanda ....................................................

5. Exchange Rate Assessment and External Competitiveness............................................29

Appendices

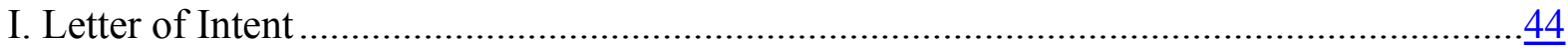

Attachment I. Memorandum of Economic and Financial Policies .................................. 47

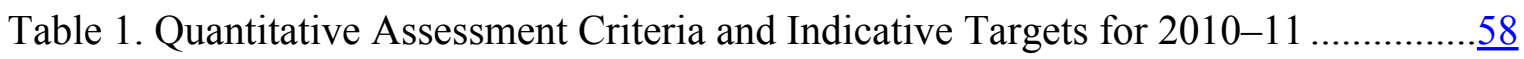

Table 2. Structural Benchmarks for 2010-11 ........................................................59

Attachment II. Technical Memorandum of Understanding .............................................60

Table 1. Summary of Reporting Requirements ................................................... 69

II. Sources of Growth Using a Growth Accounting Framework ....................................... $\underline{70}$ 


\section{INTRODUCTION}

1. Rwanda has achieved high growth and macroeconomic stability over the last decade, but poverty remains high. Growth has averaged about 8 percent a year. ${ }^{1}$ Inflation, though volatile, is now in low single digits, and international reserves are at comfortable levels. The financial sector has deepened over the last decade with the ratio of private sector credit to GDP increasing six-fold to 12 percent of GDP. Rwanda's resilience to external shocks has also improved further-thanks to prudent policies, substantial debt relief, and heavy reliance on concessional borrowing. However, poverty remains high, with 57 percent of the population living below the national poverty line in 2006. Although Rwanda is unlikely to meet most of the Millennium Development Goals (MDGs), including halving its poverty by 2015, significant progress has been made in many areas (Table 1 and Box 1).

\section{Box 1. Rwanda's Progress in MDG Goals ${ }^{1}$}

- Number of seats held by women in the Rwanda's parliament increased from 17 percent in 1994 to 52 percent in 2008, the highest in the world.

- Rwanda is very likely to meet - and possibly even surpass - the MDG targets for child and maternal mortality by 2015 .

- The rate of births attended by skilled staff increased from 39 percent to 52 percent between 2005 and 2008 .

- Proportion of children under five sleeping under insecticide-treated bed nets increased from 4 percent in 2000 to 56 percent in 2008/09.

${ }^{1}$ Source: United Nations, Millennium Development Goals Report (2010)

\section{The authorities have strengthened their policies, in line with advice from the last} Article IV consultation and subsequent program discussions. Policy implementation has improved significantly, including reforms in Public Financial Management (PFM) through a basket fund supported and monitored regularly by donors; delivering positive real interest rate on bank deposits; using countercyclical fiscal and monetary policies to mitigate the adverse effects of the global economic downturn; allowing for greater policy interest rate and exchange rate flexibility; and implementing a sweeping set of reforms of the business environment that that has placed Rwanda among the top reformers in the World Bank's Doing Business Index in 2010 and 2011. Notwithstanding these achievements, the authorities recognize Rwanda's vulnerabilities-low government revenues, a narrow export base, and severe bottlenecks in infrastructure-and have embarked on a program supported by the

\footnotetext{
${ }^{1}$ In August this year, Fitch upgraded Rwanda's sovereign rating by a notch to 'B', citing gains made from a sustained period of strong growth and improvement in the business environment.
} 
Fund's Policy Support Instrument (PSI) aimed at mitigating these vulnerabilities while consolidating gains in macroeconomic stability (Box 2). The authorities' reform agenda is also supported by the World Bank, DFID, and other development partners.

\section{Box 2: Key Objectives of the PSI}

The PSI supports the authorities' program to achieve sustainable broad-based high growth and poverty reduction, in line with their Economic Development and Poverty Reduction Strategy (EDPRS), while maintaining macroeconomic stability. Consistent with these objectives, the program aims to:

- $\quad$ Maintain a sustainable fiscal position, with increasing mobilizing domestic revenues aimed at reducing Rwanda's aid dependency;

- $\quad$ Strengthen monetary and exchange rate policies to ensure low and stable inflation;

- $\quad$ Reduce financial sector vulnerabilities by strengthening banking supervision, and deepening the financial sector by enhancing access to credit; and

- Underpin growth with structural reforms to diversify the export base and improve the business environment.

\section{RECENT DEVELOPMENTS}

\section{Rwanda's economy is showing clear signs of recovery from the external and} domestic shocks of the past two years, while inflation has remained low (Table 2 and Figure 1). After slowing to 4.1 percent in 2009 from 11.2 percent in 2008, real GDP growth for 2010 is expected to reach 6.5 percent, driven by a rebound in exports and stronger-thanexpected growth in services (mainly in telecommunications) and construction-sectors that were adversely affected by the global recession and tight domestic liquidity. High-frequency macroeconomic indicators for the first three quarters of 2010 support the pickup in economic activity (Figure 2). For the first time in many years, annual inflation has remained below 5 percent in 2010, reflecting in large part the benign external environment, especially stable food and fuel prices. Higher export performance, reflecting a rebound in international prices and stronger-than-expected volumes of coffee, tea, and non-traditional exports, has contributed to a narrowing of the external current account deficit (excluding grants) to 17.3 percent of GDP in 2010, from 18.6 percent in 2009, while international reserves remain at comfortable levels (Table 3 and Figure 3).

4. Fiscal performance in FY 2009/10 was better than projected. ${ }^{2}$ Domestic revenue collection exceeded the indicative target for the PSI during January-June 2010, mainly on

\footnotetext{
${ }^{2}$ Fiscal year runs from July to June.
} 
account of taxes on goods and services and direct taxes (Table 4 and Figure 4). Overall spending in the second half of the fiscal year was in line with the PSI program, as overruns in current expenditures, namely goods and services, were offset by lower-than-expected net lending. ${ }^{3}$

\section{Monetary policy has been accommodative, but private sector credit has been}

slow to respond. Despite three cuts in the central bank's policy rate (the key repo rate) since November 2009 by a cumulative 300 basis points ${ }^{4}$, commercial banks' lending rates have remained persistently high, while they continue to maintain a cautious credit stance. Credit to the private sector has rebounded from the low levels in 2009, but the pace is much slower than envisaged in the program for 2010 (Table 5 and Figure 5). Non-performing loans and loan loss provisions have continued to edge down in 2010 (Table 6 and Figure 6).

\section{With the introduction of the interbank exchange rate corridor framework in} March 2010, the Rwandan franc has begun to move in line with macroeconomic fundamentals. The franc depreciated by 2.5 percent against the US dollar between April and October 2010, a larger movement than observed in 2009 as a whole. The depreciation of the franc against the US dollar reflected the strengthening of the dollar against the major international currencies (euro and pound sterling) over the first three quarters of 2010, similar to the depreciations of other EAC currencies against the US dollar in the period.

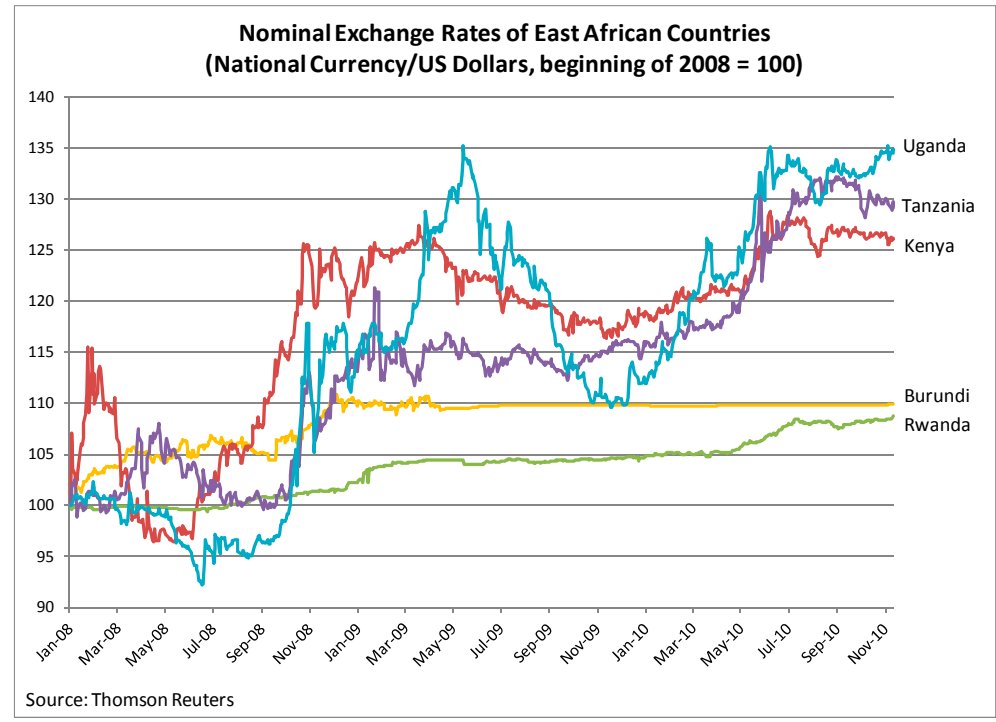

\footnotetext{
${ }^{3}$ Lower revenues and delays in grants during the first quarter of 2010/11 (July - September 2010) contributed to temporary build up in arrears ( $\mathrm{Rwf} 7$ billion, equivalent to 0.2 percent of GDP), despite lower-thanprogrammed spending.

${ }^{4}$ The central bank also lowered its reserve requirements from 8 to 5 percent in February 2009.
} 
Figure 1. Rwanda: Recent Performance, Achievements, and Challenges

Real GDP growth has begun to recover in $2010 \ldots$

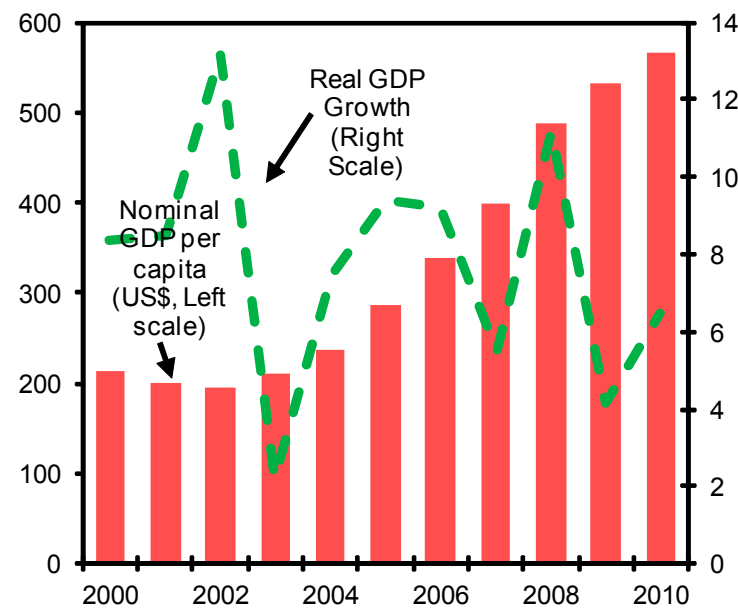

Inflation seems to have stabilized in single digits while gross international reserves remain

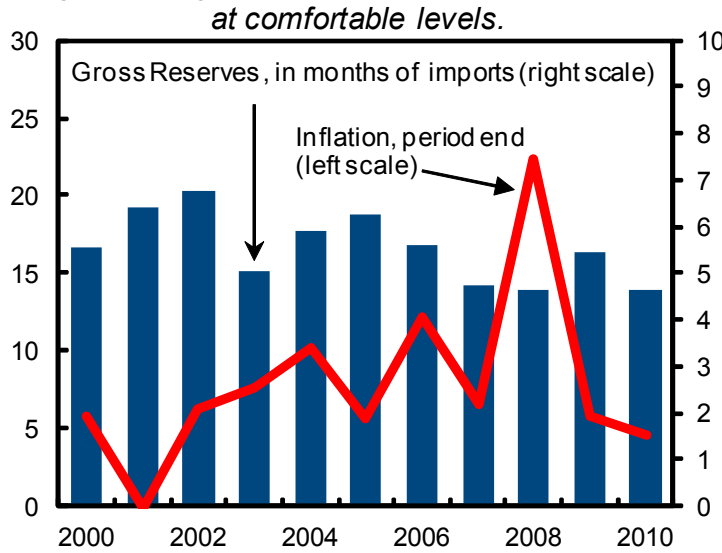

Rwanda remains a poor country...

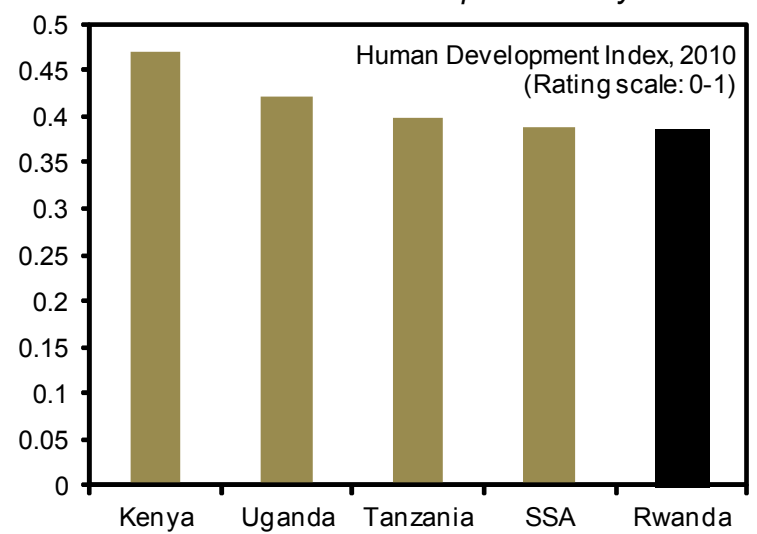

... driven by the primary and tertiary sectors.

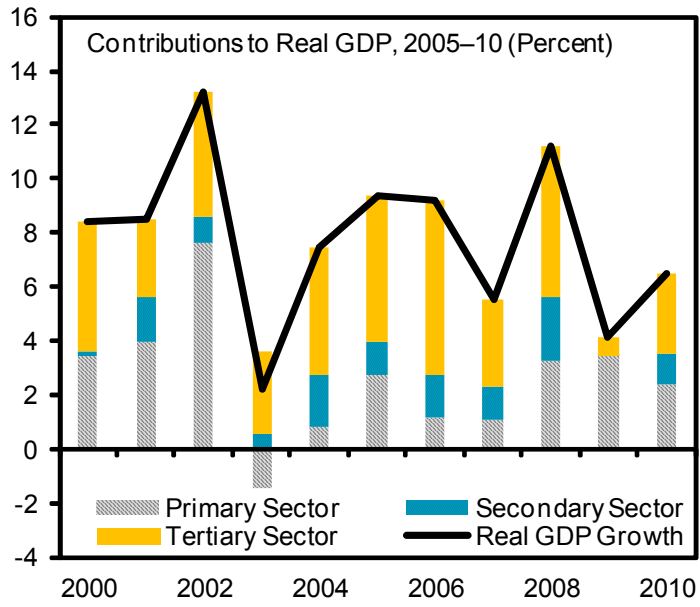

However, a narrow export base has contributed to a large trade deficit.

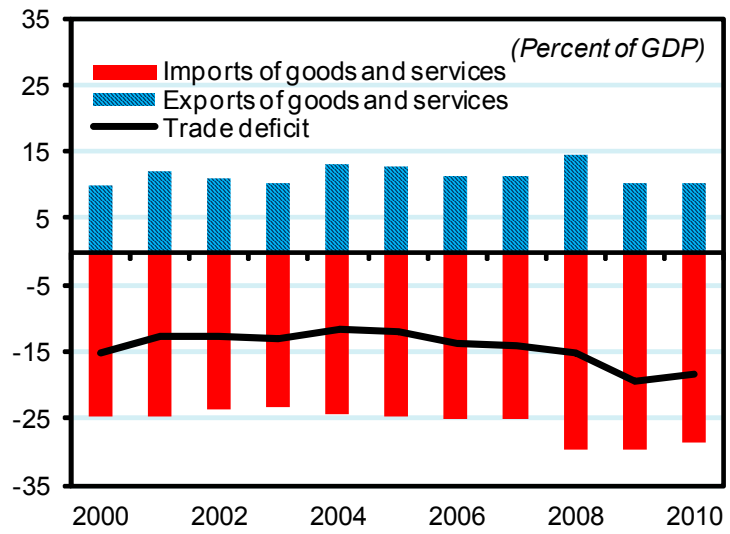

...that continues to depend on aid.

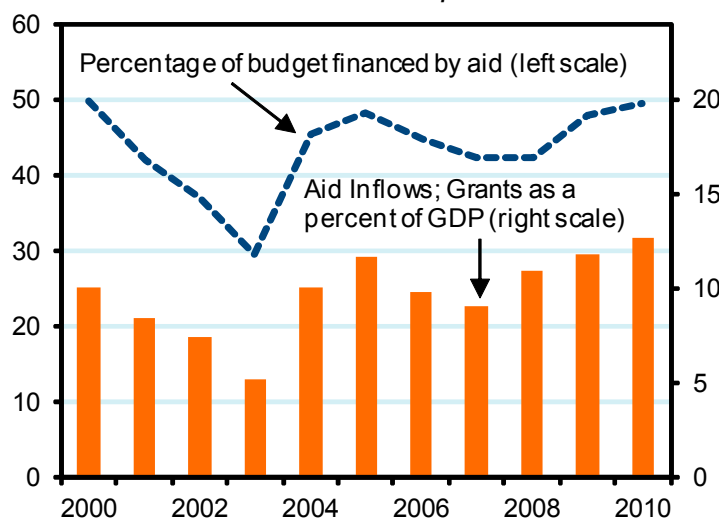

Sources: Rwandan authorities, IMF staff estimates, World Economic Outlook, AFR's Regional Economic Outlook and UNDP Human Development and Poverty Indicators. 
Figure 2. Rwan da: Selected High Frequency In dicators of Economic Activity, Jan 2006-Sep 2010
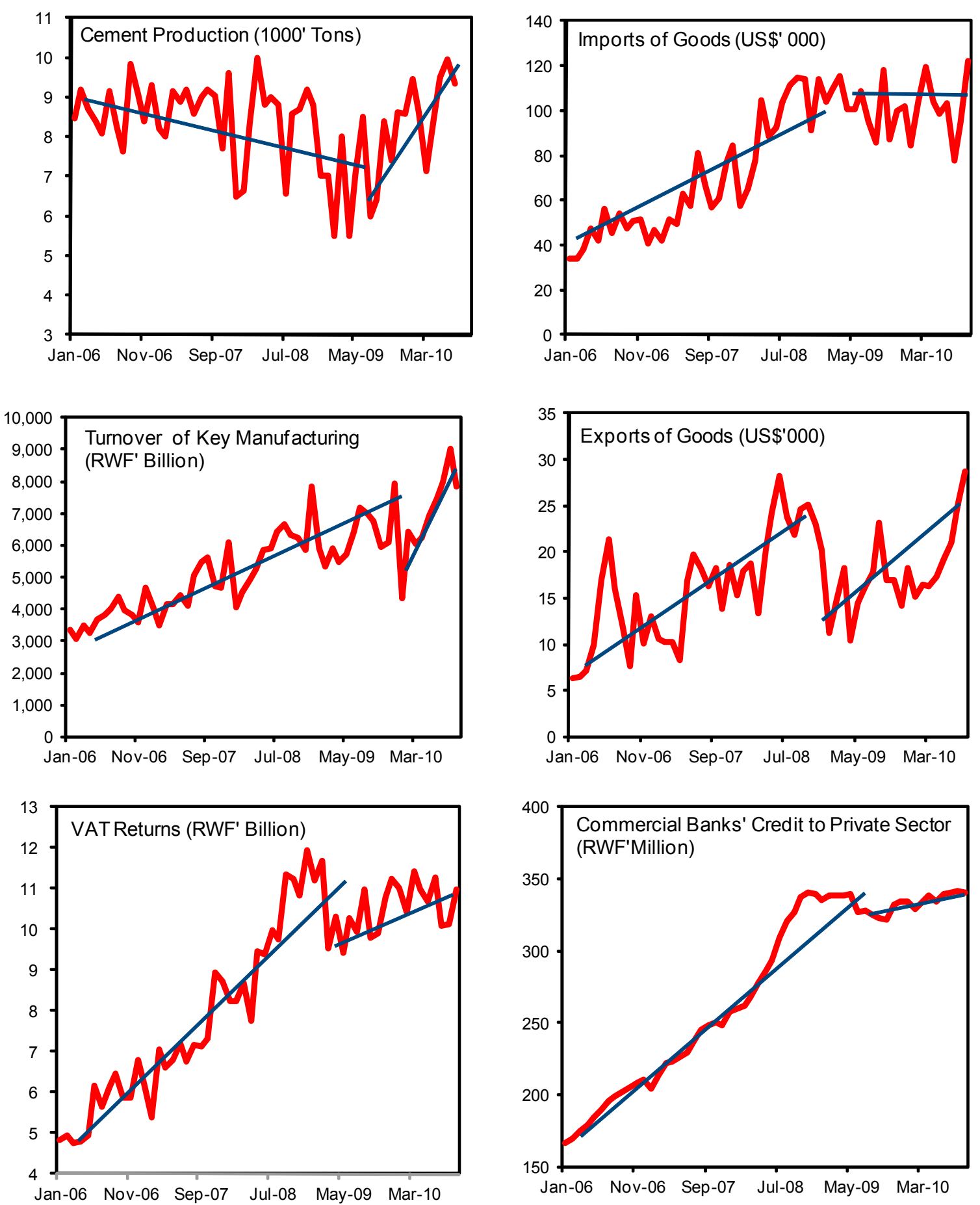

Sources: IMF staff and Rwandan authorities estimates. 
Figure 3. Rwanda: External Developments, 2005-10

Coffee and tea exports rebounded in 2010, while tourism performed below expectations and mineral exports were flat in spite of higher prices.

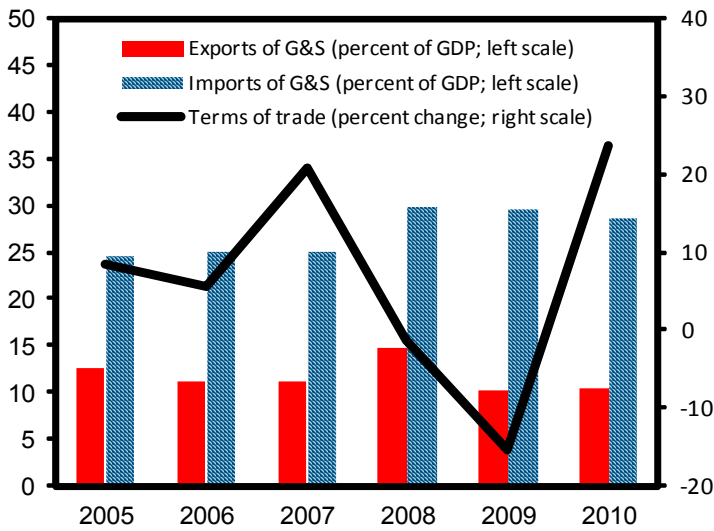

... in part because of higher transfers, especially from continuing strong donor support.

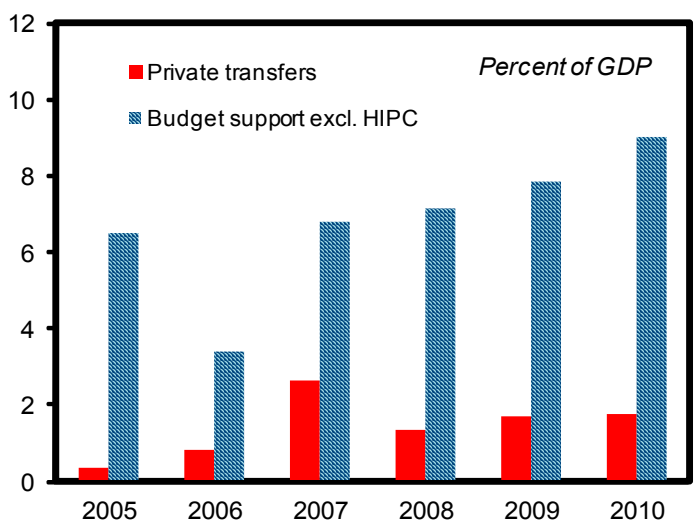

The overall reserves position would remain at comfortable levels.

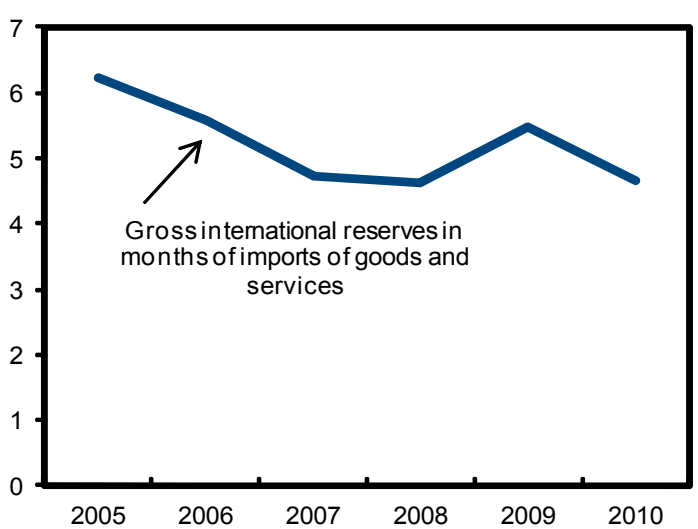

The current account deficit narrowed in $2010, \ldots$

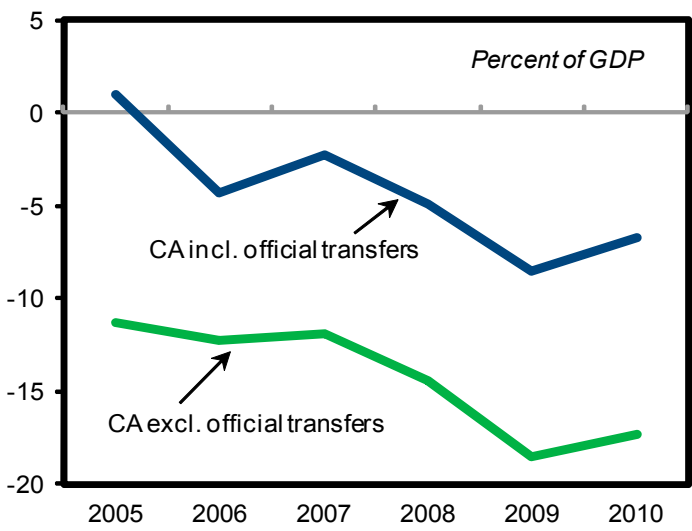

Foreign direct investment is expected to be lower in 2010, mainly because a few large investment deals are still being firmed up.

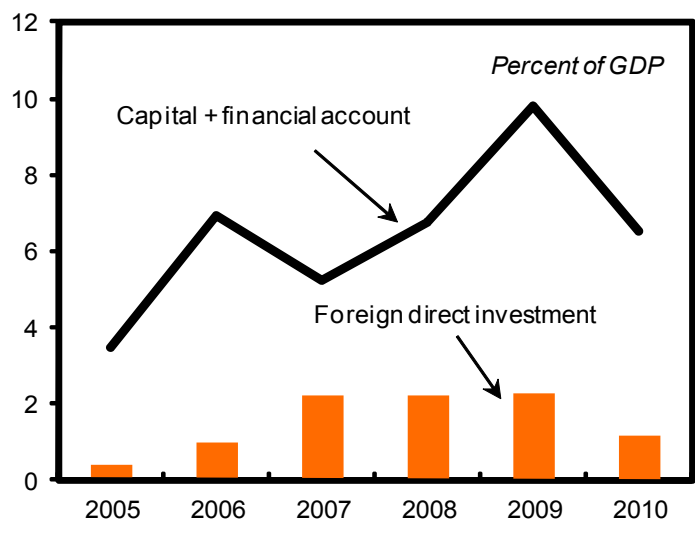

The exchange rate has depreciated somewhat, confirming the central bank's commitment to allow more flexibility.

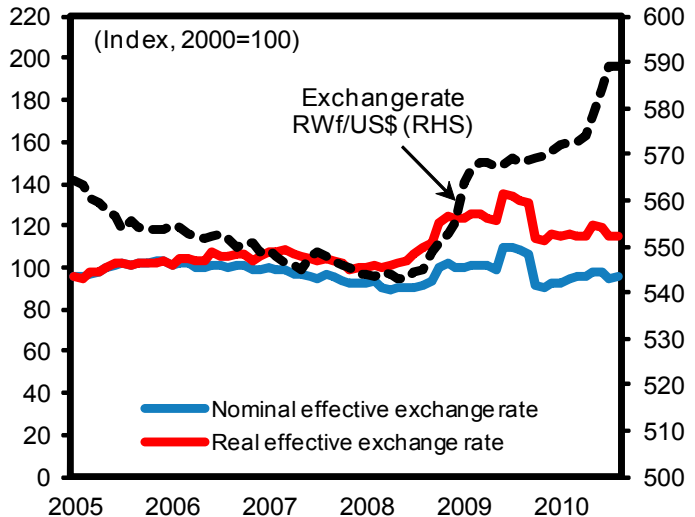

Sources: IMF staff and Rwandan authorities estimates. 
Figure 4. Rwanda: Fiscal Developments, 2005-10

The fiscal deficit widened on account of rising spending to mitigate the downturn...

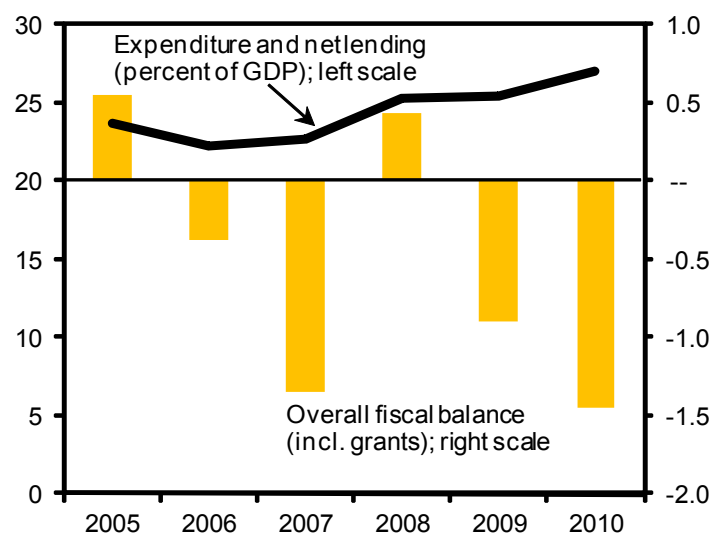

Priority spending increased in line with EDPRS priorities...

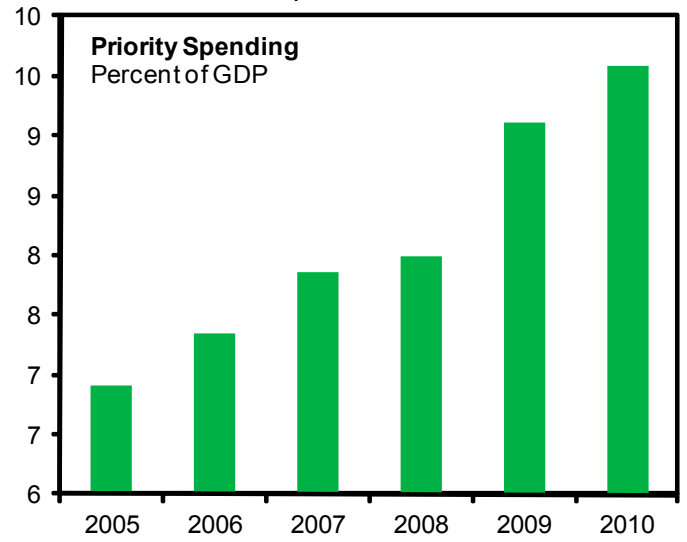

External debt is at low levels, thanks to substantial debt relief, ...

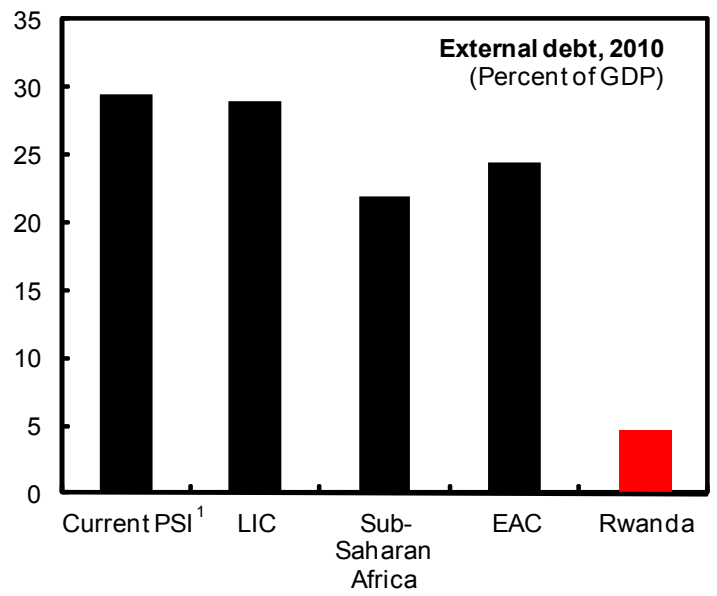

...as well as lower domestic revenues, while donor support remained strong.

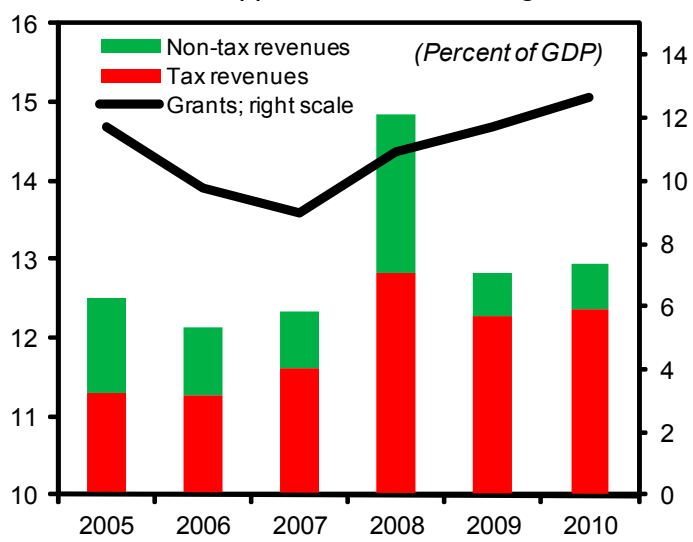

...while capital spending outpaced current spending by significant margins.

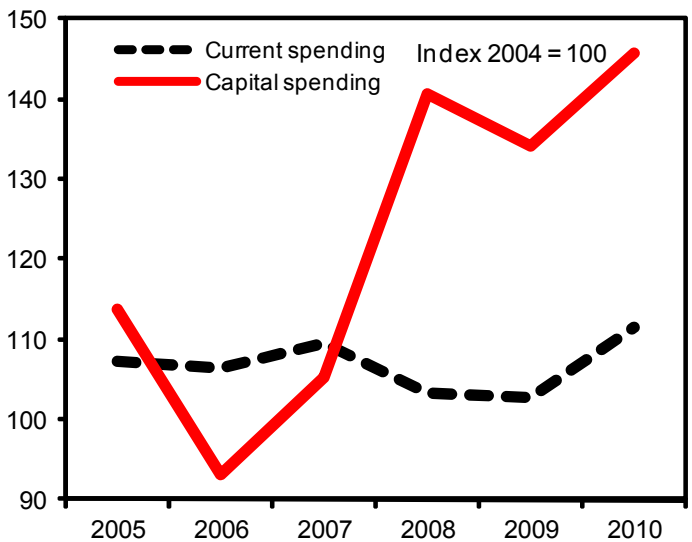

... while low domestic revenues remain a source of vulnerability.

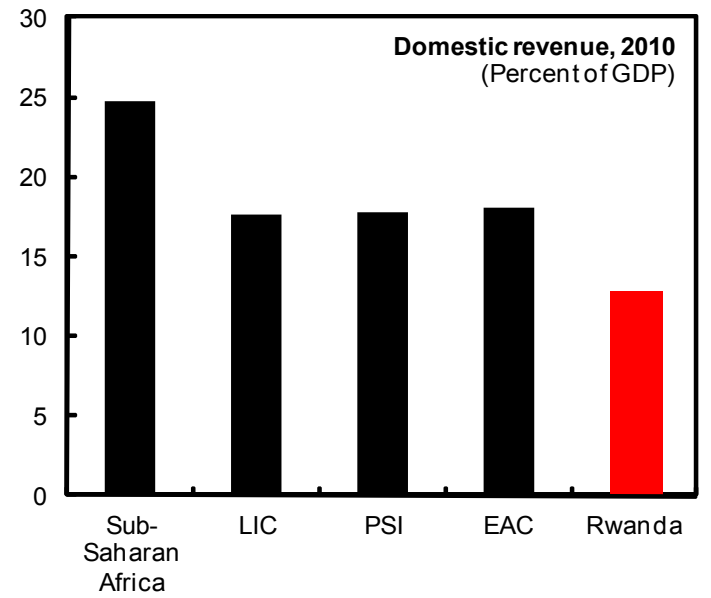

${ }^{1}$ Current PSI countries are: Cape Verde, Mozambique, Senegal, Tanzania, and Uganda.

Sources: IMF staff and Rwandan authorities estimates. 
Figure 5. Rwanda: Monetary and Financial Developments, 2004-10

NFA control has improved over the last year...

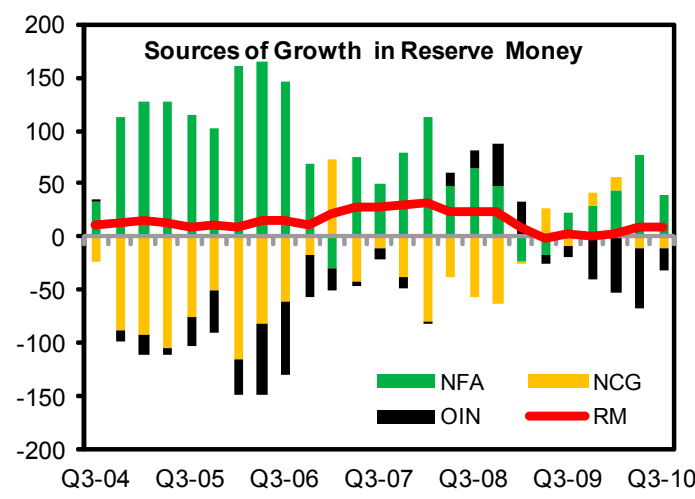

Real interest rates have remained positive

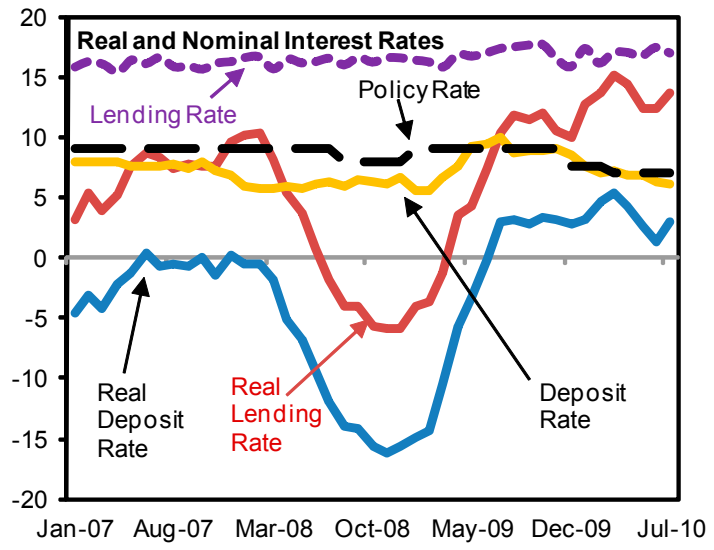

....and a gradual turnaorund in credit to the private sector in $2010 \ldots$

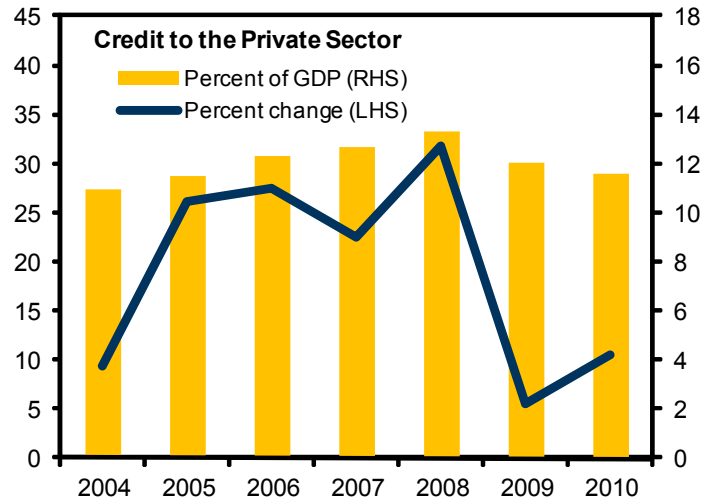

Sources: Rwandan authorities and IMF staff estimates.
... reflecting improved control of reserve money.

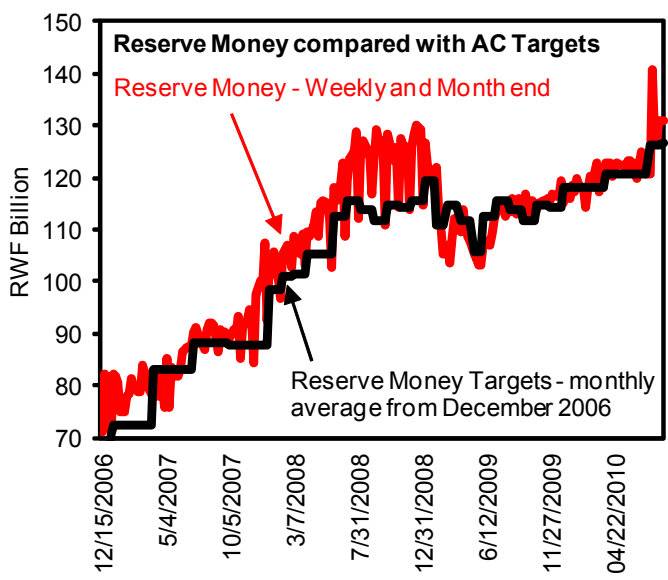

... leading to build-up of liquidity in the banking system ...

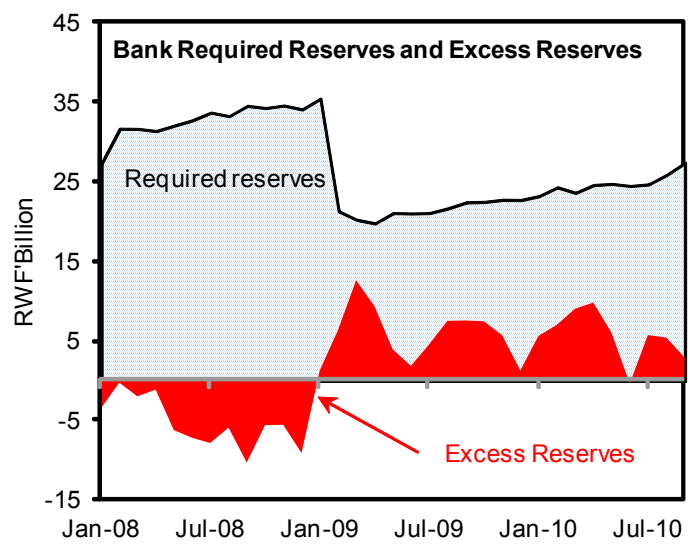

... underpinned by improving banking stability conditions.

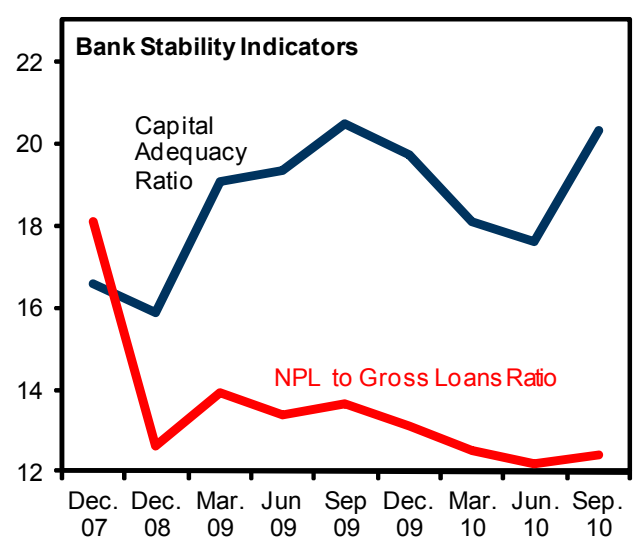


Figure 6. Rwanda: Developments in the Financial Sector, 2003-Sep. 2010

The banking system remains well capitalized...

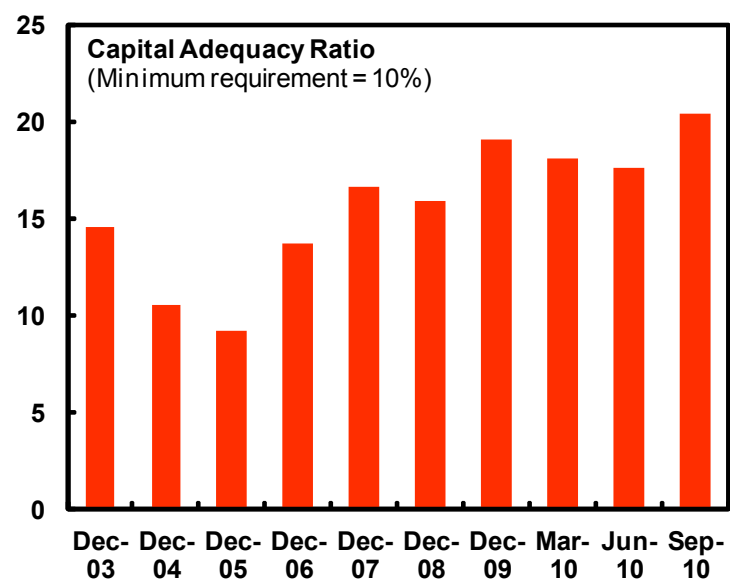

Non-performing loans have remained sticky downwards...

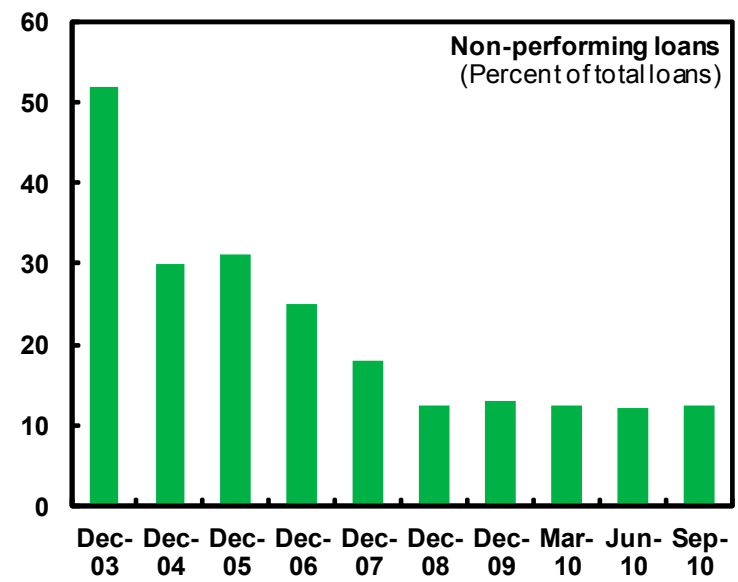

The pace of financial deepening has begun to slow down...

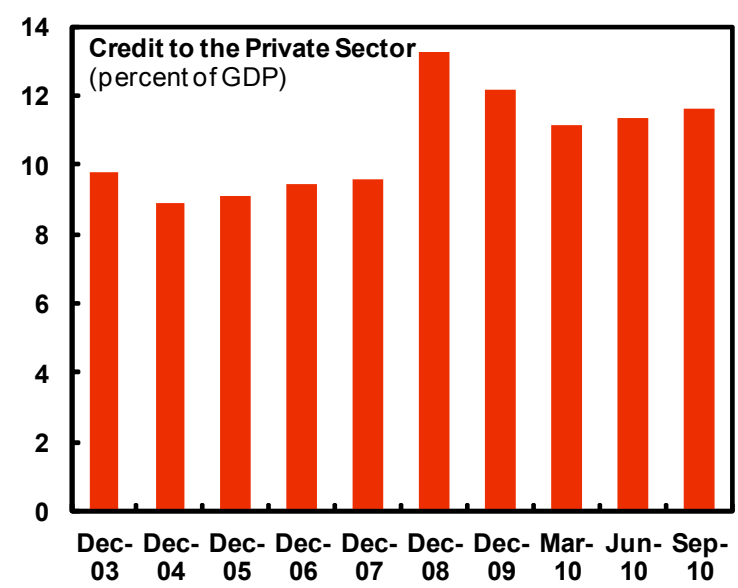

... and banks' loans remain highly concentrated.

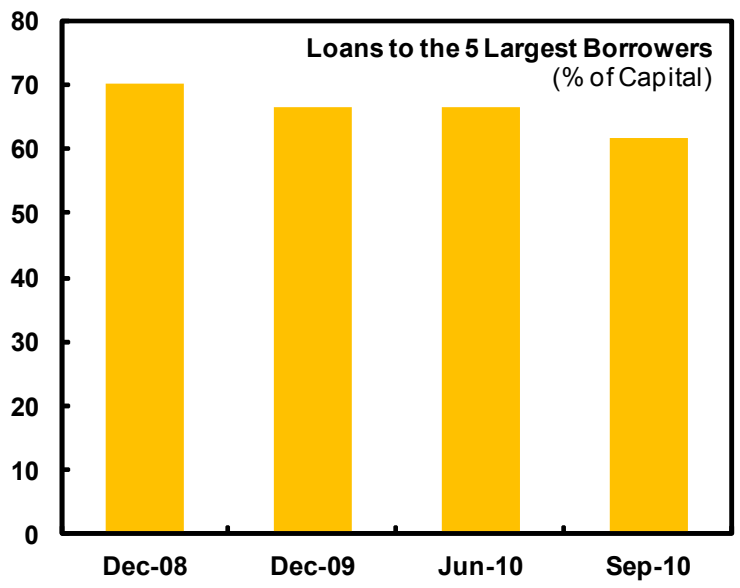

...resulting in relatively short asset maturity.

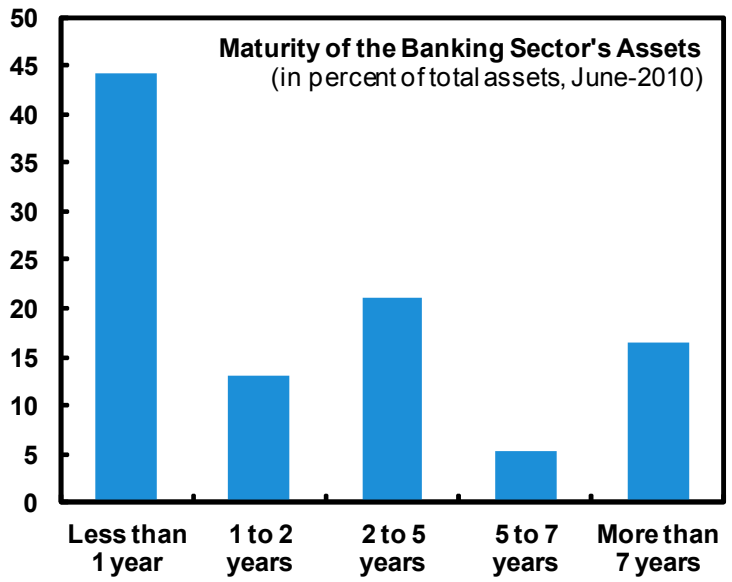

... in part due to obstacles to access to credit.

\begin{tabular}{|c|c|c|c|}
\hline \multicolumn{4}{|c|}{ Access to Credit } \\
\hline & Rwanda & $\begin{array}{c}\text { Sub- } \\
\text { Saharan } \\
\text { Africa }\end{array}$ & $\begin{array}{l}\text { OECD } \\
\text { Average }\end{array}$ \\
\hline $\begin{array}{l}\text { Rank } \\
\text { (out of 183) }\end{array}$ & 61 & $\cdots$ & $\ldots$ \\
\hline $\begin{array}{l}\text { Strength of legal rights } \\
\text { index }(0-10)\end{array}$ & 8 & 4.6 & 6.8 \\
\hline $\begin{array}{l}\text { Depth of credit information } \\
\text { index }(0-6)\end{array}$ & 2 & 1.5 & 4.9 \\
\hline $\begin{array}{l}\text { Public registry coverage } \\
\text { (\% of adults) }\end{array}$ & 0.4 & 2.4 & 8.8 \\
\hline $\begin{array}{l}\text { Private bureau coverage } \\
\text { (\% of adults) }\end{array}$ & 0 & 4.5 & 59.6 \\
\hline
\end{tabular}

Sources: Rwandan authorities, World Bank Doing Business (2011) and IMF staff estimates. 
7. As of 2009/10 Rwanda has a better track record than other EAC in meeting the EAC convergence criteria. Among the four EAC criteria, only the overall balance (excl. grants) was not met due to historically high levels of donor flows designed to mitigate the impact of the global economic downturn.

EAC Convergence Criteria (2009/10)

\begin{tabular}{|c|c|c|c|c|c|c|c|}
\hline & Stage 1 & Stage 2 & Burundi ${ }^{1}$ & Kenya & Rwanda $^{2}$ & Tanzania & Uganda \\
\hline $\begin{array}{l}\text { Overall fiscal deficit (excl. grants) } \\
\text { percent of GDP }\end{array}$ & $<6 \%$ & $<5 \%$ & 20.7 & 7.4 & 13.2 & 11.2 & 7.4 \\
\hline $\begin{array}{l}\text { Overall fiscal deficit (incl. grants) } \\
\text { percent of GDP }\end{array}$ & $<3 \%$ & $<2 \%$ & 5.2 & 6.5 & 0.1 & 6.5 & 4.9 \\
\hline $\begin{array}{l}\text { Inflation, period average } \\
\text { percent per annum }\end{array}$ & $<5 \%$ & $<5 \%$ & 10.7 & 2.4 & 3.2 & 10.5 & 9.4 \\
\hline $\begin{array}{l}\text { Foreign exchange reserves } \\
\text { in months of imports }\end{array}$ & $>4$ & $>6$ & 6.5 & 3.4 & 4.6 & 5.1 & 4.6 \\
\hline
\end{tabular}

Source: Rw andan authorities and IMF staff calculations.

${ }^{1}$ For Burundi, data are calender year 2010.

${ }^{2}$ For Rw anda, inflation and foreign exchange reserves are calender year 2010.

\section{Program Performance}

8. Performance under the PSI has been satisfactory.

- All quantitative assessment criteria and structural benchmarks under the PSI program for end-June 2010 were met (MEFP Tables 1 and 2). The indicative target on domestic debt of the public sector was missed at end-June, as the government had to issue Treasury bills to ease its tight cash flow due to late donor disbursements. The debt is expected to be repaid soon as donor funds have already been disbursed.

- Structural reforms are broadly on track. Notably, public financial management has continued to improve with the rollout of core modules of the Integrated Financial Management Information System (IFMIS/Smartgov) to 94 agencies, while revenue administration has been strengthened with the Rwanda Revenue Authority (RRA) taking over the collection and audit functions of social security contributions. The National Bank of Rwanda (NBR) has enhanced the effectiveness of monetary policy, in particular by holding frequent meetings of the Monetary Policy Committee (MPC), backed by an improved communication strategy. Also at the NBR, an exchange rate corridor framework was introduced as a transition measure toward greater exchange rate flexibility. All structural benchmarks for July-September were met except for the submission of an export diversification strategy to Cabinet. Although the draft export strategy was available by the August benchmark date, it will be submitted to Cabinet by end-January, pending incorporation of review by stakeholders. The authorities are on track to meet most of the end-December 2010 structural benchmarks. The 
submission to Cabinet of the medium-term debt strategy is now planned for endJanuary 2011 (originally planned for end-December 2010) owing to delays in hiring consultants to assist with the strategy.

\section{Policy Discussions: MaInTAINING MaCroeconomic STABILITY WhILE Boosting GROWTH AND COMPETITIVENESS}

\section{A. Outlook and Risks}

9. The economic outlook is favorable (Figure 7). Real GDP growth is projected at $61 / 2-7$ percent in 2011-12, similar to the outlook in the region and higher than the growth projections for Sub-Saharan Africa as a whole. Medium-term growth will be driven by: (i) the government's strategic investments, supported by a more business-friendly environment;

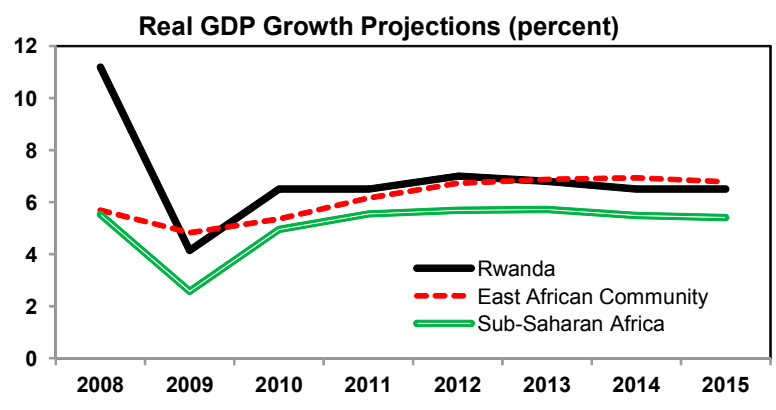
(ii) recovery in external demand; and (iii) a pick-up in credit to the private sector. The outlook assumes a conservative implementation of the government's investment strategy, in view of the timing needed to secure the necessary financing. ${ }^{5}$ With the onset of recovery, inflation is expected to pick up to 6 percent in 2011 from the exceptionally low levels recorded in 2010, but should stabilize at 5 percent over the medium term, in line with projected inflation in the region. The current account deficit in the near term is expected to widen to 9 percent in 2011 due to higher imports for large investment projects, but is projected to narrow down to about 4 percent over the medium-term.

10. Rwanda's economy has potential for higher growth. Staff analysis shows that Rwanda's economy could potentially grow at about $8 \frac{1}{2}$ percent over the medium term, provided that (i) investment is scaled up significantly; (ii) productivity growth increases and remains elevated; and (iii) there are no adverse shocks. ${ }^{6}$ Achieving and maintaining this high growth rate, however, is challenging and will require additional investments of some US\$200-400 million (or about 4-8 percent of GDP) annually over the medium-term, beyond assumed investments in the baseline projections (Box 3).

\footnotetext{
${ }^{5}$ Following some delays in 2010 in securing external financing, both FDI and external borrowing, the government's large investment projects (namely Rwandair, Kigali Convention Center, etc.) are expected to pick up in 2011 once the external financing is secured. Thereafter capital spending as a share of GDP is projected to return to trend levels.

${ }^{6}$ See Appendix II.
} 


\section{Risks to the outlook are on the downside, reflecting mainly slower pickup in} external demand and domestic credit. Donor flows are expected to remain strong, but decline gradually over the medium term. Over the longer term, risks to potential growth include lower levels of investment financing and smaller productivity gains than envisaged in staff's estimation of potential growth. There are also upside risks to inflation from higher global food and fuel prices.

\section{Authorities'Views}

\section{The authorities broadly agreed with staff's views on the economic outlook,} although they viewed growth prospects as stronger, with low and manageable risks. They noted that they expect growth in 2010 and 2011 to be higher than 7 percent, underpinned by a much higher turn around in construction and services than projected by staff. Looking ahead, they expect growth to accelerate at a faster pace, reaching 8 percent per annum by 2014 , just below the potential growth estimated by staff. The authorities' higher growth path is premised on fully securing the necessary financing, including by crowding in the private sector, to implement their strategic investments.

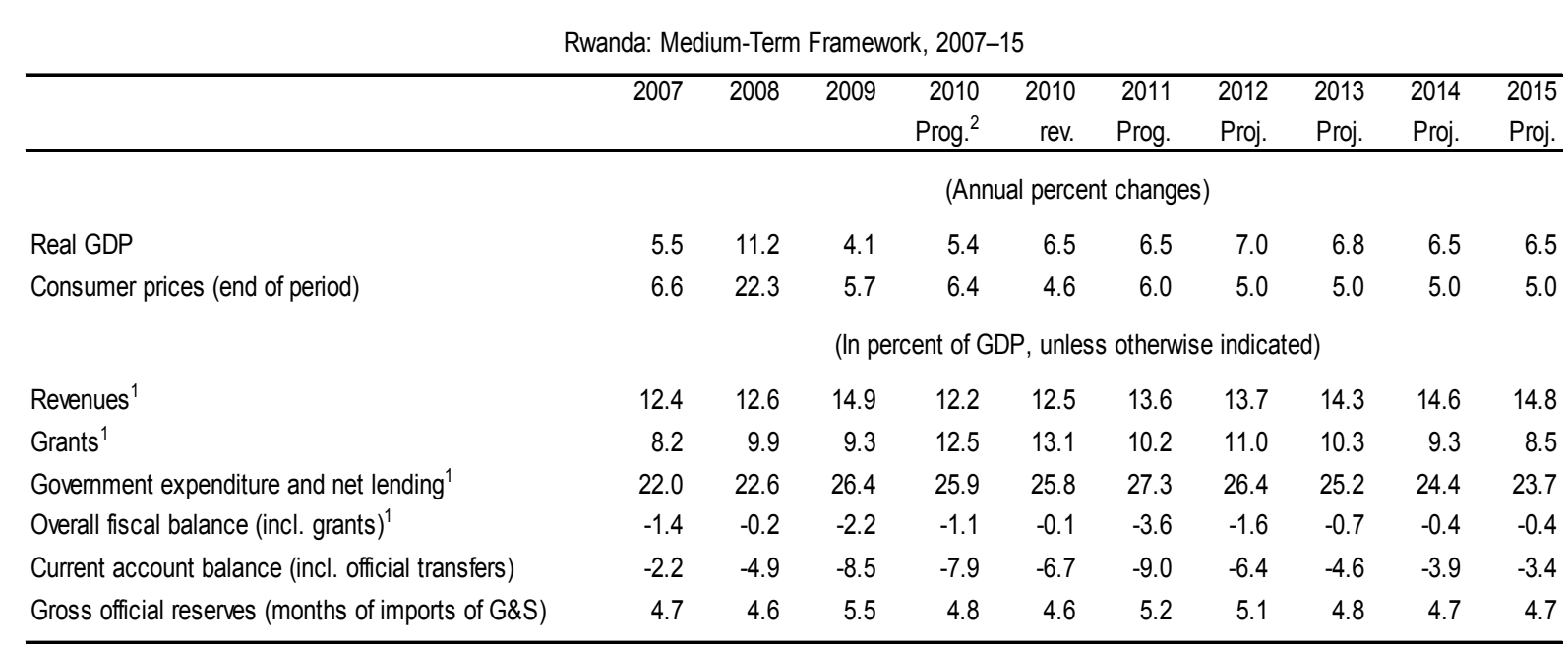

${ }^{1}$ On a fiscal year basis (July-June). For example, the column ending in 2011 refer to FY2010/11 fiscal data. Other data are on a calendar year basis. Sources: Rwandan authorities and IMF staff estimates and projections.

2 IMF Country Report No. 10/200. 
Figure 7. Rwanda: Medium-Term Outlook¹, 2008-15

GDP growth is projected to return gradually to the trend growth...

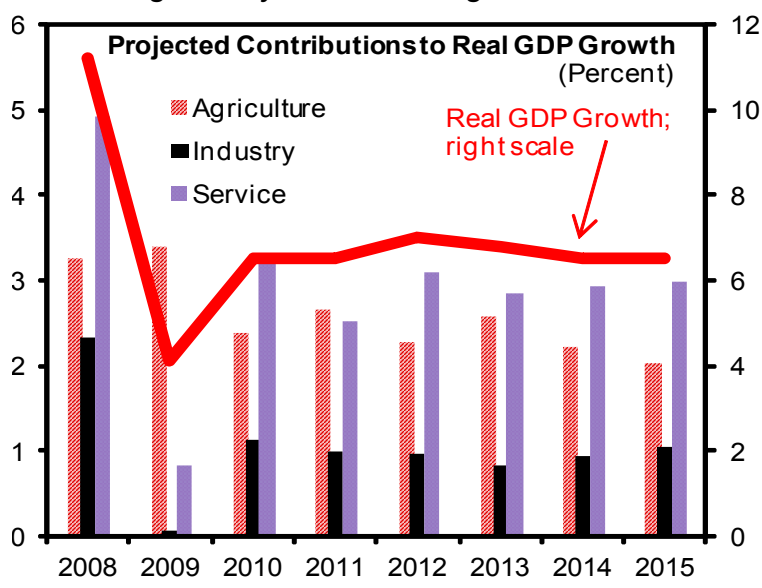

The external current account is expected to improve...
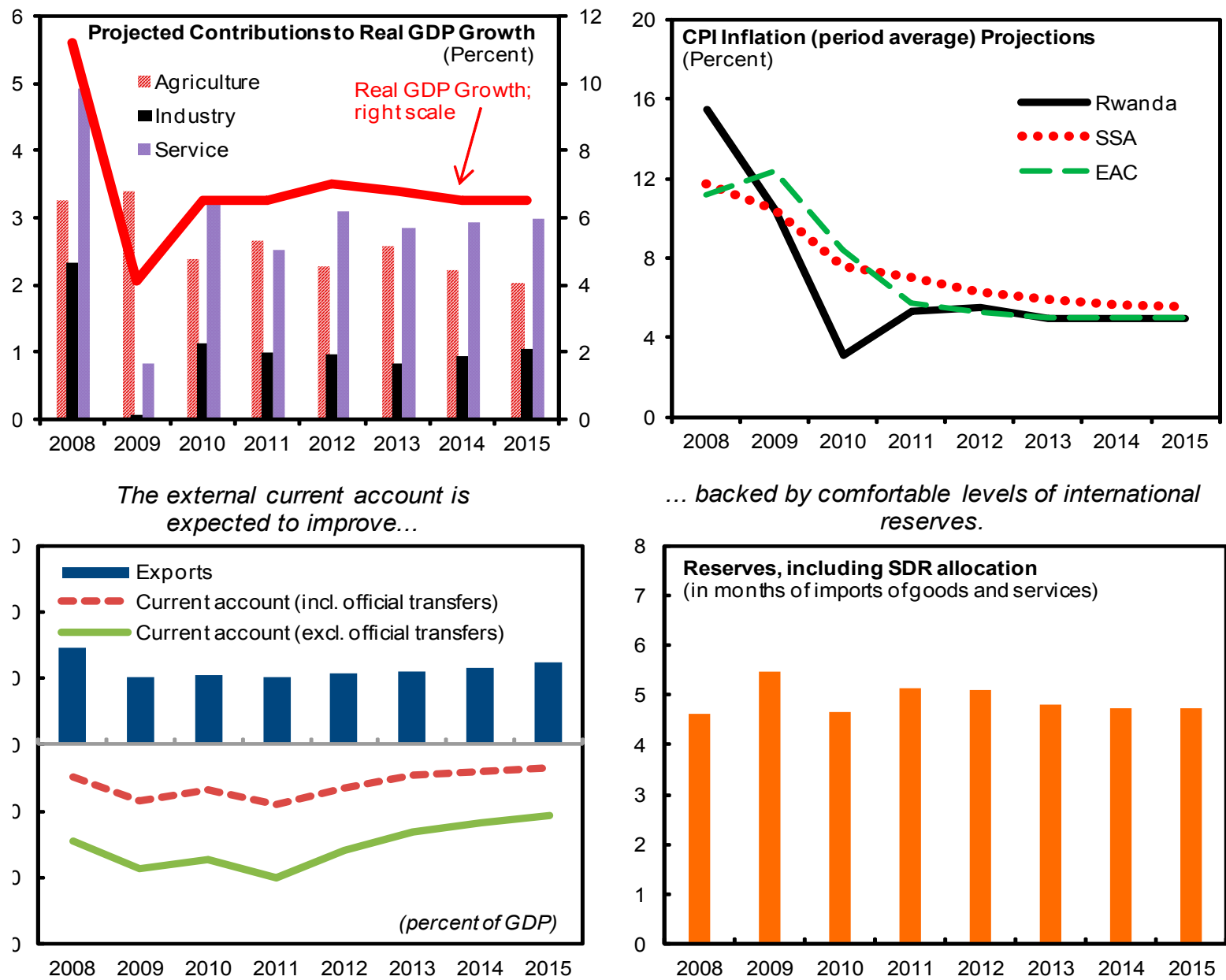

... backed by comfortable levels of international reserves.

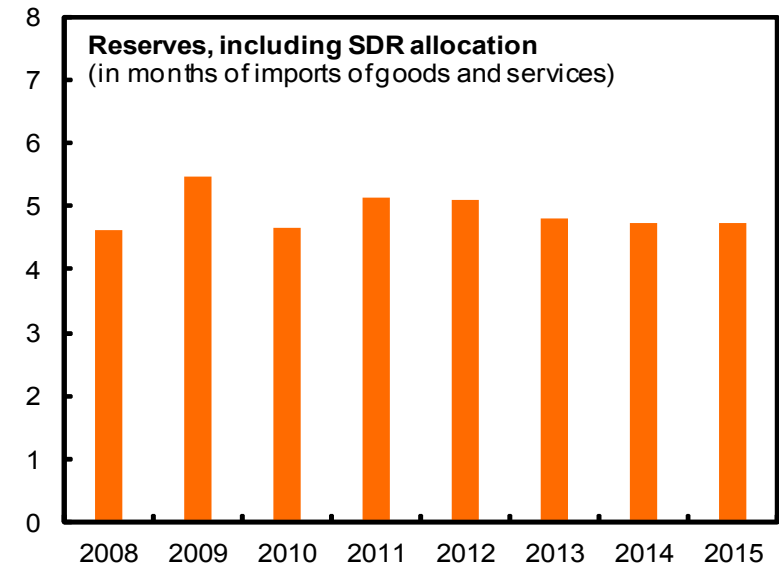

Gradual unwinding of fiscal stimulus...

... is supported by higher domestic revenues and expenditure rationalization.
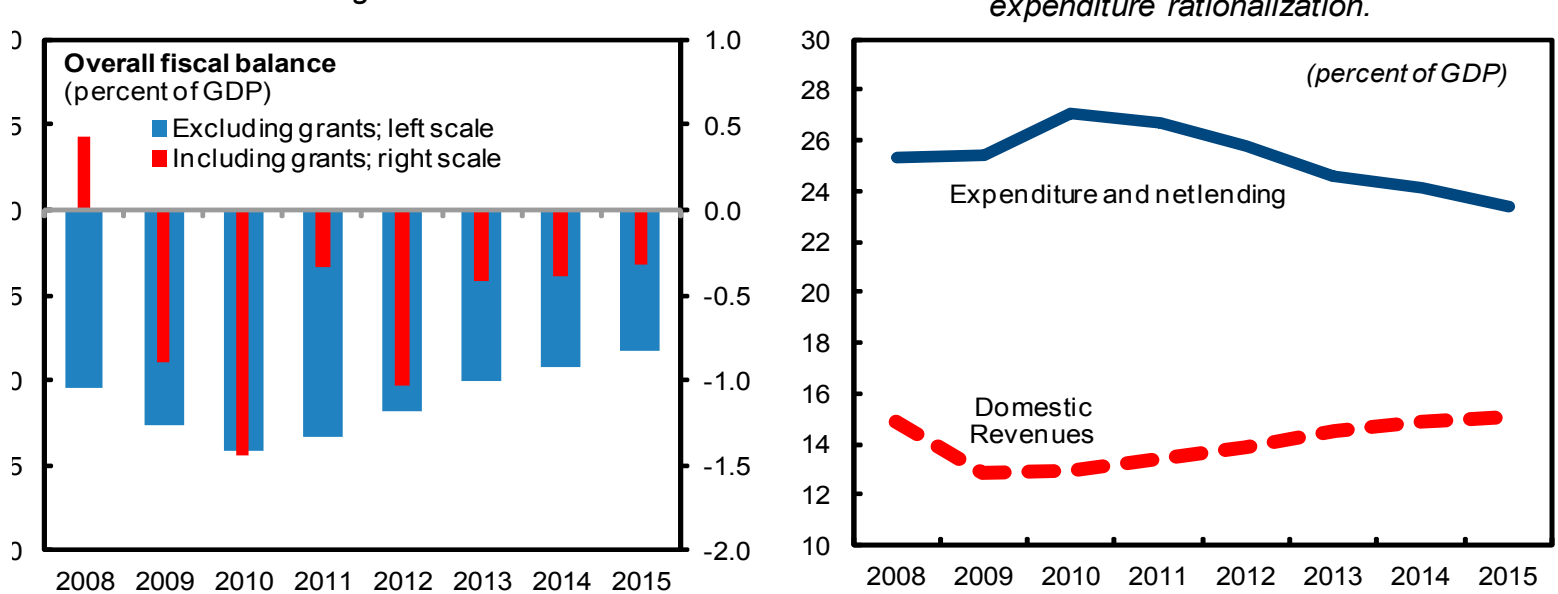

Sources: IMF staff and Rwandan authorities estimates.

${ }^{1}$ Fiscal numbers are on calender year basis. 


\section{Box 3. Sources of Rwanda's Economic Growth ${ }^{1}$}

A substantial part of Rwanda's impressive economic growth of 8 percent a year over the past decade can be explained by productivity gains. $^{2}$ The contribution of productivity to output growth outpaced that of neighboring countries such as Kenya and Uganda. Rwanda's economic recovery in 2010, to an estimated 6.5 percent real GDP growth from 4.1 percent growth in 2009, is supported by a 1.3 percent gain in productivity. The productivity gain in 2010 was a rebound from the sharp decline in 2009 , caused by the domestic liquidity crisis and the global financial turmoil.

\section{Over the medium term, staff's baseline} projections show economic growth stabilizing at around 6.5 percent. The projection assumes a conservative implementation of the government's strategic investments, and continued gains in productivity (productivity gains peak at 2.2 percent in 2015 in the baseline).
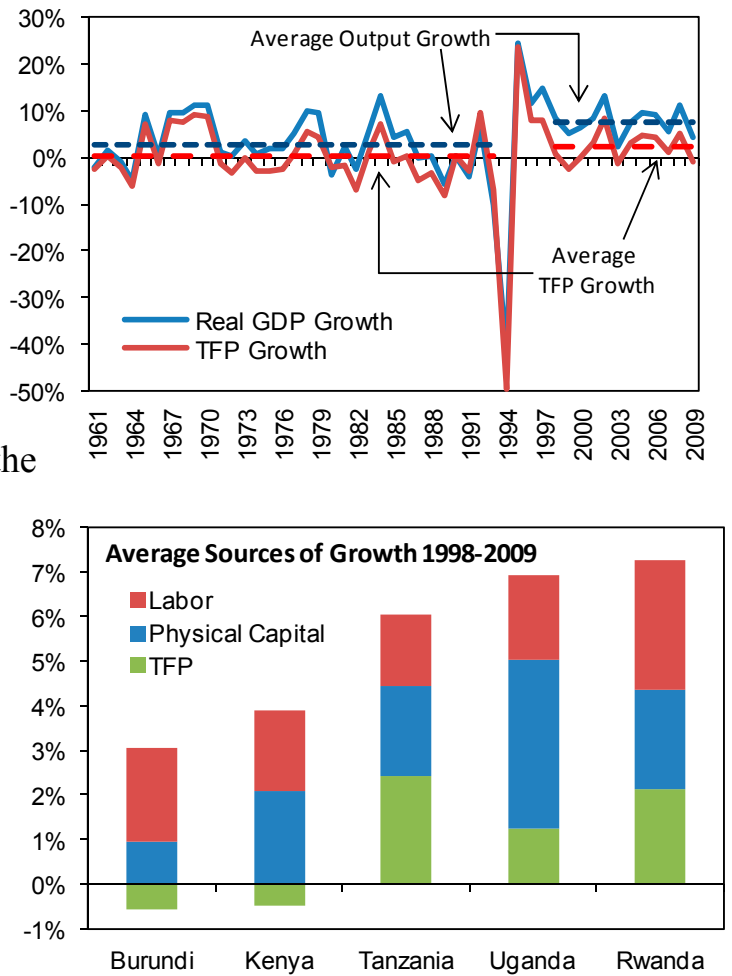

There is potential for higher growth in Rwanda. The economy could potentially grow by 8.4 percent per annum, under a best case scenario of significantly higher private investment in response to an enhanced business environment, and even higher productivity gains. Productivity gains would have to reach close to 3 percent by 2015 to achieve the higher growth. The best case scenario also assumes no adverse shocks.
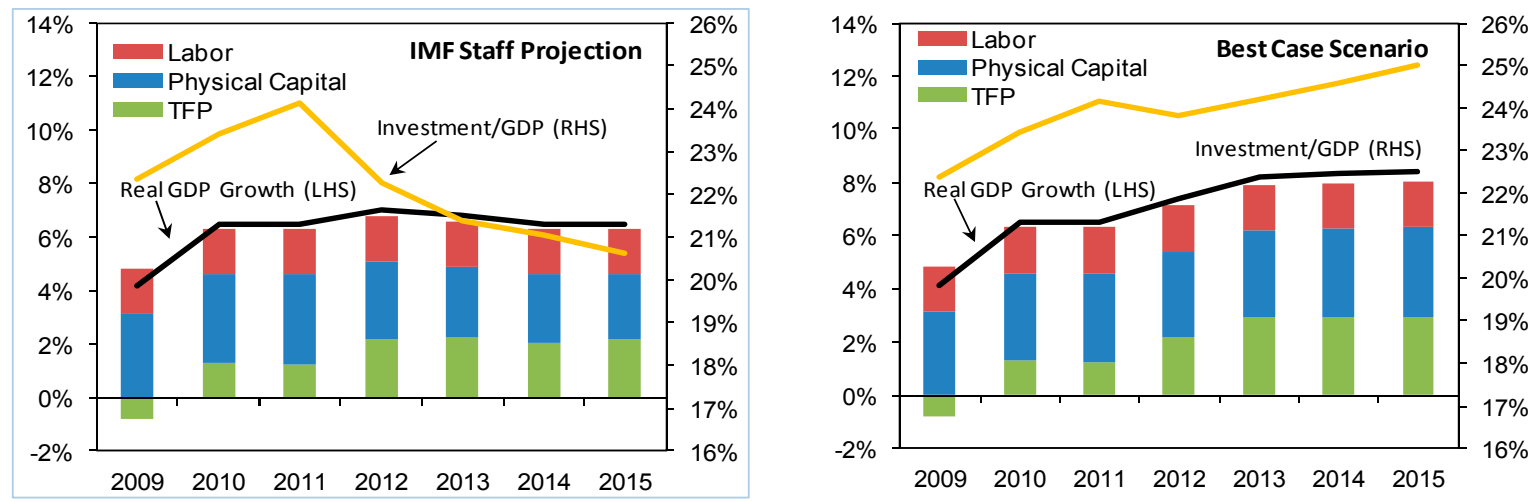

\footnotetext{
${ }^{1}$ See Appendix II "Rwanda-Sources of Growth Using a Growth Accounting Framework" for details.

${ }^{2}$ It should be noted that the high productivity gains since 1998 reflect the strong rebound from the conflict in 1994, which is a characteristic of many post-conflict countries.
} 


\section{Staff and the authorities agreed that policy implementation should ensure} Rwanda emerge successfully from the global economic downturn. Although the economy has rebounded, the recovery is still fragile and the global financial crisis may have set back Rwanda's progress in MDGs. The government has set ambitious objectives in a number of areas-including sustaining 7-8 percent annual real GDP growth and achieving middleincome status by 2020 - through removing infrastructure bottlenecks, raising agricultural productivity, pursuing labor intensive growth, and deepening financial markets. The authorities have prepared a preliminary progress report on their Economic Development and Poverty Reduction Strategy (EDPRS) ${ }^{7}$ which shows some progress in social sectors, including in education and skills development. However, they also point to binding constraints such as low investment in key sectors, lack of statistical data for monitoring and evaluation, and absence of a social protection strategy as hindering further progress in EDPRS and MDGs.

14. Accordingly, the authorities are implementing policies in several areas to firm up the recovery in the short run and consolidate growth at a higher path over the medium term. Policy discussions therefore focused on the following areas:

- Unwinding Fiscal Stimulus Gradually

- $\quad$ Mapping an Effective Monetary and Exchange Rate Policy

- $\quad$ Strengthening Financial Stability while Deepening Financial Markets

- $\quad$ Boosting Competiveness and Growth

\section{B. Unwinding Fiscal Stimulus Gradually}

15. Following a large fiscal stimulus in $\mathbf{2 0 0 9 / 1 0}$, fiscal policy remains somewhat expansionary in FY 2010/11 to support the nascent recovery, with gradual fiscal consolidation planned thereafter. After imparting a stimulus of about 2 percent of GDP which increased the overall deficit (excl. grants) to 13.2 percent of GDP in 2009/10, the overall deficit (excl. grants) in FY 2010/11 widens somewhat to 13.8 percent of GDP - a fiscal impulse of about $1 / 2$ percent of GDP. The overall fiscal deficit (incl. grants) would widen by $3 \frac{1}{2}$ percent of GDP as external grants decline by an equivalent amount, reverting to pre-crisis levels. ${ }^{8}$

16. To maintain the small fiscal stimulus, spending remains somewhat elevated in 2010/11. Current spending remains unchanged at the 2009/10 level, but the composition of

\footnotetext{
${ }^{7}$ EDPRS covers the 2008-12 periods and was issued to the IMF Board on February 14, 2008. The progress report will be submitted to the IMF Board with the second PSI review.

${ }^{8}$ Donor assistance in the 2009/10 was scaled up in order to mitigate the impact of financial crisis on Rwanda.
} 
total spending is reoriented toward domestic capital investment, including energy, schools construction, and irrigation in agriculture which are expected to have large fiscal multipliers. The higher total spending requires a temporary increase in net domestic financing, given the sizable decline in grants. ${ }^{9}$

Rwanda: Medium-Term Fiscal Framework, 2007/08-2014/15

\begin{tabular}{|c|c|c|c|c|c|c|c|c|c|}
\hline & $2007 / 08$ & $2008 / 09$ & $\begin{array}{r}2009 / 10 \\
\text { Prog. }^{1}\end{array}$ & $\begin{array}{c}\text { 2009/10 } \\
\text { Prel. }\end{array}$ & $\begin{array}{r}2010 / 11 \\
\text { Prog. }\end{array}$ & $\begin{array}{r}2011 / 12 \\
\text { Proj. }\end{array}$ & $\begin{array}{c}2012 / 13 \\
\text { Proj. }\end{array}$ & $\begin{array}{c}2013 / 14 \\
\text { Proj. }\end{array}$ & $\begin{array}{r}2014 / 15 \\
\text { Proj. }\end{array}$ \\
\hline & \multicolumn{9}{|c|}{ (In percent of fiscal year GDP) } \\
\hline Revenue and grants & 22.5 & 24.3 & 24.8 & 25.7 & 23.8 & 24.8 & 24.6 & 23.9 & 23.4 \\
\hline Revenues & 12.6 & 14.9 & 12.2 & 12.5 & 13.6 & 13.7 & 14.3 & 14.6 & 14.8 \\
\hline Grants & 9.9 & 9.3 & 12.5 & 13.1 & 10.2 & 11.0 & 10.3 & 9.3 & 8.5 \\
\hline Total expenditure and net lending & 22.6 & 26.4 & 25.9 & 25.8 & 27.3 & 26.4 & 25.2 & 24.4 & 23.7 \\
\hline Current expenditure & 15.1 & 14.5 & 14.9 & 14.7 & 14.8 & 15.5 & 15.6 & 15.6 & 15.5 \\
\hline Captial ependiture & 8.2 & 11.1 & 9.8 & 10.1 & 11.6 & 10.4 & 9.1 & 8.4 & 8.0 \\
\hline of which: Domestic & 3.8 & 5.1 & 4.8 & 5.1 & 6.4 & 5.4 & 5.3 & 5.2 & 5.0 \\
\hline Net lending & -0.7 & 0.8 & 1.2 & 0.9 & 0.9 & 0.5 & 0.5 & 0.3 & 0.2 \\
\hline \multicolumn{10}{|l|}{ Overall deficit (commitment basis) } \\
\hline After grants & -0.2 & -2.2 & -1.1 & -0.1 & -3.6 & -1.6 & -0.7 & -0.4 & -0.4 \\
\hline Before grants & -10.0 & -11.5 & -13.7 & -13.2 & -13.8 & -12.6 & -10.9 & -9.7 & -8.9 \\
\hline Change in arrears & -0.4 & -0.3 & -0.3 & -0.4 & -0.3 & -0.2 & -0.2 & -0.2 & -0.1 \\
\hline \multicolumn{10}{|l|}{ Overall deficit (cash) } \\
\hline After grants & -0.5 & -2.5 & -1.4 & -0.5 & -3.9 & -1.8 & -0.8 & -0.6 & -0.5 \\
\hline Before grants & -10.4 & -11.8 & -13.9 & -13.6 & -14.1 & -12.8 & -11.1 & -9.9 & -9.1 \\
\hline Financing & 0.5 & 2.5 & 1.4 & 0.5 & 3.9 & 1.8 & 0.8 & 0.6 & 0.5 \\
\hline Net external financing & 1.9 & 2.6 & 8.0 & 0.8 & 1.6 & 1.8 & 0.8 & 0.6 & 0.5 \\
\hline Net domestic financing & -1.4 & -0.1 & 0.6 & -0.4 & 2.3 & 0.0 & 0.0 & 0.0 & 0.0 \\
\hline
\end{tabular}

Sources: Rwandan authorities; and IMF staff estimates and projections.

${ }^{1}$ IMF Country Report No. 10/200.

\footnotetext{
${ }^{9}$ The temporary increase in net domestic financing still allows for a large increase ( 22 percent) in credit to private sector in the period.
} 


\section{Authorities'Views}

17. The authorities reiterated their commitment to medium-term fiscal consolidation. Their fiscal strategy over the

MEFP $\uparrow 20$

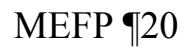
next three years is premised on unwinding the higher spending levels of recent years - 0.2 percent of GDP annual average reduction - and continued increases in domestic revenues -0.6 percent of GDP annual average increases-given the prospect of declining grants and limited scope for domestic financing. Accordingly, over the next three years, the authorities are planning on narrowing the overall deficit (excl. grants) by 2.3 percent of GDP. The projected fiscal unwinding in Rwanda is in

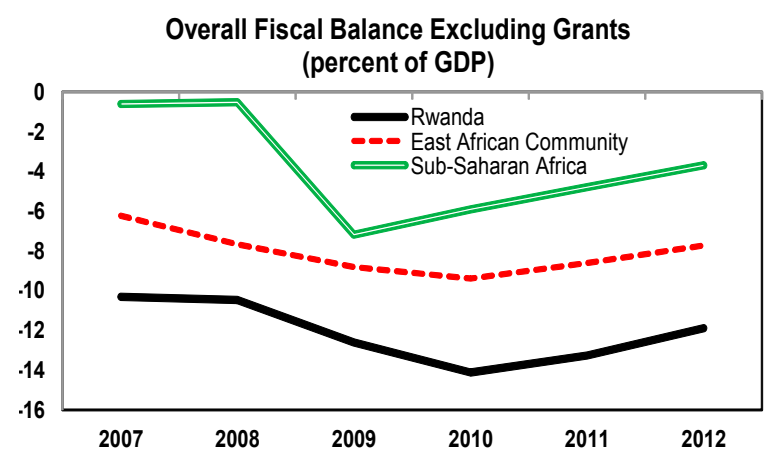
line with other countries in the region and elsewhere in Sub-Saharan Africa.

18. Consistent with the gradual fiscal consolidation, the authorities are also targeting zero net domestic financing in order to further anchor their medium-term fiscal objectives.

MEFP \21-23

They noted that they would continue to implement fiscal policy with a view toward generating fiscal space that is consistent with supporting growth and maintaining low inflation, and keeping net domestic financing (NDF) at zero so as not to crowd out the private sector. They also agreed with staff that the overall fiscal balance (incl. grants) would continue to be monitored closely as the most comprehensive indicator of fiscal policy that tracks debt dynamics.

\section{Looking ahead, they intend to strengthen their} medium-term fiscal framework (MTFF) and the effectiveness of the fiscal anchor. The MTEF will be strengthened further by

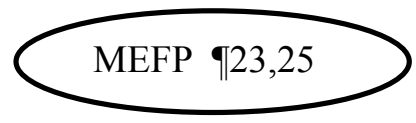
improving costing of government spending plans, informed by ongoing Public Expenditure Reviews (PERs). They noted that while the annual budget is cast within a three-year rolling macro-fiscal framework, better fiscal projections in the outer two years of the framework-in particular, projection of general budget support grants and enhancing coverage of project grants-should enhance the credibility of fiscal policy and highlight the role of net domestic financing as the fiscal anchor. They agreed that their new medium-term debt strategy-to be submitted to Cabinet by end-January 2011—-would also aid in defining a level of net domestic financing that is consistent with the development of domestic capital market with longer-dated debt instruments. To further strengthen the MTFF and anchor fiscal expectations, the authorities will publish on the website of the Ministry of Finance quarterly reports on budget execution, starting in the first half of 2011 (new structural benchmark), and intend to combine these reports in the future with a mid-year update of the macro-fiscal framework. 


\section{Domestic Revenue Mobilization}

20. A lower revenue outlook for 2010/11 has prompted the authorities to revise the $2010 / 11$ budget, to be submitted to the parliament by December 2010. Revenue shortfalls for the

MEFP $\llbracket 7,20$ fiscal year, estimated at Rwf $81 / 2$ billion ( 0.2 percent of GDP), are mainly due to lower trade taxes and corporate income taxes. The decline in trade taxes appears to be permanent, as larger-than-expected shifts in imports from the East African Community (EAC) and COMESA (Common Market for Eastern and Southern Africa), at lower duties, have reduced import duties and other applicable taxes, a phenomenon that has been observed since July 2009. On the other hand, the lower-than-expected revenues from corporate income taxes are deemed to be temporary, reflecting losses incurred by companies in 2009. So far, the authorities have responded to the revenue shortfall by identifying equivalent cuts in non priority spending, leaving intact net domestic financing at Rwf 80 billion (2.3 percent of GDP). ${ }^{10}$

\section{In the meantime, the authorities have also applied for EU-COMESA grants} which would compensate Rwanda for revenues losses from trade liberalization. The authorities correctly excluded receipts of such grants when they formulated the 2010/11 budget, but have contingency plans to fully spend these grants, if received. In light of the high level of net domestic financing and the government's policy of limiting crowding out of the private sector, staff considers early repayment of the expensive domestic debt as a better strategy than restoring the expenditures that are identified for cuts in the revised budget.

\section{To support the planned fiscal consolidation, a policy change is needed in} response to a permanent decline in revenues from trade taxes. This could include stronger revenue administration measures than originally envisaged in the PSI as well as possible tax policy measures. To this end, staff recommended frontloading some tax administration measures, including by (i) bringing forward fully automating services of the RRA District Offices, originally planned for March 2011; (ii) accelerating the audit and collection of social security taxes by the RRA; and (iii) expediting collection of tax arrears through the Standard Integrated Government Tax Administration System (SIGTAS), originally planned for December 2010.

\section{Authorities' Views}

23. The authorities reiterated their commitment to domestic revenue mobilization-a centerpiece of the PSI program. They acknowledged that the original goal to increase domestic revenue mobilization by 1.4 percent of GDP for 2010/11 is no longer achievable, given the unexpected revenue shortfalls. Nevertheless, they considered the revised 1.1 percent of GDP

\footnotetext{
${ }^{10}$ Expenditure cuts are concentrated in goods and services, transfers, as well as capital investment.
} 
revenue target as sufficiently frontloaded and ambitious compared to the original target. The authorities also noted that at present they are not considering any tax policy measures, but did not rule out future reforms in this area. To this end, they have requested a tax policy TA mission from FAD. While they agreed with the thrust of staff's proposed frontloading of tax administration measures, they preferred to maintain their time table of the planned tax administration measures, but step up their efforts for the remainder of the year to further broaden the tax base, intensify the collection of tax arrears and expedite risk-based auditing of large and medium-size tax payers.

\section{PFM reforms}

24. Rwanda has made significant progress in PFM reforms. Since 2007, progress has been achieved in the adoption of best practices in procurement policies, better monitoring and containment of payment arrears, and improved transparency of tax payer obligations and liabilities. The 2010 preliminary Public Expenditure and Financial Accountability (PEFA) assessment indicates significant increases in PFM scores in many other areas, reflecting in part progress from a low base since the 2007 PEFA assessment. However, in staff's view, weaknesses persist in several PFM areas, including: regular dissemination of key fiscal information, assessment of fiscal risks of state-owned enterprises, multi-year fiscal planning, as well as coverage and recording of project grants.

\section{Authorities' Views}

25. The authorities agreed with the PEFA assessment. They noted that the higher PEFA scores reflect their progress in PFM reforms over the past three years, including improvements in the legal framework for MEFP $q 26$ budget preparation and legislative oversight of the budget. Looking forward, the authorities are further deepening their PFM reforms, drawing on the PEFA assessment as well as their continued partnership with the donor community and the IMF's East AFRITAC.

\section{Mapping an Effective Monetary and Exchange Rate Policy}

26. The NBR pursued an accommodative monetary policy stance to support growth while inflation reached a historic low. Despite repeated cuts in the policy rate and lowering of reserve requirement on bank deposits, commercial banks' lending rates remained stubbornly high. Staff analysis of monetary transmission mechanism shows that interest rate pass-through is weak in Rwanda, especially compared to its peers (Kenya, Tanzania and Uganda) which have deeper financial markets (Box 4). Despite NBR's monetary easing, credit growth has been slow to respond as banks seem to have responded by boosting their excess reserves rather than lending. However, the recent increase in loan approval by banks, a leading indicator of future movements in credit to the private sector, is encouraging. Credit growth is expected to increase from a mere 6 percent at end-December 2009 to just over 10 percent by December 2010. Looking ahead to 2011, given the projected net credit to the 
government, reserve money is expected to grow somewhat faster than nominal GDP, accommodating growth in credit to the private sector of about 22 percent, as the recovery takes hold.

\section{Authorities'views}

27. The authorities concurred with staff on the need to maintain the current accommodative monetary policy stance, MEFP $\mid 31-32$ but they noted that they will continue monitoring inflationary pressures and take actions if needed. They attributed the low inflation in 2010 to a number of factors, including the global disinflationary trend, a relatively stable exchange rate, modest increases in monetary aggregates, as well as a good harvest that kept domestic food prices low. With the expectation of a continued economic recovery and a pickup in credit to the private sector, they did not anticipate continued low inflation in 2011 and agreed with staff that inflation is likely to edge up to 6 percent at end-2011, up from a projected 4.6 percent at end-2010.

\section{The NBR has become more proactive than in the past in conducting monetary} policy. The quarterly MPC meetings and development of high-frequency data now allow the NBR to respond more quickly to prospective shifts in aggregate demand, aggregate supply and liquidity conditions. The authorities acknowledged that further enhancement in forecasting liquidity and monetary operations are needed to better control reserve money growth. Accordingly, they look forward to the forthcoming TA in the area provided by MCM.

29. The authorities agreed that, as in the other low income countries, it would be a challenge to strengthen the monetary transmission mechanism in Rwanda. They expect lending rates to decline early next year, commensurate with the expected declines in costs of attracting deposits. They expect monetary transmission to strengthen over time with further deepening of the financial sector and increasing competition in the banking system.

\section{Exchange Rate Policy}

\section{Exchange rate flexibility should be further enhanced to reflect market} fundamentals and to support the objective of maintaining low and stable inflation. To achieve this, the NBR would need to build the capacity to determine when to intervene and re-base the exchange rate corridor, in line with changes in economic fundamentals and subordinate open market operations in the foreign exchange market to reserve money anchor.

\section{Authorities'views}

31. The NBR will continue to use an appropriate mix of monetary policy instruments, including the sale of foreign MEFP 33-35 exchange to banks, to support the objective of maintaining inflation at low levels. They noted that the exchange rate has moved more since the introduction of the corridor earlier this year than during the entire year 2009. With assistance from MCM, the NBR intends to 
further refine the exchange rate corridor which will permit greater exchange rate flexibility that reflects market fundamentals. To reinforce the operation of the corridor further, the NBR intends to remove the current average reference rate (ARR) and introduce market-based customer buying and selling rates (new structural benchmark). 


\section{Box 4. Monetary Transmission Mechanism in Rwanda}

Bank lending rates in Rwanda remain high and persistent, despite fluctuations in central bank policy rate. Deposit rates and treasury-bill rates have declined since their local peak in July 2009.

Interest rate pass-through (from policy rate to lending rate) is weak in Rwanda, but strong in Kenya, Tanzania and Uganda. A bivariate VAR model reveals that a 100 basis point (BPS) increase in the National Bank of Rwanda's (NBR) policy rate renders a 2 BPS increase in bank lending rates in the long-run. While a similar increase in Uganda's and Tanzania's policy rates pushes up lending rates by 44 BPS and 32 BPS, respectively. The long run pass through in Kenya is complete (a 100 basis point increase), exceeding the rest of the EAC.

Short-run responses are smaller, but similar across Uganda, Tanzania and Kenya, and nonexistent in Rwanda. For instance, a 100 BPS increase in the Central Bank of Kenya Rate yields a 19 BPS increase in lending rates in the short run, but a 100 basis point increase in the long run.

Changes in deposit rates strongly respond to changes in lending rates in Kenya and Tanzania, where financial markets are relatively deeper and well structured, but not in Rwanda. Deposit rates in Rwanda tend to be sticky and spread between lending and deposit rates tend to widen with changes in lending rates.

\section{Weak monetary transmission mechanism:}

To mitigate tight liquidity in 2009 , the NBR lowered its required reserves ratio from 8 to 5 percent in February 2009. Banks seem to have responded by simply boosting their excess reserves though demand for credit may have slowed down at the same time due to lower economic growth following the global recession.
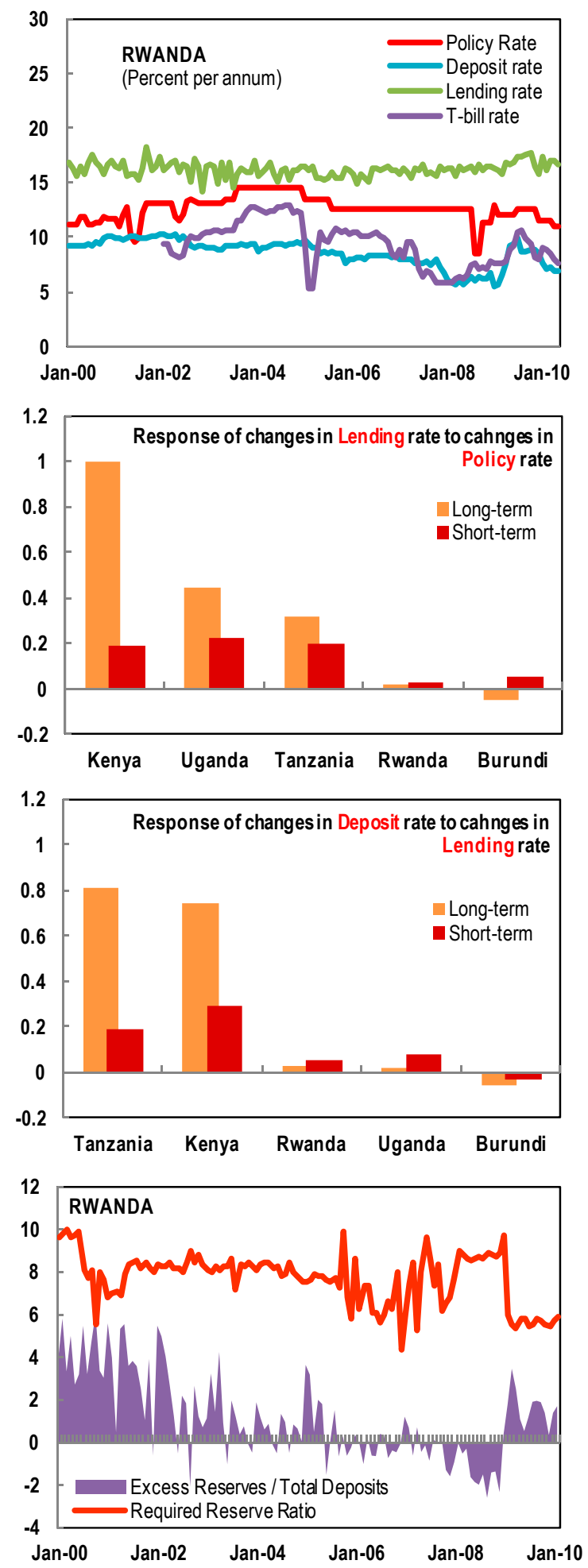


\section{Strengthening Financial Stability while Deepening Financial Markets}

\section{The banking sector generally remains sound, profitable, and well capitalized.}

However, banks have been cautious in resuming lending to the private sector, reflecting in part their attitude towards elevated risks following the tight liquidity conditions in 20082009, even though internal NBR stress test show that banks' capital would be resilient to a further deterioration in loan portfolio. High turnover of trained bank examiners continues to weaken the supervisory capacity at the NBR, and remains a potential source of vulnerability in the financial sector.

33. The authorities are taking steps to improve access to finance. Among the EAC, Rwanda has the lowest financial market depth as measured by either the ratio of private sector credit to GDP or bank deposits to GDP. Survey results also show that some 80 percent of the population, mostly in the rural areas, does not have formal access to financial products. The authorities recently granted licenses to some 400 Savings and Credit Cooperatives (SACCOs) to operate as deposit-taking institutions, with a view to grant them lending licenses as well.

Depth of the Financial Sector

(as of December 2009, unless otherwise indicated)

\begin{tabular}{|c|c|c|c|c|c|}
\hline & Burundi & Kenya & Tanzania & Uganda & Rwanda \\
\hline Fraction of People Financially Excluded ${ }^{1}$ & n.a. & 32.7 & 54 & 62 & 52 \\
\hline Bank Credit to the Private Sector (percent of GDP) & 18.5 & 32.4 & 15.0 & 13.2 & 11.9 \\
\hline Deposits (percent of GDP) & 25.0 & 41.2 & 25.6 & 18.7 & 15.2 \\
\hline M2 (percent of GDP) & 32.4 & 39.5 & 17.4 & 17.7 & 13.6 \\
\hline Number of Company Listed ${ }^{2}$ & n.a. & 55 & 15 & 11 & 1 \\
\hline
\end{tabular}

Sources: FinScope, World Bank Development Indicators, websites of stock exchanges, Rwandan authorities, and IMF staff estimates.

${ }^{1}$ People who do not use any type of financial products, either formal or informal. As for Rwanda, the fraction of people who have no access to formal financial products amounts to 78 percent. Results are based on surveys conducted in 2009 for Kenya, 2006 for Tanzania, 2006 for Uganda, and 2008 for Rwanda.

${ }^{2}$ A Kenyan media group was cross listed on the Rwanda over the counter equity market in November 2010.

\section{There is need to increase access to finance, particularly to reach the large}

unbanked segments of the population. However, the accelerated pace in expanding the reach of micro finance institutions (MFIs) and SACCOs, is a cause for concern in light of the high and growing non-performing loans in the sector, as well as capacity constraints at the NBR and other institutions to supervise these financial institutions. A rapid scaling up of these financial institutions, especially in granting licenses to lend-without first putting the necessary supervisory capacity in place-increases the risk of non-performing loans and loss of deposits, defeating the purpose of expanded financial inclusion. A forthcoming Financial Sector Assessment Program (FSAP) update (planned for early 2011) is expected to review the current licensing policy for both banks and non-bank financial institutions. 
Recommendations from the FSAP would form a basis for a possible policy reform of the licensing policy of the NBR.

\section{Authorities'views}

35. The authorities view financial deepening as important while taking steps to address limited supervision capacity. They noted that they cannot deny lending licenses to SACCOs once they meet the minimum standards, but have not fully developed plans on direct supervision or delegated monitoring of MFIs and SACCOs. The NBR is taking steps to build supervisory capacity and stem the high turnover of experienced bank examiners, including by revamping its compensation scheme and training plans. The authorities welcomed the FSAP update as it will help design an action plan to increase financial inclusion while limiting financial vulnerabilities.

\section{E. Boosting Competiveness and Growth}

36. Rwanda has made great strides in identifying and removing bottlenecks to competitiveness and growth. Staff analysis indicates that the real exchange rate is broadly in line with economic fundamentals (Box 5 and Figure 8). Rwanda has a favorable ranking in the 2010 global competitiveness indicators and continues to be assessed among the top reformers in the 2011 World Bank Doing Business rankings

(Figure 9). Nevertheless, many challenges remain to narrow Rwanda's large trade gap. The authorities have a draft export diversification strategy to broaden the export base beyond the traditional exports of tea, coffee, and minerals. To attract private investment, the strategy proposes subsidies, tax incentives and exemptions. The authorities are also implementing an ambitious investment strategy to address infrastructure bottlenecks, including in transport and energy, for which they may seek additional non-concessional financing, including public private partnerships (PPP), in the near term.

\section{Authorities'views}

37. The authorities are taking a cautious approach to granting tax exemptions and are mindful of fiscal risks associated with PPPs. They MEFP $q 24$ noted that they would weigh possible adverse effects of tax incentives on their domestic revenue mobilization efforts. They also noted that although the PPP unit is housed at the Rwanda Development Board (RDB), the one-stop shop for investors, the Ministry of Finance will fully assess fiscal risks associated with any PPPs before taking any decisions. 


\section{Box 5. Exchange Rate Assessment and External Competitiveness}

Staff estimates using three complementary approaches suggest that the Rwandan franc is broadly in line with economic fundamentals but with modest overvaluation in recent years. The estimates are based on the macroeconomic balance (MB) approach, the external sustainability approach (ES), and the equilibrium real exchange rate (ERER) approach.

\begin{tabular}{|c|c|c|c|}
\hline \multicolumn{4}{|c|}{$\begin{array}{l}\text { Exchange Rate Valuation Assessment } \\
\text { (in percent) }\end{array}$} \\
\hline & \multicolumn{2}{|c|}{ Current Account/GDP } & \multirow{2}{*}{$\frac{\text { REER }^{2}}{\text { Degree of over(under) valuation }}$} \\
\hline & Norm & Underlying CA & \\
\hline Macroeconomic balance & -3.36 & -4.83 & -3.22 \\
\hline External Sustainability ${ }^{3}$ & -4.59 & -4.83 & -0.52 \\
\hline Equilibrium real exchange rate & $\ldots$ & $\ldots$ & -11.4 \\
\hline \multicolumn{4}{|c|}{$\begin{array}{l}\text { 1. Source: IMF staff estimates. See appendix for details. } \\
\text { 2. (-) means overvaluation } \\
\text { 3. NFA stabilizing at } 45.2 \text { percent of GDP. }\end{array}$} \\
\hline
\end{tabular}

Macroeconomic balance: The current account deficit "norm" is estimated at 3.4 percent of GDP, with the underlying current account deficit (after eliminating temporary influences) estimated at 4.8 percent of GDP, in line with the medium term projection. With an estimated current account elasticity

of -0.46 , a real effective exchange rate depreciation of 3.2 percent would be required to close the gap between the "norm" and the underlying current account deficit.

External Sustainability: With a projected negative net international investment position of about 45 percent of GDP, the net foreign liability stabilizing current account deficit was estimated at 4.6 percent of GDP, and given a current account elasticity of -0.46 , a real effective exchange rate depreciation of about 0.5 percent would be required to close the gap.

Equilibrium real exchange rate: Approaches that model the real exchange rate directly suggest that in general the real exchange rate has broadly been close to its equilibrium level. However, for 2009; the model suggests a potential currency overvaluation of about 11.4 percent. The real exchange rate overvaluation for 2010 is likely to be lower than the 11.4 percent in 2009 , given that the actual real exchange rate has depreciated by 6 percent through September 2010, and the likely shift in equilibrium based on developments in the macroeconomic fundamentals.

Rwanda has made important strides to improve competitiveness. The World Bank's Doing Business 2011 report ranks Rwanda $58^{\text {th }}$ out of 183 and notes that the country remains among the top global reformers. ${ }^{1}$ The Global Competitiveness Report 2010-2011 ranks Rwanda fifth in sub-Saharan Africa (SSA), and $80^{\text {th }}$ out of 139 countries overall. ${ }^{2}$ Notable improvements in recent years include improving the ease of starting and closing a business, registering property, trading across borders, and investor protection. While Rwanda compares favorably to its peers in the East-African Community (EAC) and SSA, areas where additional progress is needed include infrastructure, financial development, health and poverty, education, and innovation. A survey in the Global Competitiveness Report about perceptions of doing business listed access to finance, taxation, infrastructure, and education as the most problematic for Rwanda. While some of these are also constraints on business activity in other EAC countries, access to finance is considered a bigger problem in Rwanda while corruption and the efficiency of the government are considered more problematic in other EAC countries.

\footnotetext{
${ }^{1}$ www.doingbusiness.org.

${ }^{2}$ Published by World Economic Forum (www.weforum.org).
} 
Figure 8. Rwanda: Exchange Rate Assessment.

A stronger dollar in the last year...
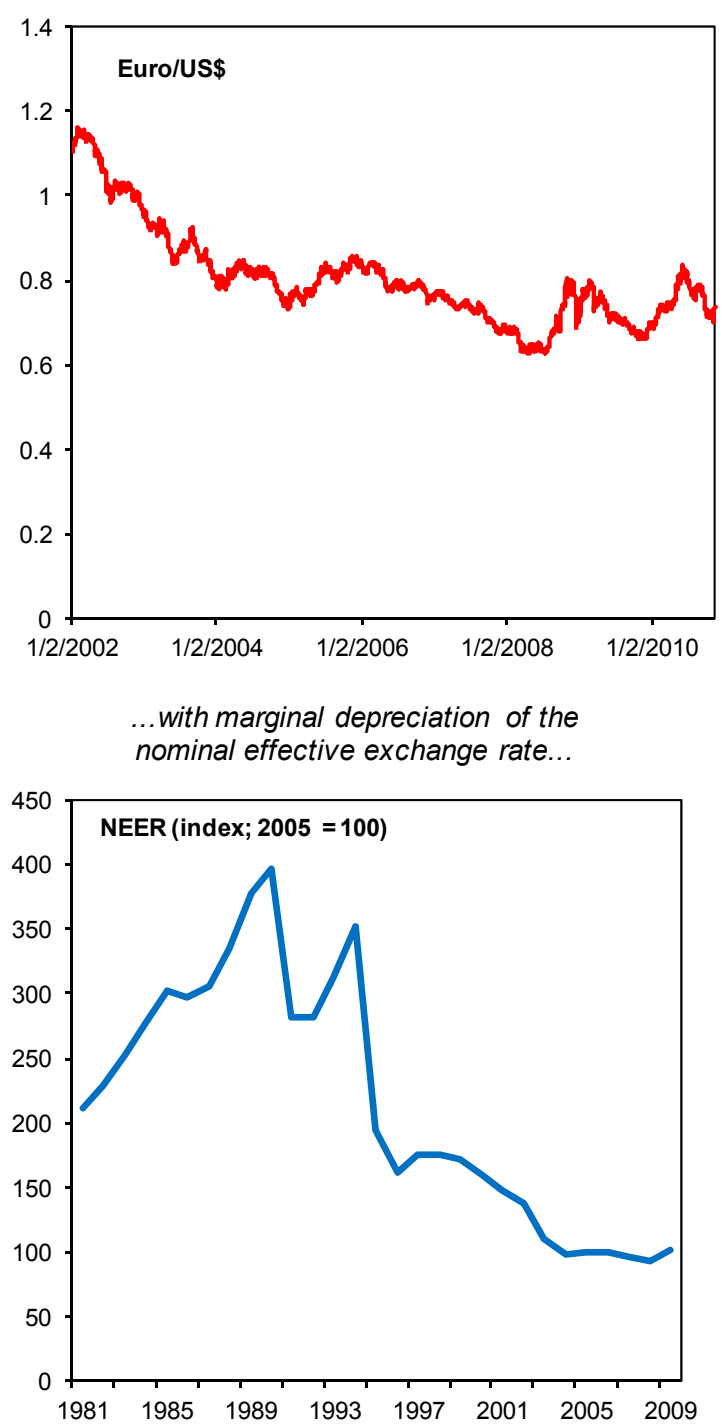

...has reflected in some depreciation of the Rwandan franc...
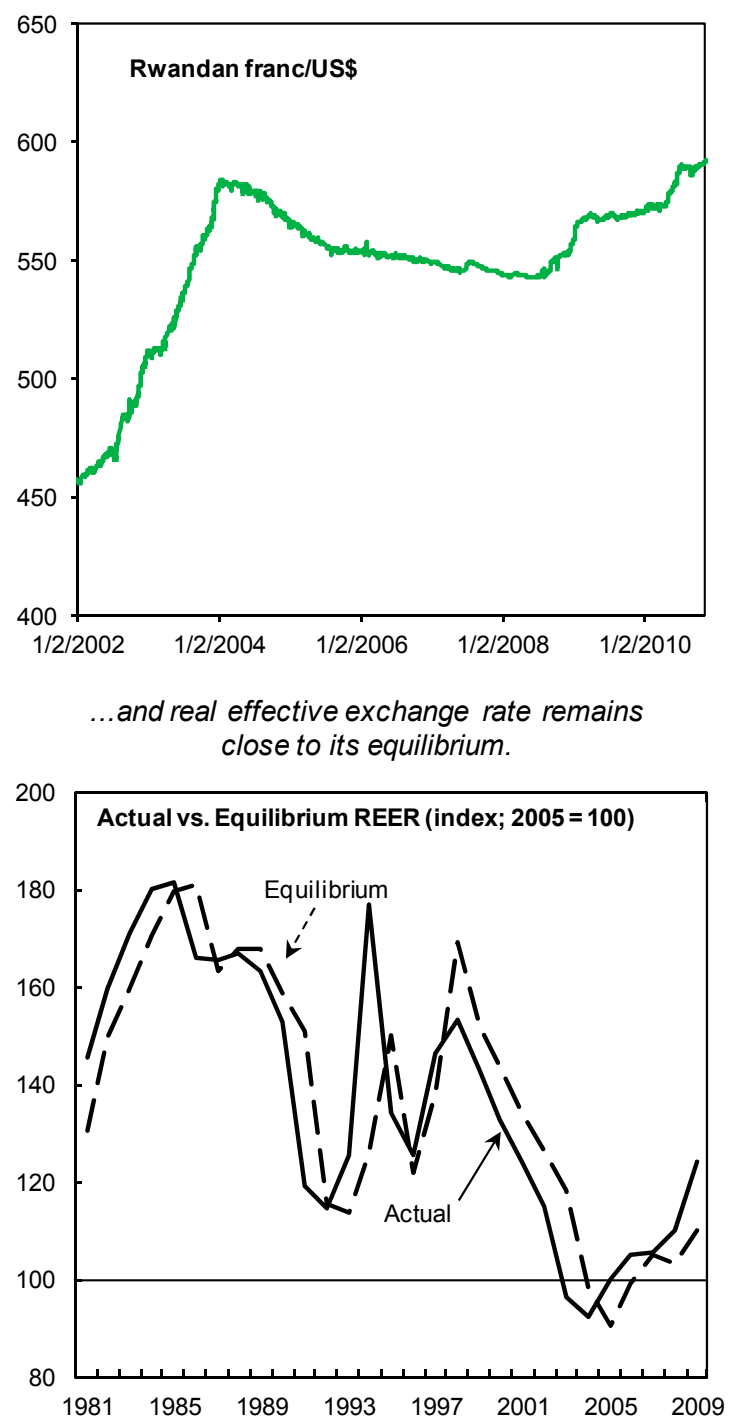

Sources: IMF, Information Notice System and Thomson Reuters. 
Figure 9. Rwanda: Indicators of Competitiveness.

Rwanda compares favorably to its peers in competitiveness...

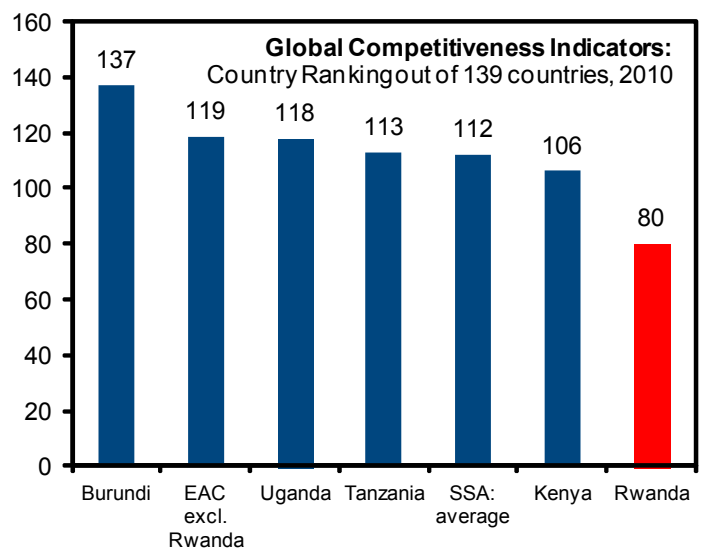

... including through improving the legal environment.

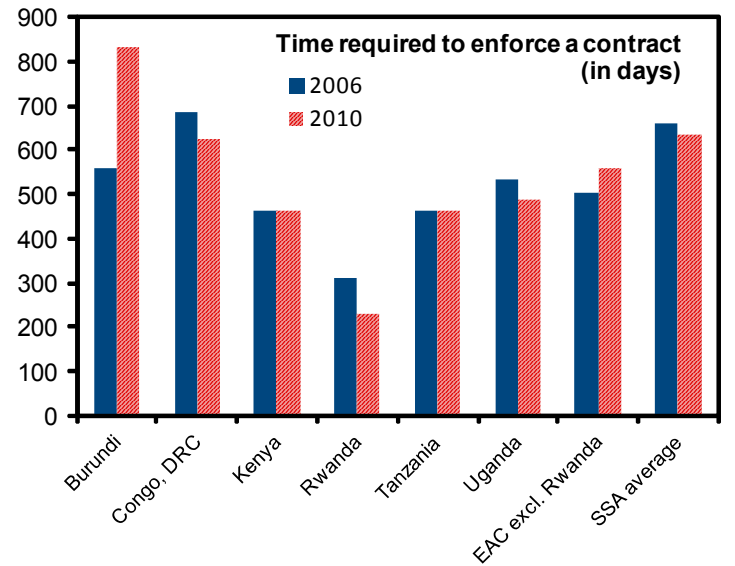

...including high costs to trade.

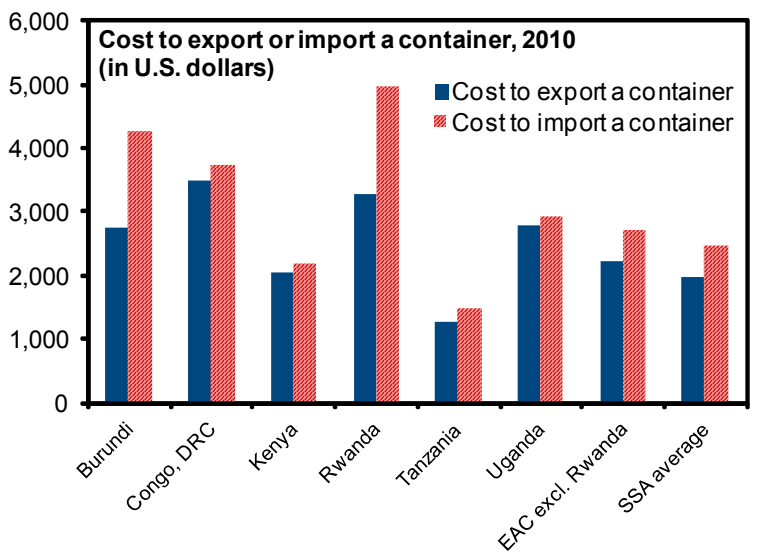

... reflecting recent measures to lower the cost of doing business...

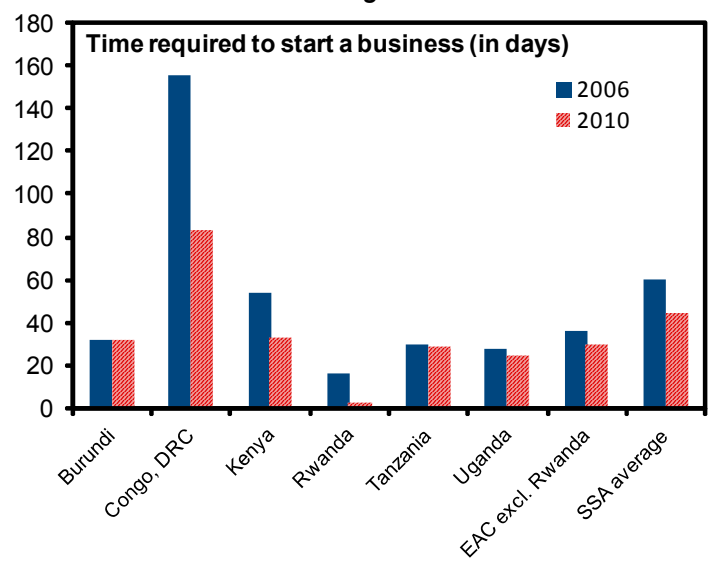

Nonetheless, there remain several areas where additional progress would be needed ...

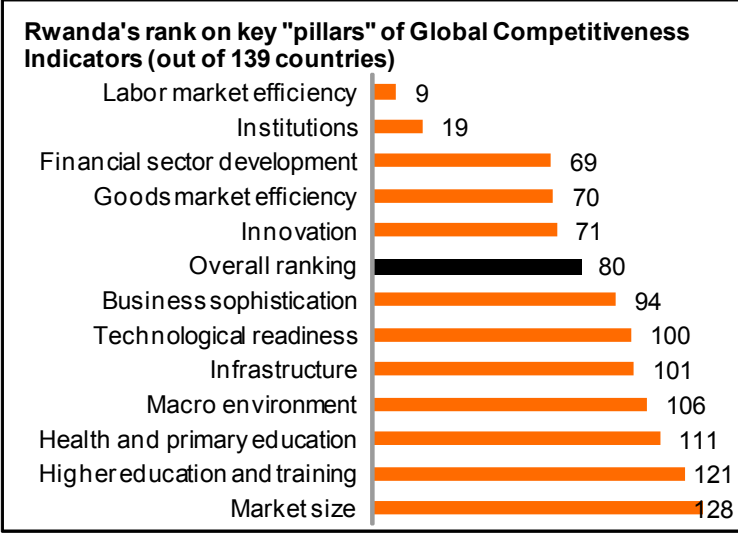

Access to finance also remains a problem, especially compared to Rwanda's peers.

\begin{tabular}{|c|c|c|c|c|c|c|}
\hline \multicolumn{7}{|c|}{ The Most Problem atic Factors for Doing Business: EAC Comparis on } \\
\hline & Burundi & Kenya & Rw anda & Tanzania & Uganda & $\begin{array}{c}\text { Average } \\
\text { EAC } \\
\text { (excl. } \\
\text { Rw anda) }\end{array}$ \\
\hline Access to financing & 20.0 & 12.9 & 24.9 & 15.1 & 15.3 & 15.8 \\
\hline Tax regulations & 10.5 & 5.0 & 15.1 & 7.9 & 4.4 & 7.0 \\
\hline Tax rates & 7.4 & 7.2 & 13.9 & 9.0 & 8.9 & 8.1 \\
\hline Inadequate supply of infrastructure & 7.2 & 9.5 & 10.9 & 13.3 & 13.0 & 10.8 \\
\hline Inadequately educated w orkforce & 3.5 & 1.1 & 9.6 & 3.9 & 5.0 & 3.4 \\
\hline Corruption & 19.5 & 21.7 & 0.6 & 17.4 & 21.9 & 20.1 \\
\hline
\end{tabular}

Sources: IMF staff estimates; World Bank: Doing Business and World Development Indicators; and Global Economic Forum: The Global Competitiveness Report 2010-11. 


\section{Statistical Issues}

38. Substantial progress has been made in compilation and dissemination of economic statistics, but weaknesses remain in the area of national accounts and balance of payment statistics. In the area of national accounts, notable improvements include the disseminating quarterly GDP estimates, updating the household expenditure survey, and revising the methodology for conducting ex-ante and ex-post agricultural crop assessments. The ex-post agricultural survey is planned to be used for the upcoming 2011 season A crop (new structural benchmark). As an interim measure to improve agricultural statistics, informal ex-post agricultural visits were conducted in 2009 and the first half of 2010 to corroborate the pre-harvest survey. For 2010, this resulted in a significant downward revision in the growth rate of agricultural output. The 2010/11 budget has also allocated more resources to the national statistics office. In other areas, surveys of cross-border trade have strengthened balance of payments statistics but lack of quarterly BOP statistics hampers analysis of external trade performance and compilation of national accounts statistics. Despite recent improvements, weaknesses remain in the methodology of national accounts, including lack of a comprehensive economy-wide enterprise survey, the need to establish robust relationship between ex-ante and ex-post agricultural crop yields and uncertainty surrounding the size of the informal sector.

\section{Program Issues}

39. The program risks may have elevated somewhat, notwithstanding the authorities' commitment to their program. The main risk includes further deterioration in the revenue outlook beyond the level that is already incorporated in the revised FY 2010/11 budget.

40. The appended Letter of Intent and accompanying Memorandum of Economic and Financial Policies (MEFP) outlines the authorities' policy objectives for the remainder of 2010/11. Quantitative assessment criteria and indicative targets and structural benchmarks for end-June 2011 are shown in Tables 1 and 2 of the MEFP. The updated MEFP includes three additional structural benchmarks in fiscal, exchange rate policy and statistics for the period ending in June 2011.

41. The updated TMU includes some changes and modifications to the assessment criteria for end-December 2010 relative to the last staff report (IMF Country Report No. 10/200) and establishes assessment criteria for end-June 2011. The updated changes are as follows:

- $\quad$ The adjustors for net foreign assets and net domestic financing have been revised to keep pace with the size of delays in donor grants which have grown over time in Rwanda. This adjustment would allow the authorities greater flexibility in smoothing 
government spending, addressing temporary cash flow problems and maintaining prudent reserves.

- $\quad$ Reserve money targets have been better aligned with seasonalities in currency in circulation. This would help the authorities manage repo operations in advance, thereby aiding in a better control over reserve money, which is the anchor for monetary policy.

- $\quad$ For program purposes, the domestic debt-an indicative target under the PSI-excludes debt issued by the NBR for monetary policy purposes. This change removes interference of the cap on domestic debt limit with the central bank's ability to effectively mop up excess liquidity to achieve its inflation objective. The proceeds from the sale of central bank debt would stay in a blocked account at the NBR and not available for budgetary financing.

- In line with the Fund's new debt limit policy, one state-owned commercial bank is now excluded from the debt limit under the PSI, on the grounds that the bank poses little fiscal risk since it has no history of receiving government transfers. This change would allow the bank to borrow on non-concessional terms without seeking or being granted a government guarantee. The authorities also requested a second bank be excluded, the national development bank. The mission considered that this bank did not qualify for exclusion on the grounds that it poses fiscal risks, including because it lacks an independent management board and regularly receives budgetary transfers and tax exemptions. The authorities did not share the staff's assessment and noted that the Fund's policy on exclusions was not sufficiently flexible to allow for countryspecific circumstances, including that the Rwanda government has no history of interfering in the operations of state-owned banks.

\section{Staff APPRAisal}

42. The economic outlook is favorable, but downside risks remain. Over the short to medium-term, growth is driven by: (i) the government's investment strategy, supported by a more business-friendly environment; (ii) recovery in external demand; and (iii) pick-up in credit to the private sector. Risks to the outlook remain on the downside, reflecting slowerthan-expected pick-up in external demand and in domestic credit.

\section{Rwanda has achieved high growth and macroeconomic stability over the last} decade. Rwanda's resiliency to external shocks has improved further, thanks to prudent policies, substantial debt relief, and heavy reliance on concessional borrowing.

\section{Sustained labor-intensive growth is needed to reduce poverty, which remains}

high. Removing infrastructure bottlenecks is a step in the right direction. Increase in 
agricultural productivity could generate sustainable employment for a large segment of the population who live in rural areas.

45. The recent implementation of countercyclical fiscal and monetary policies to mitigate the impact of the global economic downturn is a welcome departure from the procyclical policies of the past. The authorities should build on this momentum to enhance their capacity to implement countercyclical policies in the future.

46. The authorities' medium-term path toward fiscal consolidation is welcomed. After a large stimulus in 2009/10, a further though much smaller stimulus in 2010/11 seems to be appropriate as it further supports the nascent recovery. Looking ahead, fiscal consolidation is anchored on: (i) gradually reducing spending, while protecting priority spending in line with poverty reduction strategy; (ii) boosting domestic revenues through tax administration while addressing shortfalls in trade taxes. Tax policy reforms should also be considered in the future in order to support the authorities' domestic revenue mobilization efforts.

47. The medium term fiscal framework needs to be strengthened further. Important steps include: better costing of government spending plans in the MTEF, better alignment of projected external grants with a level of NDF that is informed by a MTDS, as well as continued commitment to quarterly dissemination of fiscal data and fiscal strategy which would anchor fiscal expectations.

48. Reforms of PFM and debt management capacity and expenditure rationalization need to be implemented vigorously. These include implementing well designed public investment projects and their monitoring, improving the coverage of project grants, and enhancing the overall capacity to assess the costs and benefits of scaled-up nonconcessional financing, including fiscal risks associated with the PPPs.

49. The monetary transmission mechanism needs to be strengthened. This includes strengthening monetary operations of the NBR, enhancing exchange rate flexibility, creating an active interbank market and deepening the financial markets. Although some of these reforms are expected to gradually strengthen the interest rate pass-through, the NBR should continue to use its reserve money as the anchor in conducting monetary policy while using changes in its policy rate to strengthen its signaling role and interest rate pass through. Development of an active debt market with longer-dated debt instruments would be a welcome step as it creates a yield curve for the monetary authorities to shape inflation expectations. However, progress in this direction requires a demonstrated need for ongoing government financing requirement - anchored in the government's MTDS as well as asset and liability management-and a secondary market that provides a benchmark for government debt instruments of varying maturities.

50. The NBR's MPC decision process and review of financial stability should be further enhanced by a sustained scaling up of analytical support. The authorities should 
build up the necessary expertise to provide analytical support for the MPC and monitor the implementation of the new exchange rate framework. The authorities should continue reforms (with assistance from MCM) toward greater exchange rate flexibility to enhance monetary policy effectiveness and ensure that exchange rate responds to movements in economic fundamentals. Further analytical work on financial stability aspects of the NBR's semi-annual policy statement could also benefit from the FSAP Update mission planned for early 2011.

51. The NBR should develop an action plan that trains and retains staff for the banking supervision department. A transitional plan is needed to mitigate financial sector vulnerability while waiting for the FSAP Update to take up the issue in early 2011.

52. Deepening access to finance matters for growth and poverty reduction. However, the decision to grant license to lend to over 400 SACCOs and MFIs should take into account the limited supervision capacity at the NBR and other institutions. Recommendations on requirements for NBR's lending licenses for SACCO's and MFIs should await the outcome of the upcoming FSAP Update.

53. The real exchange rate is broadly in line with the fundamentals, although Rwanda is still an expensive place to do business. Improvements in business climate, infrastructure, and skills mix and education of the labor force are key to lowering the cost of doing business. Public investment in these areas would therefore be preferable to granting tax exemptions to investors, since the latter could jeopardize fiscal sustainability.

54. Further improvements in national accounts and balance of payments statistics are needed. Specifically, efforts are needed to develop a comprehensive economy-wide enterprise survey to reduce uncertainty surrounding the size of the informal sector.

55. Staff recommends completion of the first PSI review and modification of the assessment criteria for end-December 2010 under the PSI based on Rwanda's performance and the strength of the program.

56. It is recommended that the next Article IV consultation take place within 24 months, subject to the provisions of the decision on consultation cycles in program countries. 
Table 1. Rwanda: Millennium Development Goals

\begin{tabular}{|c|c|c|c|c|c|}
\hline & 1990 & 1995 & 2000 & 2005 & 2008 \\
\hline \multicolumn{6}{|l|}{ Goal 1: Eradicate extreme poverty and hunger } \\
\hline Employment to population ratio, $15+$, total (\%) & 87 & 87 & 84 & 80 & 80 \\
\hline Employment to population ratio, ages $15-24$, total (\%) & 79 & 80 & 73 & 66 & 64 \\
\hline GDP per person employed (constant 1990 PPP \$) & .. & .. & .. & .. & .. \\
\hline Income share held by lowest $20 \%$ & .. & .. & 5 & .. & .. \\
\hline Malnutrition prevalence, weight for age ( $\%$ of children under 5 ) & 24 &.. & 20 & 18 & .. \\
\hline Poverty gap at $\$ 1.25$ a day (PPP) (\%) &.. & .. & 38 & .. & .. \\
\hline Poverty headcount ratio at $\$ 1.25$ a day (PPP) ( $\%$ of population) &.. &.. & 77 & .. & .. \\
\hline Vulnerable employment, total (\% of total employment) &.. & 93 & .. & .. & .. \\
\hline \multicolumn{6}{|l|}{ Goal 2: Achieve universal primary education } \\
\hline Literacy rate, youth female ( $\%$ of females ages $15-24$ ) & 75 & .. & 77 & .. & 77 \\
\hline Literacy rate, youth male (\% of males ages $15-24)$ & 75 &.. & 79 & .. & 77 \\
\hline Persistence to last grade of primary, total (\% of cohort) &.. & .. & 27 & 31 & .. \\
\hline Primary completion rate, total ( $\%$ of relevant age group) & 37 & .. & 22 & 40 & 54 \\
\hline Total enrollment, primary (\% net) &.. &.. & 76 & 84 & 96 \\
\hline \multicolumn{6}{|l|}{ Goal 3: Promote gender equality and empower women } \\
\hline Proportion of seats held by women in national parliaments (\%) & 17 & 17 & 17 & 49 & 56 \\
\hline Ratio of female to male primary enrollment $(\%)$ & 92 & .. & 97 & 104 & 101 \\
\hline Ratio of female to male secondary enrollment (\%) & 74 &.. & 94 & 90 & 90 \\
\hline Ratio of female to male tertiary enrollment (\%) &.. &.. & 48 & 62 & .. \\
\hline Share of women employed in the nonagricultural sector (\% of total nonagricultural employment) &.. & 32.4 & 33.0 &.. & .. \\
\hline \multicolumn{6}{|l|}{ Goal 4: Reduce child mortality } \\
\hline Immunization, measles ( $\%$ of children ages $12-23$ months) & 83 & 84 & 74 & 89 & 92 \\
\hline Mortality rate, infant (per 1,000 live births) & 106 & 132 & 112 & 85 & 72 \\
\hline Mortality rate, under-5 (per 1,000$)$ & 174 & 225 & 186 & 136 & 112 \\
\hline \multicolumn{6}{|l|}{ Goal 5: Improve maternal health } \\
\hline Adolescent fertility rate (births per 1,000 women ages $15-19$ ) &.. & .. & 50 & 40 & 36 \\
\hline Births attended by skilled health staff ( $\%$ of total) & 26 & .. & 31 & 39 & 52 \\
\hline Contraceptive prevalence ( $\%$ of women ages $15-49$ ) & 21 & 14 & 13 & 17 & 36 \\
\hline Maternal mortality ratio (modeled estimate, per 100,000 live births) &.. & .. & .. & 1,300 & .. \\
\hline Pregnant women receiving prenatal care (\%) & 94 & .. & 92 & 94 & 96 \\
\hline Unmet need for contraception ( $\%$ of married women ages $15-49$ ) & 39 &.. & 36 & 38 & .. \\
\hline \multicolumn{6}{|l|}{ Goal 6: Combat HIVIAIDS, malaria, and other diseases } \\
\hline Children with fever receiving antimalarial drugs ( $\%$ of children under age 5 with fever) & .. & .. & 13 & 12 & .. \\
\hline Condom use, population ages $15-24$, female (\% of females ages $15-24)$ &.. &.. & 3 & 5 & .. \\
\hline Condom use, population ages $15-24$, male ( $\%$ of males ages $15-24)$ &.. &.. & 24 & 19 & .. \\
\hline Incidence of tuberculosis (per 100,000 people) & 167 & $24 \ddot{1}$ & 348 & 418 & 387 \\
\hline Prevalence of HIV, female (\% ages $15-24)$ &.. & .. & .. & 1.4 & 1.4 \\
\hline Prevalence of HIV, male (\% ages 15-24) &.. &.. & .. & 0.5 & 0.5 \\
\hline Prevalence of HIV, total (\% of population ages $15-49$ ) & $9 . \ddot{2}$ & 7.0 & 4.7 & 3.1 & 2.8 \\
\hline Tuberculosis case detection rate (all forms) &.. & 33 & 31 & 26 & 26 \\
\hline \multicolumn{6}{|l|}{ Goal 7: Ensure environmental sustainability } \\
\hline CO2 emissions (kg per PPP \$ of GDP) & 0 & 0 & 0 & 0 & 0 \\
\hline CO2 emissions (metric tons per capita) & 0 & 0 & 0 & 0 & 0 \\
\hline Forest area ( $\%$ of land area) & 12.9 & 13.4 & 13.9 & 19.5 & 21.7 \\
\hline Improved sanitation facilities (\% of population with access) & 29 & 26 & 25 & 23 & 23 \\
\hline Improved water source (\% of population with access) & 65 & 64 & 65 & 65 & 65 \\
\hline Marine protected areas (\% of total surface area) &.. &.. & .. & .. & 0 \\
\hline Terrestrial protected areas ( $\%$ of total surface area) &.. &.. & .. & .. & 8 \\
\hline \multicolumn{6}{|l|}{ Goal 8: Develop a global partnership for development } \\
\hline Net ODA received per capita (current US\$) & 40 & 128 & 40 & 64 & 96 \\
\hline Debt service (PPG and IMF only, \% of exports, excluding workers' remittances) & 10 & 20 & 25 & 4 & 1 \\
\hline Internet users (per 100 people) & 0.0 & 0.0 & 0.1 & 0.6 & 3.1 \\
\hline Mobile cellular subscriptions (per 100 people) & 0 & 0 & 0 & 2 & 14 \\
\hline Telephone lines (per 100 people) & 0 & 0 & 0 & 0 & 0 \\
\hline \multicolumn{6}{|l|}{ Other } \\
\hline Fertility rate, total (births per woman) & 7 & 6 & 6 & 6 & 5 \\
\hline GNI per capita, Atlas method (current US\$) & 340 & 230 & 250 & 250 & 440 \\
\hline GNI, Atlas method (current US\$) (billions) & 2.4 & 1.3 & 2.0 & 2.3 & 4.3 \\
\hline Gross capital formation ( $\%$ of GDP) & 14.6 & 13.4 & 18.3 & 21.6 & 24.1 \\
\hline Life expectancy at birth, total (years) & 33 & 29 & 43 & 48 & 50 \\
\hline Literacy rate, adult total (\% of people ages 15 and above) & 58 & .. & 65 & .. & 70 \\
\hline Population, total (billions) & 0.0 & 0.0 & 0.0 & 0.0 & 0.0 \\
\hline Trade (\% of GDP) & 19.7 & 31.0 & 34.4 & 36.9 & 46.1 \\
\hline
\end{tabular}

Source: World Development Indicators

Figures in italics refer to periods other than those specified. 
Table 2. Rwanda: Selected Economic and Financial Indicators, 2006-15

\begin{tabular}{|c|c|c|c|c|c|c|c|c|c|c|c|}
\hline & \multirow[t]{2}{*}{2006} & \multirow[t]{2}{*}{2007} & \multirow[t]{2}{*}{2008} & \multirow{2}{*}{$\begin{array}{c}2009 \\
\text { Est. }\end{array}$} & \multicolumn{2}{|c|}{2010} & 2011 & 2012 & 2013 & 2014 & 2015 \\
\hline & & & & & Prog & Proj & \multicolumn{5}{|c|}{ Projection } \\
\hline & \multicolumn{11}{|c|}{ (Annual percentage changes, unless otherwise indicated) } \\
\hline \multicolumn{12}{|l|}{ Output and prices } \\
\hline Real GDP growth & 9.2 & 5.5 & 11.2 & 4.1 & 5.4 & 6.5 & 6.5 & 7.0 & 6.8 & 6.5 & 6.5 \\
\hline Real GDP (per capita) & 7.3 & 3.3 & 8.9 & 2.0 & 3.2 & 4.3 & 4.3 & 4.8 & 4.6 & 4.3 & 4.3 \\
\hline GDP deflator & 9.8 & 13.2 & 12.6 & 11.0 & 6.7 & 3.8 & 5.2 & 5.1 & 5.1 & 5.2 & 5.2 \\
\hline Consumer prices (period average) & 8.8 & 9.1 & 15.4 & 10.3 & 6.4 & 3.2 & 5.3 & 5.5 & 5.0 & 5.0 & 5.0 \\
\hline Consumer prices (end of period) & 12.1 & 6.6 & 22.3 & 5.7 & 7.0 & 4.6 & 6.0 & 5.0 & 5.0 & 5.0 & 5.0 \\
\hline \multicolumn{12}{|l|}{ External sector } \\
\hline Export of goods, f.o.b (in U.S. dollars) & 17.9 & 19.9 & 51.4 & -28.0 & 24.6 & 48.1 & -0.4 & 10.4 & 10.1 & 13.7 & 13.8 \\
\hline Imports of goods, f.o.b (in U.S. dollars) & 26.2 & 30.2 & 51.5 & 16.4 & 19.1 & 11.9 & 19.6 & -7.9 & -1.0 & 6.8 & 8.1 \\
\hline Export volume & 12.5 & -0.2 & 21.8 & -20.0 & 11.0 & 16.5 & 8.0 & 13.7 & 10.9 & 14.4 & 11.2 \\
\hline Import volume & 27.0 & 31.0 & 20.2 & 9.4 & 9.1 & 8.8 & 16.6 & -8.1 & -1.9 & 5.5 & 5.4 \\
\hline Terms of trade (deterioration $=-$ ) & 5.5 & 20.9 & -1.4 & -15.4 & 2.9 & 23.6 & -10.1 & -3.1 & -1.7 & -1.9 & -0.2 \\
\hline \multicolumn{12}{|l|}{ Money and credit ${ }^{1}$} \\
\hline Net domestic assets ${ }^{2}$ & 2.6 & 7.6 & 10.3 & 4.9 & 10.9 & 11.8 & 10.5 & 14.8 & 13.1 & 11.8 & 10.2 \\
\hline Domestic credit ${ }^{2}$ & 8.2 & 12.0 & 20.5 & 3.8 & 11.0 & 16.2 & 9.1 & 12.2 & 12.6 & 10.5 & 10.2 \\
\hline Government $^{2}$ & -5.6 & 0.2 & -18.1 & 0.2 & -2.5 & 8.6 & -5.8 & 0.0 & 0.0 & 0.0 & 0.0 \\
\hline Economy $^{2}$ & 13.8 & 11.9 & 38.6 & 3.6 & 13.5 & 7.6 & 14.9 & 12.2 & 12.6 & 10.5 & 10.2 \\
\hline Broad money (M2) & 31.3 & 30.8 & 24.2 & 13.1 & 12.4 & 12.9 & 13.8 & 14.0 & 13.3 & 13.0 & 13.0 \\
\hline Reserve money ${ }^{3}$ & 11.9 & 30.7 & 23.5 & 0.3 & 12.5 & 11.7 & 13.9 & 14.0 & 13.3 & 13.0 & 13.0 \\
\hline \multirow[t]{2}{*}{ Velocity (GDP/M2; end of period) } & 6.0 & 5.5 & 6.5 & 5.6 & 5.6 & 5.5 & 5.4 & 5.3 & 5.2 & 5.2 & 5.2 \\
\hline & \multicolumn{11}{|c|}{ (Percent of GDP) } \\
\hline \multicolumn{12}{|l|}{ National income accounts } \\
\hline National savings & 7.4 & 8.3 & 9.1 & 3.8 & 3.5 & 6.1 & 4.0 & 6.3 & 8.2 & 9.2 & 10.0 \\
\hline Gross investment & 19.7 & 20.2 & 23.5 & 22.4 & 22.8 & 23.4 & 24.1 & 22.3 & 21.4 & 21.0 & 20.6 \\
\hline Of which: private (including public enterprises) & 12.8 & 12.4 & 13.1 & 12.4 & 11.7 & 12.6 & 13.0 & 12.7 & 12.7 & 12.8 & 12.8 \\
\hline \multicolumn{12}{|l|}{ Government finance $^{4}$} \\
\hline Total revenue (excl. grants) & 12.2 & 12.4 & 12.6 & 14.9 & 12.2 & 12.5 & 13.6 & 13.7 & 14.3 & 14.6 & 14.8 \\
\hline Total expenditure and net lending & 23.7 & 22.0 & 22.6 & 26.4 & 25.9 & 25.8 & 27.3 & 26.4 & 25.2 & 24.4 & 23.7 \\
\hline Capital expenditure & 7.6 & 7.0 & 8.2 & 11.1 & 9.8 & 10.1 & 11.6 & 10.4 & 9.1 & 8.4 & 8.0 \\
\hline Current expenditure & 15.9 & 14.2 & 15.1 & 14.5 & 14.9 & 14.7 & 14.8 & 15.5 & 15.6 & 15.6 & 15.5 \\
\hline Primary fiscal balance ${ }^{5}$ & -2.6 & -1.6 & -3.3 & -2.2 & -5.3 & -5.2 & -5.3 & -5.0 & -4.7 & -4.4 & -4.0 \\
\hline Domestic fiscal balance ${ }^{6}$ & -5.9 & -4.6 & -5.6 & -5.3 & -8.5 & -8.0 & -8.5 & -7.5 & -7.0 & -6.3 & -5.8 \\
\hline \multicolumn{12}{|l|}{ Overall fiscal balance (payment order) ${ }^{4}$} \\
\hline After grants & 5.2 & -1.4 & -0.2 & -2.2 & -1.1 & -0.1 & -3.6 & -1.6 & -0.7 & -0.4 & -0.4 \\
\hline Before grants & -11.5 & -9.6 & -10.0 & -11.5 & -13.7 & -13.2 & -13.8 & -12.6 & -10.9 & -9.7 & -8.9 \\
\hline External sector & & & & & & & & & & & \\
\hline External current account balance & & & & & & & & & & & \\
\hline Including official transfers & -4.3 & -2.2 & -4.9 & -8.5 & -7.9 & -6.7 & -9.0 & -6.4 & -4.6 & -3.9 & -3.4 \\
\hline Excluding official transfers & -12.3 & -11.9 & -14.4 & -18.6 & -19.3 & -17.3 & -20.2 & -15.9 & -13.2 & -11.8 & -10.6 \\
\hline External debt (end of period) & 15.6 & 15.3 & 14.4 & 14.5 & 16.4 & 14.9 & 17.7 & 18.2 & 17.3 & 16.1 & 14.8 \\
\hline $\begin{array}{l}\text { Net present value of external debt } \\
\text { (percent of exports of goods and services) }\end{array}$ & 53.1 & 57.7 & 49.9 & 89.2 & 102.8 & 92.5 & 125.7 & 130.1 & 116.8 & 101.0 & 86.6 \\
\hline Scheduled debt service ratio & & & & & & & & & & & \\
\hline (percent of exports of goods and services) & 3.7 & 2.4 & 1.3 & 1.8 & 3.0 & 3.6 & 6.2 & 6.4 & 8.3 & 9.0 & 8.0 \\
\hline Gross reserves (in months of imports of goods and services) ${ }^{7}$ & 5.6 & 4.7 & 4.6 & 5.5 & 4.8 & 4.6 & 5.2 & 5.1 & 4.8 & 4.7 & 4.7 \\
\hline & & & & & illions o & f U.S. d & ollars) & & & & \\
\hline Gross official reserves & 439.6 & 552.4 & 596.4 & 742.2 & 744.3 & 737.2 & 767.3 & 755.7 & 756.4 & 797.6 & 843.6 \\
\hline Memorandum item: & & & & & & & & & & & \\
\hline Nominal GDP (billions of Rwanda francs) & 1,716 & 2,049 & 2,565 & 2,964 & 3,333 & 3,278 & 3,672 & 4,131 & 4,639 & 5,195 & 5,819 \\
\hline Sources: Rw andan authorities and IMF staff estimates and projections. & & & & & & & & & & & \\
\hline${ }^{1}$ Projections are based on the program exchange rate of Rw $\mathrm{F}$ per US dolla & f 571 & & & & & & & & & & \\
\hline${ }^{2}$ As a percent of the beginning-of-period stock of broad money. & & & & & & & & & & & \\
\hline${ }^{3}$ Increase in 2007 reflects rebasing of the monetary program; reserve mon & row th $w$ & as limited $t$ & 13 perc & t after cc & correcting & for the & basing at & t end-200 & & & \\
\hline${ }^{4}$ On a fiscal year basis (July-June). For example, the column ending in 20 & refer to $F Y$ & 2010/11. & Solumn 20 & 11 is there & efore the & progran & column fo & or fiscal d & data. & & \\
\hline $\begin{array}{l}{ }^{5} \text { Revenue excluding grants minus current expenditure except interest due } \\
\text { integrating militia groups) minus domestically financed capital expenditure. }\end{array}$ & d exceptio & nal expenc & iture $(\mathrm{AU}$ & peacekee & eping exp & enditure & and spen & nding on $\mathrm{c}$ & & $g$ an & \\
\hline
\end{tabular}

CInternational Monetary Fund. Not for Redistribution 
Table 3. Rwanda: Balance of Payments, 2007-15

(Millions of U.S. dollars, unless otherwise indicated)

\begin{tabular}{|c|c|c|c|c|c|c|c|c|c|c|}
\hline & \multirow[t]{2}{*}{2007} & \multirow{2}{*}{$\begin{array}{c}2008 \\
\text { Est. }\end{array}$} & \multirow{2}{*}{$\begin{array}{c}2009 \\
\text { Est. }\end{array}$} & \multicolumn{2}{|c|}{2010} & \multirow{2}{*}{$\begin{array}{l}2011 \\
\text { Proj. }\end{array}$} & \multirow{2}{*}{$\begin{array}{l}2012 \\
\text { Proj. }\end{array}$} & \multirow{2}{*}{$\begin{array}{l}2013 \\
\text { Proj. }\end{array}$} & \multirow{2}{*}{$\begin{array}{l}2014 \\
\text { Proj. }\end{array}$} & \multirow{2}{*}{$\begin{array}{l}2015 \\
\text { Proj. }\end{array}$} \\
\hline & & & & Prog. $^{8}$ & Proj. & & & & & \\
\hline Exports (f.o.b.), ${ }^{1}$ of which: & 176.8 & 267.7 & 192.7 & 240.1 & 285.5 & 284.4 & 314.0 & 345.7 & 393.1 & 447.5 \\
\hline Coffee and tea & 67.2 & 92.0 & 85.6 & 107.6 & 121.3 & 108.4 & 120.4 & 127.3 & 147.4 & 165.9 \\
\hline Minerals & 70.6 & 91.7 & 55.4 & 74.3 & 56.1 & 61.1 & 66.9 & 76.9 & 88.3 & 105.6 \\
\hline Imports (f.o.b.), of which: & 581.2 & 880.7 & $1,025.0$ & $1,146.6$ & $1,146.6$ & $1,371.0$ & $1,262.5$ & $1,250.4$ & $1,335.8$ & $1,444.0$ \\
\hline Capital goods & 152.7 & 275.5 & 278.6 & 351.2 & 278.6 & 443.7 & 332.0 & 274.4 & 306.1 & 339.7 \\
\hline Energy goods & 87.2 & 121.1 & 169.5 & 213.8 & 233.2 & 254.5 & 282.4 & 307.3 & 330.2 & 356.8 \\
\hline Trade balance & -404.4 & -613.0 & -832.3 & -906.4 & -861.1 & $-1,086.7$ & -948.5 & -904.8 & -942.7 & -996.5 \\
\hline Services (net) ${ }^{2}$ & -123.2 & -100.6 & -178.5 & -214.1 & -179.6 & -191.4 & -129.5 & -66.8 & -23.7 & 31.3 \\
\hline Of which: tourism receipts & 151.6 & 186.0 & 174.5 & 205.9 & 186.0 & 213.9 & 246.0 & 282.9 & 325.3 & 374.1 \\
\hline Income & -17.2 & -35.1 & -36.8 & -58.5 & -35.8 & -54.5 & -74.0 & -82.1 & -77.6 & -70.7 \\
\hline Of which: interest on public debt ${ }^{3}$ & -6.2 & -6.9 & -7.3 & -9.1 & -11.4 & -11.1 & -22.8 & -30.2 & -30.1 & -27.6 \\
\hline Current transfers (net) ${ }^{4}$ & 461.3 & 518.6 & 604.0 & 728.5 & 695.7 & 777.4 & 722.5 & 717.2 & 734.4 & 745.3 \\
\hline Private & 98.8 & 72.6 & 79.7 & 82.2 & 96.0 & 95.0 & 88.8 & 92.5 & 106.9 & 123.3 \\
\hline Of which: remittance inflows & 98.5 & 63.3 & 88.1 & 91.6 & 98.8 & 95.5 & 100.2 & 105.4 & 115.7 & 127.5 \\
\hline Public & 362.5 & 446.0 & 524.3 & 646.4 & 599.7 & 682.4 & 633.8 & 624.7 & 627.5 & 622.0 \\
\hline Of which: HIPC grants & 4.5 & 5.6 & 5.2 & 4.7 & 4.8 & 4.2 & 4.6 & 4.9 & 5.0 & 5.0 \\
\hline Current account balance (incl. official transfers) & -83.4 & -230.1 & -443.6 & -450.5 & -380.8 & -555.1 & -429.5 & -336.4 & -309.6 & -290.6 \\
\hline Current account balance (excl. official transfers) & -445.9 & -676.1 & -967.9 & $-1,096.9$ & -980.5 & $-1,237.5$ & $-1,063.2$ & -961.1 & -937.1 & -912.6 \\
\hline Capital account & 92.0 & 210.1 & 200.0 & 207.5 & 207.5 & 181.8 & 188.7 & 185.7 & 183.4 & 181.0 \\
\hline Project grants & 92.0 & 210.1 & 200.0 & 207.5 & 207.5 & 181.8 & 188.7 & 185.7 & 183.4 & 181.0 \\
\hline Financial account & 104.7 & 106.1 & 312.2 & 246.5 & 163.9 & 404.0 & 230.2 & 153.1 & 169.8 & 158.4 \\
\hline Direct investment & 82.3 & 103.4 & 118.7 & 102.6 & 66.4 & 111.7 & 94.6 & 113.5 & 135.7 & 162.3 \\
\hline Public sector capital & 80.4 & 104.8 & 169.0 & 161.9 & 81.7 & 227.0 & 129.9 & 43.2 & 12.0 & -1.8 \\
\hline Long-term borrowing $^{5}$ & 88.7 & 112.2 & 75.7 & 176.4 & 96.4 & 259.0 & 157.3 & 84.6 & 70.0 & 60.9 \\
\hline Scheduled amortization ${ }^{6}$ & -8.3 & -7.5 & -7.5 & -14.5 & -14.7 & -32.1 & -27.4 & -41.5 & -58.0 & -62.7 \\
\hline SDR allocation & & & 100.7 & & & & & & & \\
\hline Other capital $^{7}$ & -58.0 & -102.0 & 24.6 & -18.0 & 15.8 & 65.3 & 5.7 & -3.5 & 22.1 & -2.1 \\
\hline Capital and financial account balance & 196.7 & 316.1 & 512.2 & 454.0 & 371.4 & 585.8 & 418.9 & 338.9 & 353.2 & 339.4 \\
\hline Errors and omissions & -5.4 & -21.3 & 76.2 & 0.0 & 0.0 & 0.0 & 0.0 & 0.0 & 0.0 & 0.0 \\
\hline Overall balance & 107.9 & 64.7 & 144.8 & 3.5 & -9.4 & 30.7 & -10.5 & 2.4 & 43.6 & 48.8 \\
\hline Financing & -107.9 & -64.7 & -144.8 & -3.5 & 9.4 & -30.7 & 10.5 & -2.4 & -43.6 & -48.9 \\
\hline Change in net foreign assets of NBR (increase -) & -107.9 & -64.7 & -144.8 & -3.5 & 9.4 & -30.7 & 10.5 & -2.4 & -43.6 & -48.9 \\
\hline Net credit from the Fund & 3.5 & 3.6 & 3.6 & -0.1 & -0.1 & -0.6 & -1.0 & -1.7 & -2.4 & -2.9 \\
\hline Disbursements/purchases & 3.5 & 3.6 & 3.6 & 0.0 & 0.0 & 0.0 & 0.0 & 0.0 & 0.0 & 0.0 \\
\hline Repayments/repurchases & 0.0 & 0.0 & 0.0 & -0.1 & -0.1 & -0.6 & -1.0 & -1.7 & -2.4 & -2.9 \\
\hline Change in other gross official reserves (increase -) & -112.7 & -44.1 & -145.8 & -9.0 & 5.0 & -30.1 & 11.5 & -0.7 & -41.1 & -46.0 \\
\hline Change in other foreign liabilities (increase + ) & 1.4 & -24.2 & -2.6 & 5.6 & 4.5 & 0.0 & 0.0 & 0.0 & 0.0 & 0.0 \\
\hline Change in arrears (decrease -) & 0.0 & 0.0 & 0.0 & 0.0 & 0.0 & 0.0 & 0.0 & 0.0 & 0.0 & 0.0 \\
\hline Exceptional financing & 0.0 & 0.0 & 0.0 & 0.0 & 0.0 & 0.0 & 0.0 & 0.0 & 0.0 & 0.0 \\
\hline Financing need & 0.0 & 0.0 & 0.0 & 0.0 & 0.0 & 0.0 & 0.0 & 0.0 & 0.0 & 0.0 \\
\hline Identified financing & 0.0 & 0.0 & 0.0 & 0.0 & 0.0 & 0.0 & 0.0 & 0.0 & 0.0 & 0.0 \\
\hline Financing gap & 0.0 & 0.0 & 0.0 & 0.0 & 0.0 & 0.0 & 0.0 & 0.0 & 0.0 & 0.0 \\
\hline \multicolumn{11}{|l|}{ Memorandum items: } \\
\hline \multicolumn{11}{|l|}{ Current account deficit (percent of GDP) } \\
\hline Excluding official transfers & -11.9 & -14.4 & -18.6 & -19.3 & -17.3 & -20.2 & -15.9 & -13.2 & -11.8 & -10.6 \\
\hline Including official transfers & -2.2 & -4.9 & -8.5 & -7.9 & -6.7 & -9.0 & -6.4 & -4.6 & -3.9 & -3.4 \\
\hline Gross official reserves (including SDR allocation) & 552.4 & 596.4 & 742.2 & 744.3 & 737.2 & 767.3 & 755.7 & 756.4 & 797.6 & 843.6 \\
\hline Gross official reserves (months of prospective imports of G\&NFS & 4.7 & 4.6 & 5.5 & 4.8 & 4.6 & 5.2 & 5.1 & 4.8 & 4.7 & 4.7 \\
\hline Overall balance (percent of GDP) & 2.9 & 1.4 & 2.8 & 0.1 & -0.2 & 0.5 & -0.2 & 0.0 & 0.6 & 0.6 \\
\hline
\end{tabular}

Sources: Rwandan authorities; and IMF staff estimates and projections.

${ }^{1}$ From 2010 onwards includes the results of the informal cross-border trade survey.

${ }^{2}$ Revision of methodology resulted in sharp increase of tourism revenues from 2008, thus increasing export of services.

${ }^{3}$ Including interest due to the Fund.

${ }^{4}$ Current transfers include disbursed budgetary and HIPC grants and humanitarian and technical assistance.

${ }^{5}$ Includes project and budgetary loans.

${ }^{6}$ Excluding payments to the Fund.

${ }^{7}$ Other capital includes long-term private capital, commercial credit, change in the net foreign assets of commercial banks, and unrecorded imports

${ }^{8}$ IMF Country Report No. 10/200. 
Table 4. Rwanda: Operations of the Central Government, Fiscal Year Basis ${ }^{1}, 2006 / 07-14 / 15$

\begin{tabular}{|c|c|c|c|c|c|c|c|c|c|c|}
\hline & $2006 / 07$ & $2007 / 08$ & $2008 / 09$ & $2009 / 10$ & $2009 / 10$ & $2010 / 11$ & $2011 / 12$ & $2012 / 13$ & $2013 / 14$ & $2014 / 15$ \\
\hline & & & & Proj. $^{6}$ & Prel. & Prog. & Proj. & Proj. & Proj. & Proj. \\
\hline & \multicolumn{10}{|c|}{ (Billions of Rwandan francs) } \\
\hline Revenue and grants & 388.0 & 518.2 & 670.7 & 779.6 & 800.7 & 825.4 & 966.7 & $1,077.0$ & $1,177.2$ & $1,286.5$ \\
\hline Total revenue & 233.2 & 290.3 & 413.0 & 385.1 & 391.4 & 471.1 & 536.0 & 626.7 & 719.3 & 815.7 \\
\hline Tax revenue & 217.6 & 272.4 & 361.4 & 369.3 & 376.4 & 449.1 & 508.9 & 591.6 & 679.9 & 771.7 \\
\hline Direct taxes & 73.6 & 103.3 & 130.1 & 144.5 & 148.8 & 175.8 & 199.4 & 231.5 & 269.4 & 307.3 \\
\hline Taxes on goods and services & 109.8 & 135.0 & 179.3 & 191.2 & 195.0 & 234.3 & 265.4 & 308.3 & 355.6 & 403.7 \\
\hline Taxes on international trade & 34.2 & 34.2 & 52.0 & 33.6 & 32.6 & 39.0 & 44.1 & 51.8 & 54.9 & 60.6 \\
\hline Nontax revenue & 15.7 & 17.8 & 51.7 & 15.8 & 15.0 & 22.1 & 27.1 & 35.1 & 39.4 & 44.1 \\
\hline Grants & 154.8 & 227.9 & 257.7 & 394.5 & 409.3 & 354.3 & 430.7 & 450.3 & 458.0 & 470.7 \\
\hline Budgetary grants & 101.4 & 168.1 & 167.0 & 268.1 & 283.0 & 237.5 & 317.0 & 332.8 & 338.6 & 349.3 \\
\hline Of which: HIPC Initiative assistance & 7.1 & 1.6 & 2.4 & 3.0 & 0.0 & $1.8^{4}$ & $\ldots$ & $\ldots$ & $\ldots$ & $\ldots$ \\
\hline Capital grants & 53.4 & 59.8 & 90.7 & 126.4 & 126.3 & 116.8 & 113.7 & 117.5 & 119.4 & 121.4 \\
\hline Project grants & 53.4 & 59.8 & 90.7 & 126.4 & 0.0 & 116.8 & 113.7 & 117.5 & 119.4 & 121.4 \\
\hline Total expenditure and net lending & 414.2 & 521.8 & 731.2 & 814.9 & 804.2 & 949.2 & $1,028.1$ & $1,105.7$ & $1,197.6$ & $1,306.8$ \\
\hline Current expenditure & 266.5 & 349.0 & 401.7 & 467.7 & 459.2 & 514.2 & 602.8 & 685.1 & 767.4 & 856.2 \\
\hline Of which: priority & 139.7 & 151.7 & 232.2 & 280.4 & 280.4 & 297.6 & $\ldots$ & $\ldots$ & $\ldots$ & $\ldots$ \\
\hline Wages and salaries & 71.5 & 76.3 & 90.8 & 108.2 & 106.9 & 120.5 & 130.1 & 146.4 & 165.1 & 184.9 \\
\hline Civil & 48.5 & 55.5 & 66.1 & 78.9 & 77.5 & 85.8 & 94.0 & 105.8 & 117.0 & 131.1 \\
\hline Defense & 22.9 & 20.8 & 24.7 & 29.3 & 29.4 & 34.7 & 36.1 & 40.6 & 48.1 & 53.9 \\
\hline Purchases of goods and services & 66.4 & 81.6 & 103.2 & 106.8 & 106.3 & 120.0 & 156.7 & 179.2 & 203.6 & 227.4 \\
\hline Civil & 57.5 & 70.4 & 82.9 & 94.5 & 94.3 & 101.0 & 135.3 & 155.3 & 174.7 & 195.4 \\
\hline Defense & 8.9 & 11.2 & 20.2 & 12.3 & 12.0 & 16.0 & 21.4 & 23.9 & 28.9 & 32.0 \\
\hline Interest payments & 12.8 & 13.6 & 11.4 & 13.4 & 14.7 & 13.5 & 14.4 & 15.8 & 16.2 & 18.4 \\
\hline Domestic debt & 8.7 & 11.1 & 7.4 & 8.6 & 10.1 & 9.0 & 9.3 & 9.7 & 10.2 & 11.4 \\
\hline External debt & 4.1 & 2.4 & 4.0 & 4.8 & 4.6 & 4.5 & 5.1 & 6.1 & 6.0 & 7.0 \\
\hline Transfers & 82.4 & 121.8 & 141.6 & 184.7 & 179.6 & 193.2 & 233.5 & 276.6 & 313.3 & 348.0 \\
\hline Exceptional expenditure & 33.5 & 55.7 & 54.7 & 54.7 & 51.6 & 67.0 & 68.1 & 67.1 & 69.1 & 77.4 \\
\hline Capital expenditure & 131.8 & 188.2 & 306.6 & 308.8 & 316.7 & 402.8 & 404.0 & 398.3 & 415.3 & 440.9 \\
\hline Of which: priority & 28.0 & 38.9 & 124.4 & 129.2 & 129.2 & 158.9 & & & ... & ... \\
\hline Domestic & 42.5 & 87.6 & 139.7 & 152.4 & 159.3 & 223.1 & 210.9 & 231.7 & 254.1 & 277.0 \\
\hline Foreign & 89.3 & 100.6 & 167.0 & 156.4 & 157.4 & 179.7 & 193.1 & 166.6 & 161.2 & 163.9 \\
\hline $\begin{array}{l}\text { Net lending and privatization receipts } \\
\text { of which: }\end{array}$ & 15.9 & -15.4 & 22.9 & 38.4 & 28.2 & 32.3 & 21.3 & 22.3 & 14.9 & 9.7 \\
\hline Priority spending & 4.8 & 3.9 & 2.1 & 2.9 & 2.9 & 3.6 & $\ldots$ & $\ldots$ & $\ldots$ & $\ldots$ \\
\hline Kigali Convention Center & 0.0 & 0.0 & 0.0 & 18.0 & 18.0 & 0.0 & 0.0 & 0.0 & 0.0 & 0.0 \\
\hline RwandAir & 0.0 & 0.0 & 0.0 & 12.0 & 4.5 & 25.0 & 11.7 & 7.1 & 0.0 & 0.0 \\
\hline Primary balance ${ }^{2}$ & -29.5 & -77.1 & -62.2 & -167.0 & -160.8 & -185.6 & -195.2 & -207.2 & -216.9 & -221.6 \\
\hline Domestic fiscal balance ${ }^{3}$ & -87.5 & -128.5 & -147.2 & -268.7 & -250.7 & -293.9 & -293.9 & -306.3 & -311.1 & -320.2 \\
\hline Excluding demobilization and peacekeeping expenditures & -76.6 & -112.0 & -121.8 & -245.1 & -224.3 & -250.6 & -278.4 & -306.3 & -311.1 & -320.2 \\
\hline \multicolumn{11}{|l|}{ Overall deficit (payment order) } \\
\hline After grants & -26.1 & -3.6 & -60.5 & -35.4 & -3.5 & -123.8 & -61.4 & -28.7 & -20.3 & -20.3 \\
\hline Before grants & -180.9 & -231.6 & -318.1 & -429.9 & -412.8 & -478.1 & -492.1 & -479.0 & -478.3 & -491.0 \\
\hline Change in arrears ${ }^{4}$ & -7.0 & -8.6 & -9.0 & -8.4 & -11.2 & -11.0 & -8.0 & -8.0 & -8.0 & -8.0 \\
\hline Overall deficit (incl. grants, cash basis) & -33.1 & -12.2 & -69.4 & -43.8 & -14.7 & -134.8 & -69.4 & -36.7 & -28.3 & -28.3 \\
\hline Financing & 41.2 & 11.3 & 69.4 & 43.8 & 14.7 & 134.8 & 69.4 & 36.7 & 28.3 & 28.3 \\
\hline Foreign financing (net) & 39.2 & 42.8 & 72.5 & 24.7 & 26.1 & 54.8 & 69.4 & 36.7 & 28.2 & 28.1 \\
\hline Drawings & 44.7 & 47.9 & 77.0 & 30.0 & 31.1 & 62.9 & 79.5 & 49.1 & 41.8 & 42.5 \\
\hline Budgetary loans & 8.8 & 5.2 & 0.7 & 0.0 & 0.0 & 0.0 & 0.0 & 0.0 & 0.0 & 0.0 \\
\hline Project loans & 36.0 & 42.7 & 76.3 & 30.0 & 31.1 & 62.9 & 79.5 & 49.1 & 41.8 & 42.5 \\
\hline Amortization & -5.6 & -5.1 & -4.4 & -5.3 & -5.0 & -8.1 & -10.1 & -12.4 & -13.6 & -14.4 \\
\hline Net domestic financing & 2.1 & -31.5 & -3.1 & 19.0 & -11.4 & 80.1 & 0.0 & 0.0 & 0.1 & 0.2 \\
\hline Net credit from banking system & -7.2 & -13.4 & 18.0 & 20.8 & 8.4 & 64.3 & 22.4 & 0.0 & 0.0 & 0.0 \\
\hline Nonbank sector & 9.3 & -18.1 & -21.2 & -1.8 & -18.1 & 18.1 & -22.4 & 0.0 & 0.0 & 0.0 \\
\hline Errors and omissions 5 & 8.1 & -0.9 & 0.0 & 0.0 & -1.7 & 0.0 & -0.1 & 0.0 & 0.0 & 0.0 \\
\hline \multicolumn{11}{|l|}{ Memo: } \\
\hline Priority spending & 172.5 & 194.5 & 358.7 & 412.5 & 412.5 & 460.1 & $\ldots$ & $\ldots$ & $\ldots$ & $\ldots$ \\
\hline
\end{tabular}

Sources: Rwandan authorities and IMF staff estimates and projections

1 Fiscal year runs from July to June.

2 Total revenue minus noninterest current expenditure (excluding exceptional expenditure) minus domestically financed capital investment.

${ }^{3}$ Total revenue minus current expenditure (excluding interest ion external debt), domestically financed capital expenditure, and net lending.

${ }^{4} \mathrm{~A}$ negative sign indicates a reduction.

${ }^{5}$ A negative number implies an underestimate of financing.

${ }^{6}$ IMF Country Report No. 10/200. 
Table 4. Rwanda: Operations of the Central Government, Fiscal Year Basis ${ }^{1}, 2006 / 07-14 / 15$ (continued)

\begin{tabular}{|c|c|c|c|c|c|c|c|c|c|c|}
\hline & $2006 / 07$ & $2007 / 08$ & $2008 / 09$ & $2009 / 10$ & $2009 / 10$ & $2010 / 11$ & $2011 / 12$ & $2012 / 13$ & $2013 / 14$ & $2014 / 15$ \\
\hline & & & & Proj. $^{6}$ & Prel. & Prog. & Proj. & Proj. & Proj. & Proj. \\
\hline & \multicolumn{10}{|c|}{ (In percent of fiscal year GDP) } \\
\hline Revenue and grants & 20.6 & 22.5 & 24.3 & 24.8 & 25.7 & 23.8 & 24.8 & 24.6 & 23.9 & 23.4 \\
\hline Total revenue & 12.4 & 12.6 & 14.9 & 12.2 & 12.5 & 13.6 & 13.7 & 14.3 & 14.6 & 14.8 \\
\hline Tax revenue & 11.6 & 11.8 & 13.1 & 11.7 & 12.1 & 12.9 & 13.0 & 13.5 & 13.8 & 14.0 \\
\hline Direct taxes & 3.9 & 4.5 & 4.7 & 4.6 & 4.8 & 5.1 & 5.1 & 5.3 & 5.5 & 5.6 \\
\hline Taxes on goods and services & 5.8 & 5.8 & 6.5 & 6.1 & 6.2 & 6.7 & 6.8 & 7.0 & 7.2 & 7.3 \\
\hline Taxes on international trade & 1.8 & 1.5 & 1.9 & 1.1 & 1.0 & 1.1 & 1.1 & 1.2 & 1.1 & 1.1 \\
\hline Nontax revenue & 0.8 & 0.8 & 1.9 & 0.5 & 0.5 & 0.6 & 0.7 & 0.8 & 0.8 & 0.8 \\
\hline ID receipts & $\ldots$ & $\ldots$ & 0.1 & 0.0 & 0.0 & $\ldots$ & $\ldots$ & $\ldots$ & $\ldots$ & $\ldots$ \\
\hline Grants & 8.2 & 9.9 & 9.3 & 12.5 & 13.1 & 10.2 & 11.0 & 10.3 & 9.3 & 8.5 \\
\hline Budgetary grants & 5.4 & 7.3 & 6.0 & 8.5 & 9.1 & 6.8 & 8.1 & 7.6 & 6.9 & 6.3 \\
\hline Of which: HIPC Initiative assistance & 0.4 & 0.1 & 0.1 & 0.1 & 0.0 & 0.1 & $\ldots$ & & $\ldots$ & $\ldots$ \\
\hline Capital grants & 2.8 & 2.6 & 3.3 & 4.0 & 4.0 & 3.4 & 2.9 & 2.7 & 2.4 & 2.2 \\
\hline Project grants & 2.8 & 2.6 & 3.3 & 4.0 & 0.0 & 3.4 & 2.9 & 2.7 & 2.4 & 2.2 \\
\hline Total expenditure and net lending & 22.0 & 22.6 & 26.4 & 25.9 & 25.8 & 27.3 & 26.4 & 25.2 & 24.4 & 23.7 \\
\hline Current expenditure & 14.2 & 15.1 & 14.5 & 14.9 & 14.7 & 14.8 & 15.5 & 15.6 & 15.6 & 15.5 \\
\hline Of which: priority & 7.4 & 6.6 & 8.4 & 8.9 & 9.0 & 8.6 & $\ldots$ & $\ldots$ & $\ldots$ & $\ldots$ \\
\hline Wages and salaries & 3.8 & 3.3 & 3.3 & 3.4 & 3.4 & 3.5 & 3.3 & 3.3 & 3.4 & 3.4 \\
\hline Civil & 2.6 & 2.4 & 2.4 & 2.5 & 2.5 & 2.5 & 2.4 & 2.4 & 2.4 & 2.4 \\
\hline Defense & 1.2 & 0.9 & 0.9 & 0.9 & 0.9 & 1.0 & 0.9 & 0.9 & 1.0 & 1.0 \\
\hline Purchases of goods and services & 3.5 & 3.5 & 3.7 & 3.4 & 3.4 & 3.5 & 4.0 & 4.1 & 4.1 & 4.1 \\
\hline Civil & 3.1 & 3.0 & 3.0 & 3.0 & 3.0 & 2.9 & 3.5 & 3.5 & 3.6 & 3.5 \\
\hline Defense & 0.5 & 0.5 & 0.7 & 0.4 & 0.4 & 0.5 & 0.5 & 0.5 & 0.6 & 0.6 \\
\hline Interest payments & 0.7 & 0.6 & 0.4 & 0.4 & 0.5 & 0.4 & 0.4 & 0.4 & 0.3 & 0.3 \\
\hline Domestic debt & 0.5 & 0.5 & 0.3 & 0.3 & 0.3 & 0.3 & 0.2 & 0.2 & 0.2 & 0.2 \\
\hline External debt & 0.2 & 0.1 & 0.1 & 0.2 & 0.1 & 0.1 & 0.1 & 0.1 & 0.1 & 0.1 \\
\hline Transfers & 4.4 & 5.3 & 5.1 & 5.9 & 5.8 & 5.6 & 6.0 & 6.3 & 6.4 & 6.3 \\
\hline Exceptional expenditure & 1.8 & 2.4 & 2.0 & 1.7 & 1.7 & 1.9 & 1.7 & 1.5 & 1.4 & 1.4 \\
\hline Capital expenditure & 7.0 & 8.2 & 11.1 & 9.8 & 10.1 & 11.6 & 10.4 & 9.1 & 8.4 & 8.0 \\
\hline Of which: priority & 1.5 & 1.7 & 4.5 & 4.1 & 4.1 & 4.6 & $\ldots$ & $\ldots$ & $\ldots$ & $\ldots$ \\
\hline Domestic & 2.3 & 3.8 & 5.1 & 4.8 & 5.1 & 6.4 & 5.4 & 5.3 & 5.2 & 5.0 \\
\hline Foreign & 4.7 & 4.4 & 6.0 & 5.0 & 5.0 & 5.2 & 4.9 & 3.8 & 3.3 & 3.0 \\
\hline $\begin{array}{l}\text { Net lending and privatization receipts } \\
\text { of which: }\end{array}$ & 0.8 & -0.7 & 0.8 & 1.2 & 0.9 & 0.9 & 0.5 & 0.5 & 0.3 & 0.2 \\
\hline Priority spending & 0.3 & 0.2 & 0.1 & 0.1 & 0.1 & 0.1 & $\ldots$ & $\ldots$ & $\ldots$ & $\ldots$ \\
\hline Kigali Convention Center & 0.0 & 0.0 & 0.0 & 0.6 & 0.6 & 0.0 & 0.0 & 0.0 & 0.0 & 0.0 \\
\hline RwandAir & 0.0 & 0.0 & 0.0 & 0.4 & 0.1 & 0.7 & 0.3 & 0.2 & 0.0 & 0.0 \\
\hline Primary balance $^{2}$ & -1.6 & -3.3 & -2.2 & -5.3 & -5.2 & -5.3 & -5.0 & -4.7 & -4.4 & -4.0 \\
\hline Domestic fiscal balance $^{3}$ & -4.6 & -5.6 & -5.3 & -8.5 & -8.0 & -8.5 & -7.5 & -7.0 & -6.3 & -5.8 \\
\hline Excluding demobilization and peacekeeping expenditures & -4.1 & -4.9 & -4.4 & -7.8 & -7.2 & -7.2 & -7.1 & -7.0 & -6.3 & -5.8 \\
\hline \multicolumn{11}{|l|}{ Overall deficit (payment order) } \\
\hline After grants & -1.4 & -0.2 & -2.2 & -1.1 & -0.1 & -3.6 & -1.6 & -0.7 & -0.4 & -0.4 \\
\hline Before grants & -9.6 & -10.0 & -11.5 & -13.7 & -13.2 & -13.8 & -12.6 & -10.9 & -9.7 & -8.9 \\
\hline Change in arrears ${ }^{4}$ & -0.4 & -0.4 & -0.3 & -0.3 & -0.4 & -0.3 & -0.2 & -0.2 & -0.2 & -0.1 \\
\hline Overall deficit (incl. grants, cash basis) & -1.8 & -0.5 & -2.5 & -1.4 & -0.5 & -3.9 & -1.8 & -0.8 & -0.6 & -0.5 \\
\hline Financing & 2.2 & 0.5 & 2.5 & 1.4 & 0.5 & 3.9 & 1.8 & 0.8 & 0.6 & 0.5 \\
\hline Foreign financing (net) & 2.1 & 1.9 & 2.6 & 0.8 & 0.8 & 1.6 & 1.8 & 0.8 & 0.6 & 0.5 \\
\hline Drawings & 2.4 & 2.1 & 2.8 & 1.0 & 1.0 & 1.8 & 2.0 & 1.1 & 0.8 & 0.8 \\
\hline Budgetary loans & 0.5 & 0.2 & 0.0 & 0.0 & 0.0 & 0.0 & 0.0 & 0.0 & 0.0 & 0.0 \\
\hline Project loans & 1.9 & 1.9 & 2.8 & 1.0 & 1.0 & 1.8 & 2.0 & 1.1 & 0.8 & 0.8 \\
\hline Amortization & -0.3 & -0.2 & -0.2 & -0.2 & -0.2 & -0.2 & -0.3 & -0.3 & -0.3 & -0.3 \\
\hline Net domestic financing & 0.1 & -1.4 & -0.1 & 0.6 & -0.4 & 2.3 & 0.0 & 0.0 & 0.0 & 0.0 \\
\hline Net credit from banking system & -0.4 & -0.6 & 0.7 & 0.7 & 0.3 & 1.9 & 0.6 & 0.0 & 0.0 & 0.0 \\
\hline Nonbank sector & 0.5 & -0.8 & -0.8 & -0.1 & -0.6 & 0.5 & -0.6 & 0.0 & 0.0 & 0.0 \\
\hline Errors and omissions ${ }^{5}$ & 0.4 & 0.0 & 0.0 & 0.0 & -0.1 & 0.0 & 0.0 & 0.0 & 0.0 & 0.0 \\
\hline \multicolumn{11}{|l|}{ Memo: } \\
\hline Priority spending & 9.2 & 8.4 & 13.0 & 13.1 & 13.2 & 13.2 & $\ldots$ & $\ldots$ & $\ldots$ & $\ldots$ \\
\hline GDP (Billions of RwF), FY basis & 1,883 & 2,307 & 2,765 & 3,149 & 3,121 & 3,475 & 3,901 & 4,385 & 4,917 & 5,507 \\
\hline
\end{tabular}

Sources: Rwandan authorities and IMF staff estimates and projections.

1 Fiscal year runs from July to June.

2 Total revenue minus noninterest current expenditure (excluding exceptional expenditure) minus domestically financed capital investment.

${ }^{3}$ Total revenue minus current expenditure (excluding interest on external debt), domestically financed capital expenditure, and net lending

${ }^{4}$ A negative sign indicates a reduction.

A negative number implies an underestimate of financing

${ }^{6}$ IMF Country Report No. 10/200. 
Table 5. Rwanda: Monetary Survey ${ }^{1}, 2006-13$

\begin{tabular}{|c|c|c|c|c|c|c|c|c|c|c|c|c|c|c|c|c|c|c|}
\hline & \multirow[t]{3}{*}{2006} & \multirow[t]{3}{*}{2007} & \multirow[t]{3}{*}{2008} & \multicolumn{4}{|c|}{2009} & \multicolumn{5}{|c|}{2010} & \multicolumn{4}{|c|}{2011} & \multirow{3}{*}{$\begin{array}{c}2012 \\
\text { Dec } \\
\text { Proj. }\end{array}$} & \multirow{3}{*}{$\begin{array}{r}2013 \\
\text { Dec } \\
\text { Proi }\end{array}$} \\
\hline & & & & March & June & Sept & Dec & March & June & June & Sept & Dec. & March & June & Sept & Dec & & \\
\hline & & & & & & & Est. & Est. & Est. & Prog. $^{7}$ & Prog. & Prog. & $\begin{array}{l}\text { Prog. } \\
\end{array}$ & Prog. & Prog. & Prog. & & \\
\hline & & & & \multicolumn{15}{|c|}{ (Billions of Rwanda francs) } \\
\hline \multicolumn{19}{|l|}{ Monetary authorities } \\
\hline Net Foreign Assets ${ }^{2}$ & 225.0 & 281.8 & 325.6 & 272.2 & 312.6 & 344.5 & 358.0 & 322.6 & 384.7 & 369.3 & 390.5 & 352.6 & 353.2 & 318.9 & 346.9 & 369.7 & 364.1 & 365.5 \\
\hline Foreign assets & 241.2 & 300.6 & 333.4 & 280.7 & 323.9 & 412.1 & 424.0 & 386.9 & 447.2 & 437.9 & 458.3 & 421.1 & 421.7 & 387.4 & 415.5 & 438.3 & 431.7 & 432.1 \\
\hline Foreign liabilities $^{3}$ & 16.3 & 18.8 & 7.8 & 8.5 & 11.3 & 67.6 & 66.0 & 64.2 & 62.5 & 68.5 & 67.8 & 68.5 & 68.5 & 68.5 & 68.5 & 68.5 & 67.6 & 66.6 \\
\hline Net domestic assets & -153.1 & -187.9 & -209.6 & -158.5 & -203.0 & -229.5 & -241.6 & -206.1 & -277.5 & -248.7 & -264.8 & -222.6 & -219.5 & -179.6 & -203.2 & -221.6 & -195.3 & -174.2 \\
\hline Domestic credit & -119.4 & -152.6 & -168.7 & -116.4 & -154.9 & -188.2 & -201.5 & -157.3 & -211.9 & -208.0 & -210.5 & -170.3 & -165.2 & -125.3 & -148.9 & -167.3 & -141.0 & -119.9 \\
\hline Government (net) & -71.6 & -98.8 & -158.5 & -122.5 & -131.0 & -145.5 & -143.9 & -110.2 & -143.2 & -149.0 & -157.7 & -124.8 & -112.9 & -91.0 & -97.1 & -130.4 & -130.4 & -130.4 \\
\hline Claims & 41.8 & 41.2 & 39.7 & 45.2 & 39.4 & 40.9 & 50.2 & 60.9 & 39.3 & 38.5 & 39.3 & 68.3 & 50.9 & 49.0 & 37.0 & 37.0 & 37.0 & 37.0 \\
\hline Deposits (excluding autonomous bodies) ${ }^{3}$ & 113.4 & 140.0 & 198.3 & 167.7 & 170.3 & 186.4 & 193.7 & 171.1 & 182.5 & 187.5 & 197.0 & 193.1 & 163.8 & 140.0 & 134.1 & 167.4 & 167.4 & 167.4 \\
\hline Public nongovernment deposits (-) & -2.0 & -1.3 & -0.5 & -0.4 & -0.6 & -1.9 & -1.9 & -1.9 & -4.3 & -1.9 & -4.3 & -1.9 & -1.9 & -1.9 & -1.9 & -1.9 & -1.9 & -1.9 \\
\hline Nongovernment credit & -45.8 & -52.5 & -9.7 & 6.5 & -23.3 & -40.8 & -56.6 & -45.2 & -64.4 & -57.1 & -48.5 & -43.6 & -50.4 & -32.4 & -49.9 & -35.0 & -8.7 & 12.4 \\
\hline Private sector & 3.5 & 4.8 & 5.4 & 4.6 & 5.0 & 5.2 & 7.9 & 5.3 & 5.4 & 8.0 & 7.5 & 9.0 & 10.0 & 10.0 & 10.0 & 10.0 & 10.0 & 10.0 \\
\hline Public enterprises & -- & -- & -- & -- & -- & -- & -- & - & -- & -- & -- & -- & - & -- & - & - & -- & -- \\
\hline Commercial banks & -49.3 & -57.3 & -15.1 & 0.9 & -30.4 & -48.0 & -64.0 & -52.9 & -71.7 & -65.1 & -56.0 & -52.6 & -60.4 & -42.4 & -59.9 & -45.0 & -18.7 & 2.4 \\
\hline Discount window & 1.2 & 1.3 & 1.5 & - & - & - & 9.5 & 11.2 & 10.7 & 9.5 & 12.6 & 8.0 & 11.0 & 12.0 & 12.0 & 12.0 & 10.0 & 10.0 \\
\hline Money market (- = absorption) & -50.5 & -58.6 & -16.6 & - & -33.5 & -53.9 & -73.5 & -64.9 & -85.3 & -74.6 & -68.6 & -60.6 & -71.4 & -54.4 & -71.9 & -57.0 & -28.7 & -7.6 \\
\hline Other items (net; asset +) & -33.8 & -35.4 & -41.0 & -42.1 & -47.9 & -41.3 & -40.2 & -48.8 & -65.5 & -40.7 & -54.3 & -52.3 & -54.3 & -54.3 & -54.3 & -54.3 & -54.3 & -54.3 \\
\hline Reserve money ${ }^{4}$ & 71.8 & 93.9 & 116.0 & 113.7 & 109.6 & 115.0 & 116.4 & 116.6 & 118.9 & 122.5 & 125.7 & 130.0 & 133.7 & 139.3 & 143.7 & 148.1 & 168.8 & 191.3 \\
\hline Currency in circulation & 54.6 & 67.3 & 80.9 & 66.3 & 72.1 & 69.4 & 77.0 & 77.0 & 77.0 & 85.3 & 81.8 & 92.9 & 99.3 & 102.6 & 105.6 & 108.8 & 116.7 & 130.6 \\
\hline Commercial bank reserves & 15.1 & 24.0 & 32.7 & 43.5 & 32.6 & 40.8 & 24.1 & 30.9 & 24.2 & 30.2 & 42.3 & 36.4 & 32.5 & 33.2 & 36.2 & 37.4 & 50.3 & 58.8 \\
\hline Nonbank deposits & 2.1 & 2.6 & 2.3 & 3.9 & 4.9 & 4.8 & 6.1 & 2.4 & 0.7 & 5.1 & 1.6 & 0.7 & 1.9 & 3.5 & 1.9 & 1.9 & 1.9 & 1.9 \\
\hline Of which: autonomous public agencies & 0.4 & 0.1 & - & - & - & -- & - & - & - & -- & -1.0 & -1.0 & - & - & - & - & 1.0 & 2.0 \\
\hline \multicolumn{19}{|l|}{ Commercial banks } \\
\hline Net foreign assets & 60.1 & 69.6 & 78.2 & 76.5 & 76.8 & 79.5 & 83.7 & 85.1 & 78.1 & 83.7 & 94.3 & 95.0 & 94.9 & 89.2 & 88.0 & 97.5 & 97.5 & 97.5 \\
\hline Foreign assets & 70.9 & 86.8 & 96.8 & 97.2 & 99.7 & 101.3 & 107.5 & 107.8 & 98.9 & 107.5 & 114.1 & 121.7 & 127.4 & 121.7 & 120.5 & 130.0 & 130.0 & 130.0 \\
\hline Foreign liabilities & 10.8 & 17.2 & 18.6 & 20.7 & 22.8 & 21.8 & 23.8 & 22.7 & 20.9 & 23.8 & 19.8 & 26.7 & 32.5 & 32.5 & 32.5 & 32.5 & 32.5 & 32.5 \\
\hline Reserves & 15.1 & 24.0 & 32.7 & 43.5 & 32.6 & 40.8 & 33.7 & 45.6 & 34.8 & 40.7 & 54.6 & 45.3 & 44.8 & 45.6 & 48.8 & 50.0 & 62.3 & 70.8 \\
\hline NBR deposits & 11.3 & 18.6 & 25.1 & 33.0 & 23.0 & 30.1 & 24.1 & 32.8 & 24.2 & 30.2 & 42.3 & 33.0 & 32.5 & 33.2 & 36.2 & 37.4 & 50.3 & 58.8 \\
\hline Required reserves & 18.8 & 24.4 & 34.2 & 20.3 & 21.1 & 22.5 & 22.8 & 23.7 & 24.6 & 26.6 & 28.1 & 28.4 & 30.1 & 30.2 & 31.8 & 32.2 & 35.1 & 39.3 \\
\hline Excess reserves & -7.5 & -5.8 & -9.1 & 12.7 & 1.9 & 7.6 & 1.3 & 9.1 & -0.3 & 3.7 & 14.1 & 4.6 & 2.4 & 2.9 & 4.4 & 5.2 & 15.2 & 19.5 \\
\hline Cash in vault & 3.8 & 5.4 & 7.6 & 10.6 & 9.6 & 10.7 & 9.5 & 12.8 & 10.6 & 10.5 & 12.3 & 12.3 & 12.3 & 12.4 & 12.6 & 12.6 & 12.0 & 12.0 \\
\hline Net credit from NBR (rediscount; liability -) & 49.3 & 57.3 & 15.1 & -0.9 & 30.4 & 48.0 & 64.0 & 52.9 & 71.7 & 65.1 & 56.0 & 52.6 & 60.4 & 42.4 & 59.9 & 45.0 & 18.7 & -2.4 \\
\hline Domestic credit & 158.7 & 218.5 & 352.9 & 339.1 & 315.8 & 326.7 & 354.6 & 351.3 & 383.2 & 373.0 & 398.8 & 420.0 & 455.5 & 473.6 & 467.1 & 479.0 & 561.4 & 659.0 \\
\hline Government (net) & -2.3 & 25.4 & 16.2 & 3.0 & -8.3 & 6.6 & -0.4 & -9.7 & 16.4 & 28.6 & 18.7 & 28.6 & 28.6 & 28.6 & -0.4 & -0.4 & -0.4 & -0.4 \\
\hline Credit & 25.6 & 40.6 & 29.3 & 15.2 & 15.2 & 15.2 & 31.6 & 31.6 & 57.5 & 60.4 & 55.0 & 60.4 & 60.4 & 60.4 & 31.4 & 31.4 & 31.4 & 31.4 \\
\hline Deposits & 27.9 & 15.2 & 13.1 & 20.4 & 32.0 & 21.4 & 32.0 & 41.3 & 41.1 & 31.8 & 36.3 & 31.8 & 31.8 & 31.8 & 31.8 & 31.8 & 31.8 & 31.8 \\
\hline Public enterprises & 2.4 & 1.7 & 1.6 & 2.3 & 1.9 & 2.0 & 3.0 & 2.8 & 2.9 & 3.0 & 3.0 & 3.0 & 3.0 & 3.0 & 3.0 & 3.0 & 3.0 & 3.0 \\
\hline Private sector & 158.7 & 191.3 & 335.0 & 333.8 & 322.1 & 318.1 & 352.0 & 358.2 & 363.9 & 341.4 & 377.1 & 388.4 & 423.9 & 442.0 & 464.5 & 476.4 & 558.8 & 656.4 \\
\hline Other items (net; asset +) & -53.1 & -64.1 & -96.0 & -95.5 & -95.9 & -102.0 & -92.0 & -103.0 & -96.9 & -87.0 & -97.1 & -102.5 & -117.3 & -110.2 & -92.3 & -92.4 & -102.5 & -102.5 \\
\hline Deposits & 230.2 & 305.3 & 382.9 & 362.7 & 359.8 & 393.0 & 444.0 & 431.8 & 470.8 & 475.5 & 506.6 & 510.4 & 538.3 & 540.6 & 571.6 & 579.1 & 637.3 & 722.4 \\
\hline Private & 185.8 & 246.9 & 326.0 & 310.6 & 310.2 & 333.4 & 383.2 & 368.8 & 400.3 & 415.9 & 438.0 & 450.8 & 478.3 & 480.6 & 511.6 & 519.1 & 577.3 & 662.4 \\
\hline Public (nongovernment) & 44.4 & 58.4 & 56.9 & 52.1 & 49.6 & 59.6 & 60.8 & 63.0 & 70.5 & 59.6 & 68.6 & 59.6 & 60.0 & 60.0 & 60.0 & 60.0 & 60.0 & 60.0 \\
\hline
\end{tabular}

CInternational Monetary Fund. Not for Redistribution 
Table 5. Rwanda: Monetary Survey, 2006-13 (concluded)

\begin{tabular}{|c|c|c|c|c|c|c|c|c|c|c|c|c|c|c|c|c|c|c|}
\hline & \multirow[t]{3}{*}{2006} & \multirow[t]{3}{*}{2007} & \multirow[t]{3}{*}{2008} & \multicolumn{4}{|c|}{2009} & \multicolumn{5}{|c|}{2010} & \multicolumn{4}{|c|}{2011} & \multirow{3}{*}{$\begin{array}{r}2012 \\
\text { Dec } \\
\text { Proj. } \\
\end{array}$} & \multirow{3}{*}{$\begin{array}{r}2013 \\
\text { Dec } \\
\text { Proi }\end{array}$} \\
\hline & & & & March & June & Sept & $\mathrm{Dec}$ & March & June & June & Sept & Dec. & March & June & Sept & Dec & & \\
\hline & & & & & & & Est & Est. & Est & Prog. $^{7}$ & Prog. & Prog. & Prog & Prog & Prog & Prog. & & \\
\hline \multicolumn{19}{|c|}{ (Billions of Rwanda francs) } \\
\hline Net Foreign Assets $^{2}$ & 285.1 & 351.5 & 403.8 & 348.7 & 389.5 & 424.0 & 441.8 & 407.8 & 474.5 & 453.0 & 484.8 & 447.6 & 448.1 & 408.1 & 434.9 & 467.2 & 461.6 & 463.0 \\
\hline Net domestic assets & 1.9 & 23.8 & 62.3 & 83.2 & 45.5 & 41.4 & 85.3 & 96.6 & 82.1 & 112.9 & 103.4 & 147.5 & 179.1 & 226.2 & 231.5 & 210.0 & 310.4 & 411.7 \\
\hline Domestic credit & 88.7 & 123.2 & 199.3 & 220.8 & 189.2 & 182.5 & 217.1 & 246.8 & 243.0 & 230.1 & 244.3 & 302.3 & 350.7 & 390.7 & 378.1 & 356.7 & 439.1 & 536.7 \\
\hline Government (net) & -73.9 & -73.4 & -142.3 & -119.5 & -139.3 & -140.8 & -141.3 & -119.9 & -126.8 & -120.4 & -139.0 & -96.2 & -84.3 & -62.4 & -97.5 & -130.8 & -130.8 & -130.8 \\
\hline Public nongovernment deposits (-) & -2.0 & -1.3 & -0.5 & -0.4 & -0.6 & -1.9 & -1.9 & -1.9 & -4.3 & -1.9 & -4.3 & -1.9 & -1.9 & -1.9 & -1.9 & -1.9 & -1.9 & -1.9 \\
\hline Public enterprises & 2.4 & 1.8 & 1.6 & 2.3 & 1.9 & 2.0 & 3.0 & 2.8 & 2.9 & 3.0 & 3.0 & 3.0 & 3.0 & 3.0 & 3.0 & 3.0 & 3.0 & 3.0 \\
\hline Private sector & 162.2 & 196.2 & 340.5 & 339.4 & 329.3 & 325.3 & 359.9 & 365.9 & 371.2 & 349.4 & 384.6 & 397.4 & 433.9 & 452.0 & 474.5 & 486.4 & 568.8 & 666.4 \\
\hline Other items (net; asset +) & -86.8 & -99.4 & -137.0 & -137.6 & -143.8 & -141.2 & -132.2 & -150.2 & -160.8 & -117.2 & -140.9 & -154.8 & -171.6 & -164.5 & -146.6 & -146.7 & -156.8 & -156.8 \\
\hline Broad money ${ }^{5}$ & 287.0 & 375.2 & 466.1 & 432.9 & 436.8 & 467.5 & 527.1 & 504.4 & 556.5 & 565.9 & 590.0 & 595.1 & 627.2 & 634.3 & 666.5 & 677.2 & 772.0 & 874.7 \\
\hline Currency in circulation & 54.6 & 67.3 & 80.9 & 66.3 & 72.1 & 69.4 & 77.0 & 68.4 & 83.5 & 85.3 & 81.8 & 84.0 & 87.0 & 90.2 & 93.0 & 96.2 & 132.8 & 150.5 \\
\hline Deposits & 232.3 & 307.9 & 385.2 & 366.6 & 364.7 & 398.0 & 450.1 & 436.0 & 473.1 & 480.6 & 508.2 & 511.1 & 540.2 & 544.1 & 573.5 & 581.0 & 639.2 & 724.3 \\
\hline Of which: foreign currency deposits & 52.5 & 62.7 & 74.7 & 71.7 & 72.7 & 78.9 & -83.5 & - & - & 85.4 & 85.4 & 93.3 & - & 1.0 & 2.0 & 104.3 & 112.9 & 125.7 \\
\hline \multicolumn{19}{|c|}{ (Annual changes in percent of beginning-of-period broad money) } \\
\hline Net foreign assets & 28.7 & 23.1 & 13.9 & -5.1 & -4.2 & 7.6 & 9.7 & -6.5 & 6.2 & 24.1 & 21.8 & 1.1 & 1.2 & 14.0 & 11.1 & 5.9 & -0.8 & 0.2 \\
\hline Net domestic assets & 2.6 & 7.6 & 10.3 & 23.8 & 21.3 & 9.0 & 23.4 & 2.1 & -0.6 & 6.9 & 13.3 & 11.8 & 17.8 & 34.9 & 40.5 & 10.5 & 14.8 & 13.1 \\
\hline Domestic credit & 8.2 & 12.0 & 20.5 & 32.2 & 32.0 & 18.1 & 28.4 & 5.6 & 4.9 & 2.1 & 12.6 & 16.2 & 25.4 & 40.9 & 39.0 & 9.1 & 12.2 & 12.6 \\
\hline Government (net) & -5.6 & 0.2 & -18.1 & -5.1 & 2.0 & -3.5 & 0.4 & 4.1 & 2.7 & -0.2 & 0.1 & 8.6 & 10.8 & 14.5 & 8.6 & -6.7 & -- & -- \\
\hline Economy & 13.8 & 11.9 & 38.6 & 37.5 & 30.6 & 22.1 & 28.7 & 1.1 & 1.7 & 2.1 & 12.1 & 7.1 & 14.0 & 26.4 & 30.4 & 14.9 & 12.2 & 12.6 \\
\hline Other items (net; asset + ) & -5.6 & -4.4 & -10.2 & -8.3 & -10.8 & -9.1 & -5.0 & -3.4 & -5.4 & 4.7 & 0.7 & -4.3 & -7.5 & -6.0 & 1.5 & 1.4 & -1.5 & - \\
\hline Broad money & 31.3 & 30.8 & 24.2 & 19.0 & 17.6 & 17.1 & 33.2 & -4.3 & 5.6 & 30.7 & 35.1 & 12.9 & 19.0 & 48.7 & 51.8 & 13.8 & 14.0 & 13.3 \\
\hline \multicolumn{19}{|c|}{ (Annual percent changes) } \\
\hline Net foreign assets & 28.2 & 23.3 & 14.9 & -13.9 & -1.0 & 5.1 & 9.4 & 16.9 & 21.8 & 29.9 & 24.5 & 1.3 & 1.4 & 17.1 & 12.6 & 4.4 & -1.2 & 0.3 \\
\hline Net domestic assets & -150.0 & 1,164 & 162.1 & -347.6 & 726.2 & -655.6 & 36.9 & 16.1 & 80.6 & 35.7 & 127.4 & 72.9 & 110.0 & 192.5 & 330.2 & 42.3 & 47.8 & 32.6 \\
\hline Domestic credit & 25.2 & 38.9 & 62.8 & 214.5 & 71.4 & 74.1 & 8.9 & 11.8 & 28.4 & 4.2 & 29.1 & 39.3 & 61.6 & 80.8 & 82.8 & 18.0 & 23.1 & 22.2 \\
\hline Government (net) & 20.0 & -0.7 & 91.7 & -18.6 & 9.7 & -1.4 & -0.7 & 0.4 & -8.9 & 0.8 & -0.2 & -31.9 & -40.3 & -49.8 & -28.0 & 36.0 & - & - \\
\hline Economy & 22.8 & 20.9 & 73.7 & -13.7 & -15.6 & -16.8 & 18.5 & 53.1 & 77.4 & 2.7 & 15.9 & 10.4 & 20.5 & 33.1 & 39.0 & 22.3 & 16.9 & 17.1 \\
\hline Credit to the Private Sector & 23.7 & 21.0 & 73.6 & 66.7 & 52.4 & 37.7 & 5.7 & 7.8 & 12.7 & 6.1 & 18.2 & 10.4 & 17.5 & 29.4 & 23.4 & 22.4 & 16.9 & 17.1 \\
\hline Other items (net; asset + ) & 16.3 & 14.5 & 38.9 & -17.0 & 1.1 & -6.3 & 5.6 & 18.1 & 15.4 & -14.9 & -2.0 & 17.1 & 29.8 & 18.5 & -4.2 & -5.2 & 6.9 & - \\
\hline \multicolumn{19}{|c|}{ (In percent, unless otherwise indicated) } \\
\hline Memorandum items: & & & & & & & & & & & & & & & & & & \\
\hline Currency/broad money ratio & 19.0 & 17.9 & 17.4 & 15.3 & 16.5 & 14.9 & 14.6 & 13.6 & 15.0 & 15.1 & 13.9 & 14.1 & 13.9 & 14.2 & 14.0 & 14.2 & 17.2 & 17.2 \\
\hline Reserve money annual growth & 11.9 & 30.7 & 23.5 & 3.3 & -2.5 & -0.8 & 0.3 & 4.0 & 8.4 & 6.1 & 14.6 & 11.7 & 14.9 & 24.3 & 31.0 & 13.9 & 14.0 & 13.3 \\
\hline Broad money annual growth & 31.3 & 30.8 & 24.2 & 19.0 & 17.6 & 17.1 & 13.1 & 16.5 & 27.4 & 29.6 & 12.9 & 12.9 & 20.8 & 12.1 & 13.0 & 13.8 & 14.0 & 13.3 \\
\hline Reserves/deposits & 31.2 & 30.8 & 30.3 & 31.3 & 30.5 & 29.3 & 26.2 & 27.0 & 25.3 & 25.4 & 24.8 & 25.5 & 24.8 & 25.8 & 25.1 & 25.6 & 26.5 & 26.5 \\
\hline Money multiplier & 4.0 & 4.0 & 4.0 & 3.8 & 4.0 & 4.1 & 4.5 & 4.3 & 4.7 & 4.7 & 4.7 & 4.6 & 4.7 & 4.6 & 4.6 & 4.6 & 4.6 & 4.6 \\
\hline $\begin{array}{l}\text { Velocity of broad money (end of period) } \\
\text { Velocity of broad money (average of period) }\end{array}$ & $\begin{array}{l}6.0 \\
6.8\end{array}$ & $\begin{array}{l}5.5 \\
6.2\end{array}$ & $\begin{array}{l}5.5 \\
5.5\end{array}$ & $\begin{array}{l}6.8 \\
7.4\end{array}$ & $\begin{array}{l}6.8 \\
7.1\end{array}$ & $\begin{array}{l}6.3 \\
6.9\end{array}$ & $\begin{array}{l}5.6 \\
6.0\end{array}$ & $\begin{array}{l}6.5 \\
6.4\end{array}$ & $\begin{array}{l}5.9 \\
6.1\end{array}$ & $\begin{array}{l}5.8 \\
6.6\end{array}$ & $\begin{array}{l}5.6 \\
6.4\end{array}$ & $\begin{array}{l}5.5 \\
7.3\end{array}$ & $\begin{array}{l}5.9 \\
6.4\end{array}$ & $\begin{array}{l}5.8 \\
6.9\end{array}$ & $\begin{array}{l}5.5 \\
6.6\end{array}$ & $\begin{array}{l}5.4 \\
5.4\end{array}$ & $\begin{array}{l}5.4 \\
5.4\end{array}$ & $\begin{array}{l}5.3 \\
5.3\end{array}$ \\
\hline Net open position of the NBR (RF billion) & 219.1 & 275.6 & 317.9 & 266.8 & 306.6 & 337.8 & 351.3 & 322.6 & 396.4 & 365.1 & 386.2 & 348.4 & 349.1 & 314.7 & 342.8 & 365.6 & 359.9 & 361.3 \\
\hline Net open position of commercial banks (RF billion) & 13.5 & 13.2 & 11.2 & 10.2 & 10.2 & 7.3 & 6.8 & 85.1 & 78.1 & - & - & - & -- & - & - & - & - & -- \\
\hline Extended broad money (RF billion) ${ }^{6}$ & 333.8 & 438.2 & 473.7 & 371.9 & 369.4 & 407.1 & 493.1 & 402.6 & 538.1 & 525.6 & 547.9 & 552.7 & 582.5 & 589.1 & 619.0 & 717.0 & 255.0 & 256.0 \\
\hline Nominal GDP (RF billion) & $1,716.3$ & $2,049.3$ & $2,565.3$ & $2,964.0$ & $2,964.0$ & $2,964.0$ & $2,964.0$ & $3,278.3$ & $3,278.3$ & $3,278.3$ & $3,278.3$ & $3,278.3$ & $3,671.7$ & $3,671.7$ & $3,671.7$ & $3,671.7$ & $4,130.6$ & $4,638.7$ \\
\hline \multicolumn{19}{|c|}{ Source: National Bank of Rwanda (NBR) and IMF staff estimates and projections. } \\
\hline \multicolumn{19}{|c|}{$\begin{array}{l}1 \text { Reflects the operations of the Union Banques Populaires du Rwanda (UBPR)-a la } \\
{ }^{2} \text { For program purposes NFA from } 2010 \text { onwards are at program exchange rates. }\end{array}$} \\
\hline \multicolumn{19}{|c|}{${ }^{3}$ The IMF's MDRI reduced foreign liabilities at the NBR by RF 42.4 million with a counter entry in government deposits (in January 2006). } \\
\hline${ }^{4}$ Reserve money as an Assessment Criteria is meas & & & & & & & & & ed & $x$ & of & throe & bs. & guart & & & & \\
\hline${ }^{5}$ End-2006 broad money includes RF5 billion tempo & Lild & 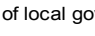 & 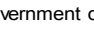 & sits & & & ebr & 007. & & & & & & & & & & \\
\hline $\begin{array}{l}{ }^{6} \text { Broad money plus deposits in the Union de Banqu } \\
{ }^{7} \text { IMF Country Report No. } 10 / 200 .\end{array}$ & & & & & & & & & & & & & & & & & & \\
\hline
\end{tabular}

CInternational Monetary Fund. Not for Redistribution 
Table 6. Rwanda: Financial Soundness Indicators for Banking Sector, 2006-2010 (in percent)

\begin{tabular}{|c|c|c|c|c|c|c|c|c|c|c|c|c|}
\hline & $\begin{array}{c}2006 \\
\mathrm{Dec}\end{array}$ & $\begin{array}{l}2007 \\
\text { Dec } \\
\end{array}$ & $\begin{array}{c}2008 \\
\text { Mar }\end{array}$ & $\begin{array}{l}2008 \\
\text { June }\end{array}$ & $\begin{array}{l}2008 \\
\text { Dec }\end{array}$ & $\begin{array}{c}2009 \\
\text { Mar }\end{array}$ & $\begin{array}{l}2009 \\
\text { June }\end{array}$ & $\begin{array}{c}2009 \\
\text { Sep }\end{array}$ & $\begin{array}{c}2009 \\
\text { Dec }\end{array}$ & $\begin{array}{c}2010 \\
\text { Mar }\end{array}$ & $\begin{array}{l}2010 \\
\text { June }\end{array}$ & $\begin{array}{c}2010 \\
\text { Sep }\end{array}$ \\
\hline \multicolumn{13}{|l|}{ Capital adequacy } \\
\hline Solvency ratio & 13.7 & 16.6 & 15.1 & 18.0 & 15.9 & 19.1 & 19.3 & 20.5 & 19.0 & 18.1 & 17.6 & 20.3 \\
\hline Off balance sheet items/Total qualifying capital & 334.8 & 305.6 & 221.7 & 205.9 & 210.2 & 182.5 & 160.7 & 164.0 & 184.1 & 197.6 & 224.4 & 202.9 \\
\hline Insider loans/Core capital & 45.2 & 57.9 & 20.1 & 9.3 & 16.7 & 9.2 & 17.0 & 7.3 & 19.7 & 15.7 & 13.5 & 10.2 \\
\hline Large exposure/core capital & 131.6 & 127.7 & 77.9 & 67.5 & 103.1 & 92.7 & 82.8 & 72.9 & 65.1 & 93.9 & 103.0 & 79.9 \\
\hline \multicolumn{13}{|l|}{ Asset quality } \\
\hline NPLs / Gross Loans & 25.0 & 18.1 & 12.2 & 12.0 & 12.6 & 13.8 & 13.4 & 13.6 & 13.1 & 12.5 & 12.2 & 12.4 \\
\hline NPLS net/Gross loans & 12.5 & 14.3 & 9.6 & 8.0 & 10.5 & 11.0 & 11.1 & 11.7 & 11.4 & 11.0 & 10.4 & 10.7 \\
\hline Provisions / NPLs & 83.5 & 67.0 & 78.1 & 75.5 & 66.3 & 67.6 & 70.9 & 65.9 & 55.2 & 57.2 & 56.8 & 56.4 \\
\hline Earning Assets / Total Asset & 85.3 & 59.6 & 80.1 & 80.9 & 81.3 & 78.4 & 77.3 & 77.1 & 81.7 & 78.2 & 81.1 & 77.6 \\
\hline Large Exposures / Gross Loans & 20.2 & 21.2 & 12.6 & 13.0 & 17.4 & 18.4 & 17.5 & 16.9 & 13.9 & 18.5 & 20.4 & 17.4 \\
\hline \multicolumn{13}{|l|}{ Profitability and earnings } \\
\hline Return on Average Assets & 2.4 & 1.5 & 4.9 & 2.7 & 2.4 & 1.6 & 0.9 & 1.0 & 0.7 & -0.2 & 1.3 & 2.5 \\
\hline Return on Average Equity & 27.0 & 15.5 & 10.8 & 21.9 & 18.5 & 11.4 & 6.4 & 7.0 & 5.0 & -1.4 & 10.3 & 18.7 \\
\hline Net Interest Margin & 8.0 & 5.2 & 10.1 & 8.9 & 9.5 & 10.3 & 10.2 & 9.9 & 9.1 & 9.6 & 8.8 & 13.3 \\
\hline Cost of Deposits & 2.6 & 2.6 & 1.8 & 1.9 & 1.8 & 1.7 & 2.1 & 2.3 & 2.4 & 2.8 & 2.7 & 3.9 \\
\hline Cost to Income & 76.7 & 80.2 & 64.1 & 74.1 & 77.5 & 83.7 & 89.8 & 89.8 & 91.0 & 98.6 & 89.3 & 85.9 \\
\hline Overhead to income & 46.2 & 44.2 & 41.6 & 46.7 & 48.6 & 52.2 & 53.4 & 55.5 & 54.9 & 57.5 & 54.0 & 54.2 \\
\hline \multicolumn{13}{|l|}{ Liquidity } \\
\hline Short term Gap & 34.2 & 21.5 & 13.6 & 25.5 & 21.3 & 17.2 & 20.1 & 20.1 & 20.0 & 16.8 & 21.2 & 17.4 \\
\hline Liquid Assets / Total Deposits & 64.7 & 76.4 & 54.0 & 60.4 & 61.1 & 65.4 & 59.3 & 61.7 & 65.3 & 51.7 & 58.4 & 47.9 \\
\hline Interbank Borrowings / Total Deposits & 11.3 & 10.3 & 6.6 & 5.7 & 8.1 & 9.3 & 9.1 & 8.2 & 9.8 & 7.3 & 10.3 & 9.0 \\
\hline BNR Borrowings / Total Deposits & 0.3 & 0.2 & 0.2 & 0.1 & 0.2 & 0.1 & 0.1 & 0.4 & 0.8 & 0.8 & 0.0 & 0.0 \\
\hline Gross loans/Total deposits & 71.1 & 63.3 & 81.0 & 76.2 & 87.8 & 88.6 & 82.8 & 76.1 & 73.9 & 74.0 & 71.6 & 69.2 \\
\hline \multicolumn{13}{|l|}{ Market sensitivity } \\
\hline Forex Exposure / Core Capital' & 9.0 & 8.7 & 2.6 & -5.2 & -4.6 & 0.6 & 5.9 & 0.8 & 1.9 & 4.9 & 1.5 & 2.4 \\
\hline Forex Loans / Forex Deposits & 0.8 & 1.0 & 1.2 & 0.5 & 0.5 & 0.4 & 0.6 & 0.5 & 2.8 & 2.6 & 4.2 & 2.1 \\
\hline Forex Assets / Forex Liabilities & 104.4 & 112.0 & 115.6 & 105.5 & 102.6 & 93.5 & 107.7 & 102.8 & 103.6 & 105.8 & 101.0 & 103.9 \\
\hline
\end{tabular}

Source: National Bank of Rw anda

${ }^{1}$ Data from 2007 and 2008 have been revised. 


\section{APPENDIX I \\ LETTER OF INTENT}

Kigali, Rwanda

December 4, 2010

Mr. Dominique Strauss-Kahn

Managing Director

International Monetary Fund

$70019^{\text {th }}$ Street, N.W.'

Washington, D.C., 20431

\section{Dear Mr. Strauss-Kahn,}

1. The attached Memorandum on Economic and Financial Policies (MEFP) reviews recent economic developments in Rwanda and implementation of Rwanda's economic program under the three-year Policy Support Instrument (PSI), which was approved by the IMF Executive Board on June 17, 2010. The attached MEFP is an update of the previous MEFP and sets out policies and programs the Rwandan government intends to implement for the rest of the fiscal year 2010/11. The PSI will expire on June 29, 2013.

2. All quantitative assessment criteria and structural benchmarks under the PSI program for end-June 2010 were met. The indicative target on domestic debt of the public sector was missed at end-June, as the government had to issue Treasury bills to ease its tight cash flow due to late donor disbursements. The debt is expected to be repaid soon as donor funds have already been disbursed.

3. Structural reforms are broadly on track. Notably, public financial management has continued to improve with the rollout of core modules of Integrated Financial Management Information System (IFMIS/Smartgov) to 94 agencies, while revenue administration has been strengthened with the Rwanda Revenue Authority taking over the collection and audit functions of social security contributions. The National Bank of Rwanda (NBR) has enhanced the effectiveness of monetary policy, in particular by holding frequent meetings of the Monetary Policy Committee (MPC), backed by an improved communication strategy. Also at the NBR, an exchange rate corridor framework was introduced as a transition measure toward greater exchange rate flexibility. All structural benchmarks for July-September were met except for the submission of an export diversification strategy to Cabinet. Although the draft export strategy was available by the August benchmark date, it will be submitted to Cabinet by end-January 2011, pending incorporation of comments from stakeholder discussions. The government is on track to meet most of the end-December 2010 structural benchmarks. The submission to Cabinet of the medium-term debt strategy is now planned for end-January reflecting delays in hiring consultants to assist with the strategy. 
4. In light of the satisfactory program implementation and performance and additional reforms and policies outlined in the attached MEFP, the government requests completion of the first review of the PSI.

5. The Government is requesting modifications to the Assessment Criteria for end December 2010 approved under the original PSI in June 2010 (IMF Country Report No. 10/200) to take into account delays in donor budget support disbursements, observed seasonalities in currency in circulation, and the exclusion of the central bank's monetary policy instruments from the domestic debt definition as this could prevent an effective mopping up of excess liquidity to achieve our inflation objective. The proposed changes are therefore as follows: (i) modifications to the adjusters on net foreign assets (NFA) of the central bank and net domestic financing (NDF) to keep pace with the size of delays in donor grants which have grown over time; (ii) modifications to the definition of reserve money targets to better align to seasonalities in currency in circulation; (iii) modifications to consolidated domestic debt limit to exclude debt issued by the central bank for monetary policy purposes in order to allow it to effectively mop up excess liquidity and achieve its inflation objective; and (iv) modifications to exclude one stateowned bank (Banque de Kigali (BK)) that poses little fiscal risk from the debt limit under the PSI to allow the bank to borrow on non-concessional terms with long maturities for on-lending to small- and-medium size firms, and address balance sheet maturity mismatches. The details of the modifications are in the attached TMU.

6. The Government requested that a second bank, Banque Rwandaise de Développement (BRD) also be excluded from the debt limit under the PSI. Fund staff after assessing the bank decided that the Bank currently cannot be excluded from the debt limit mainly because it currently poses some fiscal risk as well as the absence of a sufficiently independent Board. The Government however is of the view that BRD should qualify for exclusion as explained in the attached MEFP. The Government's position is strengthened by the fact that BRD has remained operationally independent from Government and has operated for several years without recourse to government guarantee. It also has a good past record in managing external credit lines.

It does not therefore pose any fiscal risk on the Government's budget. It is on these grounds that we request that the Fund reconsider the exclusion of BRD in the forthcoming PSI review.

7. The Government believes that the policies and measures set forth in the attached Memorandum are adequate to achieve the objectives of the PSI-supported program for the remaining months of the fiscal year. The Government remains committed to these objectives, and will take prompt actions and additional measures necessary for their achievement. The Government will consult with the IMF - at its own initiative or whenever the Managing Director of the IMF requests such a consultation-before the adoption of any such measures or changes to the policies described in the attached Memorandum.

8. The Government will provide the Fund with such information as the Fund may request in connection with the progress made in implementing the economic and financial policies and 
achieving the objectives of the program. It is expected that the second review will take place before end-June 2011, and the third review will also take place before end-December 2011.

9. The Government of Rwanda authorizes the publication and distribution of this letter, its attachments, and all reports prepared by the Fund staff, which also includes the Article IV consultation report.

Sincerely yours,

$$
/ \mathrm{s} /
$$

$$
\text { /s/ }
$$

John Rwangombwa

Minister of Finance and Economic Planning
François Kanimba

Governor, National Bank of Rwanda 


\section{Attachment I. Rwanda: Memorandum of Economic and Financial Policies}

\section{December 4, 2010}

\section{UPDATE}

1. In this updated Memorandum of Economic and Financial Policies (MEFP), the Government of Rwanda remains committed to achieving sustained economic growth and poverty reduction. The strategies to achieve these goals are set out in the Economic Development and Poverty Reduction Strategy (EDPRS) for 2008-12 ${ }^{1}$ and Rwanda's Vision 2020. To this end, the Government and the International Monetary Fund (IMF) are cooperating on a three-year Policy Support Instrument (PSI) to support macroeconomic policies and structural reforms that underlie strategies in the EDPRS.

2. This MEFP reviews performance during 2009/10 and the first quarter of the fiscal year 2010/11 and describes policies and targets for remainder of 2010/11 and the medium term.

\section{Performance under the PSI}

3. At end June 2010, all quantitative assessment criteria have been met (Table 1). In the case of the indicative targets, all but one target was met. The ceiling on the stock of consolidated domestic debt of the public sector was missed due to delays in disbursement of budgetary grants (World Bank) and the necessity to sell more debt instruments to finance priority expenditures. The debt is expected to be repaid soon as donor funds have already been disbursed. All structural benchmarks were met for end-June (Table 2). Structural benchmarks for July-September have also been met except for the submission of an export diversification strategy to Cabinet. Although the draft export strategy was available by the August benchmark date, it will be submitted to Cabinet by end-January 2011 pending further review by stakeholders. The authorities are on track to meet the end-December 2010 structural benchmarks.

\section{Growth}

4. After a somewhat slower growth in 2009 reflecting the impact of the global financial crisis and the tight liquidity experienced in the country, a slight recovery has taken place in 2010. Real GDP growth is projected at 6.5 percent in 2010. Growth is led by agriculture especially food crops which continue to benefit from the large investments in fertilizer,

\footnotetext{
${ }^{1}$ Rwanda's latest EDPRS (IMF Country Report No. 08/90) and Joint Staff Advisory Note (IMF Country Report No. $\underline{08 / 91}$ ) were issued to the Executive Board on February 14, 2008. A progress report will be issued to the IMF Board before the second PSI review.
} 
improved seeds and extension services under our Crops Intensification Program. Growth in the industrial sector was led by manufacturing especially food processing, electricity, gas and water as well as construction. In the case of electricity, gas, and water, this sub sector continues to benefit from the ongoing investments by the Government. The recovery in construction was mainly due to the resumption of credit to this sub sector as well as completion of some public projects. The recovery in the services sector reflects the ongoing improvements in financial services - finance and insurance-and the on-going investments in communication as well as the recovery in tourism and trade.

\section{Inflation}

5. Driven by sustained good performance in domestic food production, decline in import prices, stable exchange rate and limited growth of money supply, inflation has been maintained at low levels in 2010 compared to the last two years. Furthermore, improvement in fiscal and monetary policy management and coordination have continued to limit inflationary pressures. Overall inflation dropped from 5.7 percent in December 2009 to 1.5 percent in September 2010, and is expected to be below 5 percent at end-2010, well below the target of 7 percent projected for the year.

\section{Fiscal Performance}

6. Fiscal performance during FY2009/10 was on track as the net domestic finance target was met. The $2009 / 10$ overall fiscal deficit (including grants) was smaller than expected by 2.8 percent of GDP on account of higher revenues and lower spending. Domestic revenue collections exceeded projections by about 0.7 percent of GDP on account of "one off "collections of new motor vehicle registration tax at the beginning of the year. On the expenditure side, total spending was slightly lower by about 2.2 percent of GDP due to lower spending on foreign financed capital projects. This occurred because of delays in external loan disbursements. Consistent with EDPRS objectives, the priority spending target was also met. External grants were in line with the budget for 2009/10.

7. However, based on preliminary data for the first quarter of 2010/11 (July-September) trade taxes and non-tax revenues fell short of projections in the PSI program, owing mainly to a much larger-than-expected shift in imports from the EAC and COMESA and corresponding reduced import duties and other applicable taxes, a trend which had already started in January-June 2010. Lower revenues and grants contributed to a build-up of arrears, despite lower-than-programmed spending.

8. Also during the first quarter of 2010/11, delays occurred in the disbursement of external budget support grants by the World Bank. The short term financing gap was financed with the issuance of short term debt to the commercial banks. As a result the stock of domestic debt target at end June 2010 was slightly exceeded. 


\section{EDPRS implementation}

9. The financial year $2009 / 2010$ is the third financial year of implementing the EDPRS. By end-2009, out of 383 policy actions that were assessed, 374 had been implemented; an implementation rate of more than 97 percent. Many targets were exceeded and subsequently revised upwards for future financial years. Notably, progress has been made to improve infrastructure: 53.8 percent of national roads are now in good condition from a baseline of 11 percent in 2006; over the same period, electricity generation capacity has increased from $45 \mathrm{MW}$ to $84 \mathrm{MW}$ allowing an increase of 75 percent in the number of connections. Rwanda is now on track to achieve health and education-related MDGs, including increasing the coverage and the quality of basic and tertiary education, and strengthening technical and vocational education and training. It has already achieved MDGs related to gender equality and has also made good progress towards increasing access to water and sanitation for its population. In the area of governance, satisfactory progress has been made in strengthening PFM, justice, decentralization and citizen participation.

\section{External Sector}

10. The balance of payments is expected to end 2010 with a small deficit and reserves coverage would be 4.6 months of imports. The trade deficit would increase but by less than originally thought, as strong export performance is more than offset by additional imports. The export rebound in 2010 is due mainly on account of strong performance in the coffee and tea sectors, as their combined exports are expected to increase by about 40 percent compared to 2009. Non-traditional exports are also performing well and the results of the Informal Cross-Border Trade Survey, included for the first time in the export statistics, indicate a net surplus for informal net exports. Mineral exports would be nearly unchanged from 2009 as higher prices are offset by smaller export volumes. The tourism sector is rebounding from its decline in 2009 though not yet to the extent as was expected. Imports in 2010 would increase by about 20 percent compared to 2009 and be driven by higher imports of energy, intermediate, and consumer goods. Imports of capital goods would be up only slightly for the year and fall below expectations on account of slower-than-expected execution of a few large investment projects. Progress with regional integration has resulted in a shift of imports; data for January-June 2010 shows that the share of imports from EAC countries has increased to 32 percent when compared with 26 percent in the same period in 2009 and 25 percent in 2008. As public and private current transfers would increase in 2010 and partly offset the higher trade deficit, the current account deficit including grants would be about 7 percent of GDP in 2010 (against 7.9 percent of GDP programmed), which is slightly below the level in 2009 . On the financial side of the balance of payments, some plans to finance large projects are expected to be finalized by the end of the year and its foreign investment component (foreign direct investment and external borrowing) has been pushed back to 2011. The financial account is also supported by private external borrowing, including in the telecommunications to finance equipment and intermediate imports. 


\section{Monetary and Exchange rate Developments}

11. In response to the domestic liquidity crisis which started in 2008 , the NBR has maintained an accommodative monetary policy stance in the last 18 months to boost liquidity and support the expected turnaround in growth. The policy rate, which also serves as the key repo rate, has been cut cumulatively by 200 basis points since November 2009 . However, commercial banks have maintained a cautious credit stance while enhancing their risk management practices and loan recovery processes. As a result, growth in credit to private sector has been slower than expected, as it is forecasted to increase by about 10 percent by end 2010, well below the 20 percent growth initially projected.

12. The introduction of the exchange rate corridor framework in July 2010 as a transitional measure toward a market based exchange rate framework introduced more flexibility in the movement of the foreign exchange market. The Rwandan franc depreciated by 3 percent against the US dollar between April and August 2010, higher than the depreciation observed in the entire 2009.

\section{Financial sector}

13. After a challenging year, the banking system in 2010 began to show clear signs of recovery. In general, banks remain well capitalized, with strong solvency, liquidity and improving asset quality which have increased public confidence in the banking sector. The capital adequacy ratio of the banking system stood at 17.6 percent as of June 30, 2010, well above the regulatory capital of 10 percent for Tier 1 capital and 15 percent for total Capital. A slight upgrade in asset quality was observed through a decrease in nonperforming loans (NPL) from 13.1 percent in December 2009 to 12.2 percent at end June 2010. Bank profitability also increased. At end June, 2010 return on equity and return on assets increased respectively from 6.4 percent to 10.3 percent and from 0.9 percent to 1.3 percent compared to June 30, 2009 .

14. In 2010, 6 on-site inspections are planned to be conducted of which 4 have already been completed. In addition, 4 Banking Regulations were approved by September 2010, one of which is loan classification and provisioning. The legal framework to operate a private credit reference bureau has also been developed. The law on credit information system was passed by the Parliament in May 2010 and a new private credit bureau, CRB Africa, was licensed in May 2010 and launched in July 2010. Central Bank will oversee the operations of the duly licensed credit bureau and will continue to sensitize the public on the importance of the credit reference agencies and legal rights of consumers. The non-bank supervision department conducted an onsite inspection of Caisse Sociale du Rwanda (CSR) in October 2010.

15. The NBR also adopted a number of regulatory and institutional reforms to further strengthen the supervision of microfinance (MFIs) and non-bank financial institutions (NBFI's). Insurance regulations to implement the new insurance were finalized and published in the Official Gazette in September 2010 and the last two regulations were approved by the NBR's Board of Directors in September 2010 and will be published in the Official Gazette 
before end-December 2010. Regarding the MFIs, the NBR is implementing the new regulatory guidelines. In line with the MFIs, NBR intensified on-site inspections depending on the results of the off-site analysis and meetings with governing bodies of the MFIs with deteriorating asset quality.

16. The Functional Specifications (FS) for the Automated Transfer System (ATS) has been approved, hardware and software received and tested by BNR. The system for the backup site has also been accepted and tested at BNR headquarters, and moved to the interim Disaster Recovery site at Rwanda Development Board Information Technology (RDB IT) data centre. The first phase of Rwanda Integrated Payments Processing System (RIPPS) software has been received and customized to the Functional Specification agreed by BNR and full acceptance testing of software carried out. The complete system will be up and running on schedule by end June 2011.

17. The Electronic Transactions Law and the Central Securities Law were published in the official gazette in May 2010. On the other hand, the regulation on Electronic Funds transfers and Electronic money and the one governing payments and securities systems were passed by the BNR board and waiting to be published in the official gazette by end December 2010 . Lastly, Guidelines on cards operations and an oversight framework are being drafted.

\section{Statistical Issues}

18. Efforts to improve the quality of national accounts are continuing. In October 2010 , the NISR disseminated its quarterly GDP estimates for the first and second quarters of 2010, together with minor revisions of GDP estimates for 2008 and 2009. The NISR finalized the design of Living Standards Measurement Questionnaire (EICV) as committed by the endSeptember structural benchmark. The 2010 household survey incorporating the finalized questionnaire is to be conducted from November 2010 to October 2011. Progress has also been made revising the methodology for conducting ex-ante and ex-post agricultural crop assessments (to be finalized by end-Dec 2010). Starting with the 2011 season A crop, the NISR are already using the preliminary revised ex-ante survey and will follow up with the ex-post agricultural crop assessment starting with the season A crop.

\section{Objectives and Policies Looking Forward}

19. The outlook for the remainder of the fiscal year is in line with our Medium Term Macroeconomic Framework and program objectives set out in our initial MEFP. Our overriding objective is to sustain real GDP growth rates above 7 percent per year. Continued macroeconomic stability is a necessary condition for meeting this challenge. Inflation is targeted at 6 percent for end-2011 and stabilizing at 5 percent over the medium-term. 


\section{A. Fiscal Policy}

20. The budget for fiscal year $2010 / 2011$ has been revised for fiscal year 2010/11 to take account of lower revenues offset by expenditures cuts, leaving the overall fiscal balance (including grants) unchanged. The revised budget will be submitted to Parliament before end-2010. The original targeted increase in domestic revenue mobilization of about $1.4 \%$ of GDP (compared to 1.1 percent of GDP in the revised program) was based on a much faster recovery of the monetized sector of the economy and an accelerated increase in revenue yield from the implementation of the on-going administrative reforms. As a result of a slower recovery together with larger than projected revenue loss from trade with the EAC and COMESA region, and poor performance of profit taxes resulting from the financial crisis in 2009 , total collections are now expected to be lower by about Rwf 8.5 billion ( 0.2 percent of GDP). In order to compensate for the expected revenue shortfalls from trade taxes and corporate taxes in 2010/11, the authorities will take additional efforts to collect revenues in other areas, as well as continue to implement ongoing tax administration measures. Looking forward, the authorities intend to request an FAD mission from the IMF to review tax policy. The additional efforts for 2010/11 include:

- Increase the number of taxpayers by 10 percent from 42,538 (end June 2010) through end June 2011 as a result of collecting pension funds and using the Block Management System which will boost tax collections including Income and VAT taxes.

- Enforcement efforts shall be intensified to avoid aging of arrears and recover collectible ones amounting to Rwf 8 billion by June 2011 compared to Rwf 6.5 billion in the PSI program.

- Start using risk-based audit planning, targeting high risk sectors and gives them a priority to ensure that all large and half of the medium taxpayers sectors are current in audit by end 2011 .

21. Consistent with our policy of maintaining the net domestic finance at the same level as originally programmed, we will offset the expected revenue shortfall with an expected compensation from the EAC-Comesa Fund for revenue losses for 2009/10 (US\$ 14 million or about Rwf 8 billion). In case the compensation is not realized, the revised 2010/11 budget will include identified contingent expenditure cuts in non-priority areas amounting to 0.2 percent of GDP (see Table below). The use of the government's overdraft at NBR at the beginning of 2010 was considered one-off event related to delays in donor disbursements. We will continue to use this facility again for cash flow purposes in future if there are delays in donor disbursements. However we will give the retirement of such facility priority when the donor funds are received. 


\begin{tabular}{|l|l|c|c|c|}
\hline \multicolumn{5}{|c|}{$\begin{array}{r}\text { PROPOSED EXPENDITURE CUTS } \\
\text { 2010/11 BUDGET } \\
\text { (in billion Rfw) }\end{array}$} \\
\hline S/N & \multicolumn{1}{|c|}{ CATEGORY } & Approved Budget & $\begin{array}{c}\text { Amount to be } \\
\text { Cut }\end{array}$ & $\begin{array}{c}\text { Share of } \\
\text { GDP }\end{array}$ \\
\hline A & Goods and Services & 42.2 & 4.0 & 0.1 \\
\hline B & Transfers & 40.6 & 5.4 & 0.2 \\
\hline C & $\begin{array}{l}\text { Domestic Capital } \\
\text { Expenditure }\end{array}$ & 4.1 & 3.3 & 0.09 \\
\hline & GRAND TOTAL & 86.9 & 12.7 & 0.4 \\
\hline
\end{tabular}

22. For the remaining period of fiscal year 2010/2011, we expect some minor delays in the disbursement of official external budget support grants. We will finance the temporary shortfall in resources with short term debt instruments which will increase our domestic debt. The stock of domestic debt (excluding T-bills issued for monetary policy purposes) at end of fiscal year 2010/2011 is therefore expected to amount to Rwf 212.1 billion compared to Rwf 177.8 billion at end 2009 .

23. Our budget for the medium term will be guided by our medium term expenditure framework and our approach to prudent fiscal policy. Accordingly, we will aim to continue to reduce the domestic finance requirements so that the private sector can lead economic growth and poverty reduction. We expect to reach our objective of increasing revenue from 12.5 percent of GDP in 2009/10 to 14.3 percent of GDP by 2012/13, as estimated in the PSI program, an important tool not only in securing resources for our development but also in reducing our reliance on external budgetary grants.

24. Looking ahead, before granting tax exemptions in the context of the export development strategy and PPPs, the government will carefully assess fiscal risks and any new tax incentives will remain fully transparent in tax codes and investment codes. MINECOFIN will strengthen capacity to assess the revenue losses of tax exemptions, in preparation for eventual inclusion in annual budget documents. Also, the government will ensure that all fiscal risks of any proposed PPPs are assessed, at an early stage, by MINECOFIN before any decision is taken. The government is also committed to submit to Cabinet its medium-term debt strategy.

25. The government also intends to improve its communication strategy by preparing quarterly budget execution reports, and publishing these on its website, within 45 days from the end of each quarter (continuous structural benchmark). The budget execution reports will include the central government operation table and an analysis of fiscal outturns against annual fiscal objectives, with a view to eventually preparing bi-annual reports that also 
analyze fiscal developments vis-à-vis medium-term fiscal objectives. This will help to ensure transparency and accountability of public resources.

\section{Public Financial Management}

26. The PEFA assessment is near completion. The preliminary 2010 scores improved significantly from the 2007 assessment (No indicator slipped back, the "A" scores increased by more than 300 percent whilst the " $D$ " scores declined by 45 percent) underpinned by the existence of a clear and advanced legal framework particularly for budget preparation and legislative scrutiny of the budget and improved compliance and oversight across the entire public financial management cycle.

\section{B. External Sector Policies}

27. Consistent with our medium term growth objectives averaging more than 7 percent per annum, our external current account deficit (excluding grants) which is estimated at about 7 percent of GDP at end 2010 will be expected to widen in 2011 to about 9.5 percent of GDP before declining slightly in the medium term. Higher imports especially capital equipment for some of the ongoing strategic investment projects and other consumer goods from the EAC and COMESA region contribute to the higher imports figure in 2011. Total export receipts (in US dollar terms) in the medium term are projected to rise slower than originally projected in the PSI program on account of expected sluggish developments concerning world commodity prices especially coffee, tea and minerals.

28. As a result, the balance of payments is projected to close in the medium term years with small deficits which will be financed with some draw down of international reserves. As a result, we expect gross official reserves to remain on average at a safe minimum coverage of 4 to 5 months of imports.

29. In the area of debt management, we will explore all avenues for concessional financing. However given the large requirement of resources for the financing of our development agenda, some non concessional financing will be necessary. We have already agreed to a ceiling of US\$240 million of non concessional borrowing during the PSI period for RwandAir and the Kigali Conference Center (KCC).

30. Currently two state owned banks, Bank of Kigali (BK) and Banque Rwandaise de Developpement (BRD) are holding discussions with the African Development Bank (AfDB) and the Agence Francaise de Developpement (AFD) for non-concessional lines of credit amounting to about US\$55 million. These funds, when secured, would be used for on-lending to Small and Medium Enterprises (SMEs) and others for long-term financing as well as mitigating asset-liability maturity mismatch in the case of Bank of Kigali. In view of the fact that both banks are performing well and have strong independent management as well as good past record in managing external lines of credit, we request that they should be excluded from 
the DSA definition. We wish to reiterate our position that these banks do not pose any fiscal risk to the Central Government's budget.

\section{Monetary and Exchange Rate Policies}

31. To support the economic growth, the NBR will maintain the current accommodative monetary policy stance going forward, but would continue to reassess the stance regularly to ensure underlying inflationary pressures are well anchored. The NBR will also ensure that real interest rates are kept positive to stimulate domestic savings mobilization and support the financial deepening required for growth.

32. At the same time, the NBR is committed to keeping inflation low and stable over the medium term. Inflation is projected at 4.6 percent in 2010, far below the 7 percent projected at the beginning of the year. The NBR projects a slight pick-up in inflation in 2011 to about 6 percent, with the aim to return to 5 percent in 2012 and stabilize at that rate over the medium-term. However, the risks of higher inflation remain due to uncertainties related to exogenous shocks, including food and fuel prices. Broad money growth estimated at about 13 percent in 2010 is projected to grow further by about 13.8 percent in 2011 , supported by a strong recovery in growth in credit to the private sector by about 22.4 percent in 2011 , up from an estimated 11 percent in 2010.

33. NBR will continue to use appropriate mix of monetary policy instruments to manage the liquidity in the banking system including reserve money targeting and the sale of foreign exchange to banks to support the objective of maintaining inflation at low levels while at the same time supporting growth. In addition, the NBR, with the assistance of TA from the IMF, will further reform the foreign exchange rate market towards greater flexibility, and encourage further deepening and development of the foreign exchange interbank market. The NBR will also continue to closely monitor the behavior of the Rwf exchange rate vis-a- vis the currencies of the major trading partners to limit the volatility of the real effective exchange rate to ensure competitiveness and boost growth.

34. NBR will eliminate, by end January 2011 (structural benchmark), the Average Reference Rate (ARR) — currently used as the NBR customer rate and for official accounting purposes. Henceforth, NBR will operate with new buying and selling customer rates established as margins on either side of the previous days' closing market rate. The closing market rate is the rate of the last market transaction - either between banks (i.e. interbank rate), or between banks and the central bank (i.e. intervention rate) — of a given day. In the event of no market transactions on a given day, the latest available closing market rate will prevail. For official accounting purposes, NBR will use as the Official Rate, the mid-point of the NBR customer buying and selling spread.

35. NBR will strengthen its capacity in economic analysis (including with technical assistance from IMF MCM and by training experienced economists in key areas, including (i) modeling inflation for policy simulations to provide analytical support to the Monetary 
Policy Committee (MPC) decisions; (ii) to analyze and forecast developments in the balance of payments; and (iii) build analytical capacity to assess economic fundamentals to determine when to intervene and re-base the exchange rate corridor.

\section{Financial Sector Reforms}

36. The NBR will continue to promulgate laws to strengthen the regulation of the financial sector. The pension law is expected to come into effect by end-March 2011. The two companion laws, the new insurance contract law (approved by NBR Board in September 2010) and the mandatory insurance law (still in the drafting process) are also expected to be passed by the Parliament before end 2011. At the same time Parliament has on its agenda to pass the law that governs the organization of collective investment schemes (CIS) by end 2010. These laws are aimed at giving the necessary regulatory backing to the development of the domestic capital markets in Rwanda. In addition, there are two other CMA draft laws expected to be passed by the Parliament before end 2010.

37. The NBR has initiated the process of developing an action plan to revamp the general capacity of its staff, particularly its supervision department by reviewing the general compensation and professional development scheme. The NBR intends to submit to its Board, by end-March 2011, an action plan to improve NBR's compensation scheme and professional development in order to strengthen improve staff motivation and increase staff retention. In this regard, NBR is conducting a salary survey, which will be completed by end-March 2011 .

38. The Banking Supervision Department is implementing its supervision program for 2010 with the assistance of senior bank examiners from the EAC central banks. Additionally, it expects to get TA from IMF and World Bank over the period 2011-2012 to enhance capacity of inspectors. NBR has a 2010-2011 comprehensive training program funded by the AfDB to build capacity of bank examiners. The program includes attachments to more experienced central banks and in-country training workshops. The NBR will also continue to hold joint bank inspection exercises with senior inspectors from other EAC central banks. NBR is on track to achieve at least 6 on-site inspections in 2010 with NBR staff (structural benchmark for end-December 2010). This is in addition to continual off-site surveillance for all banks and regular meetings with commercial bank management consistent with the risk based supervision framework. It is believed that all these capacity building and staff motivation initiatives will enable NBR to achieve the PSI objective of being able to conduct on-site inspections for each bank at least once in every 24 month cycle. Furthermore, the Government of Rwanda has requested for an FSAP update planned for early 2011 to advice on the expansion of the financial inclusion while limiting its vulnerabilities. In addition, the FSDP will be revised taking into account recommendations from the FSAP mission.

39. The NBR is taking steps to increase financial inclusion through NBFIs, while limiting its vulnerabilities. The NBR is strengthening its capacity to supervise the recent rapid expansion of MFIs, including some 416 UMURENGA SACCOs, including using Risk Based 
Supervision (RBS) in some large MFIs by December 2011. This will encourage big viable MFIs to upgrade to legal status of Micro-Finance Bank, and encourage Banks to expand their branch network. We do expect that these initiatives will enable Rwanda to achieve the objective of reaching a goal of 30 percent for financial inclusion by 2012, up from 21 percent cited by the Finscope Rwanda 2008 survey.

\section{E. Statistics}

40. The NISR will continue to improve the quality of the national accounts, in accordance with the improvement action plan of the national accounts. Using the revised methodology for the ex-ante and ex-post agricultural crop assessments (structural benchmark, end-Dec 2010), the NISR will begin conducting an ex-post crop assessments starting with the 2011 agricultural A season (SB end January 2011). The NISR also intends to update the metadata for the GDDS, and submit it to the IMF for posting by the end of March 2011. The NISR will also devote resources to hire economists to ensure consistency of its national accounts statistics with macroeconomic developments. 
Table 1. Quantitative Assessment Criteria and Indicative Targets for 2010-11 ${ }^{1}$ (Billions of Rwandan francs, unless otherwise indicated)

\begin{tabular}{|c|c|c|c|c|c|c|c|c|}
\hline & \multicolumn{6}{|c|}{2010} & \multicolumn{2}{|c|}{2011} \\
\hline & \multicolumn{4}{|c|}{ June } & \multirow{2}{*}{$\begin{array}{r}\text { Sep } \\
\text { Prog }\end{array}$} & \multirow{2}{*}{$\frac{\text { Dec }}{\text { Prog }}$} & \multirow{2}{*}{$\begin{aligned} \text { March } \\
\text { Prog }\end{aligned}$} & \multirow{2}{*}{$\begin{array}{ll}\text { June } \\
\text { Prog }\end{array}$} \\
\hline Assessment Criteria ${ }^{2}$ & Prog & Adjusted Prog & Est & Status & & & & \\
\hline Net foreign assets of the NBR at program exchange rate (floor on stock) ${ }^{3,4}$ & 369.3 & 368.2 & 384.7 & met & 390.5 & 352.6 & 353.2 & 318.9 \\
\hline Reserve money (ceiling on stock) ${ }^{5}$ & 122.5 & 122.5 & 121.7 & met & 126.2 & 129.9 & 132.1 & 135.8 \\
\hline Net domestic financing (ceiling on flow) ${ }^{4,6}$ & -7.5 & -6.3 & -11.2 & met & -26.3 & 22.7 & 39.1 & 68.9 \\
\hline $\begin{array}{l}\text { New nonconcessional and government guaranteed external debt (US } \$ \text { Millions) } \\
\text { (ceiling on stock) } 7,8\end{array}$ & 240.0 & 240.0 & 0.0 & met & 240.0 & 240.0 & 240.0 & 240.0 \\
\hline External payment arrears (US\$ Millions) (ceiling on stock) ${ }^{8}$ & 0.0 & 0.0 & 0.0 & met & 0.0 & 0.0 & 0.0 & 0.0 \\
\hline Indicative Targets & & & & & & & & \\
\hline Domestic revenue collection (floor on flow) ${ }^{6}$ & 197.9 & 197.9 & 204.3 & met & 313.2 & 424.0 & 552.2 & 675.4 \\
\hline Net accumulation of domestic arrears (ceiling on flow) ${ }^{6}$ & -3.0 & -3.0 & -6.1 & met & 4.8 & -13.1 & -15.1 & -17.1 \\
\hline Consolidated domestic debt of public sector (ceiling on stock, eop) ${ }^{4,9}$ & 211.1 & 212.3 & 264.8 & not met & 178.4 & 219.0 & 206.1 & 212.1 \\
\hline Total priority spending (floor on flow) ${ }^{6}$ & 212.0 & 212.0 & 228.7 & met & 342.7 & 458.7 & 573.7 & 688.8 \\
\hline Memorandum items: & & & & & & & & \\
\hline General budget grants (US $\$$ Millions) ${ }^{6,10}$ & 218.2 & 218.2 & 216.1 & & 330.6 & 418.0 & 509.9 & 541.7 \\
\hline
\end{tabular}

Sources: Rwandan authorities and IMF staff estimates and projections.

${ }^{1}$ All items including adjusters are defined in the attached Technical Memorandum of Understanding (TMU).

${ }^{2}$ Test dates for assessment criteria are for end-June and end-December, otherwise indicative targets.

${ }^{3}$ At program exchange rate of RWF 571.24 per US dollar for 2010 and 2011.

${ }^{4}$ Subject to adjustors. See TMU for details.

${ }^{5}$ Targets are calculated as an arithmetic average of the stock of reserve money for the three months in the quarter. See TMU for details.

${ }^{6}$ Numbers are cumulative from December 31, 2009.

${ }^{7}$ Cumulative from end-June 2010. The ceiling applies to the duration of the three-year PSI and is tied to two projects as specified in the MEFP. It excludes the IFC SWAP agreement of US\$50 million as well as US\$13.1 million for purchase of two small airplanes both of which were contracted in 2009 and external borrowing

by the Bank of Kigali.

${ }^{8}$ This is a continuous assessment criterion.

${ }^{9}$ Excluding NBR's debt issued for monetary policy purposes, starting on September 2010. See TMU for details

${ }^{10}$ Excluding demobilization and AU peace keeping operations, HIPC grant and COMESA compensation grant. 
Table 2. Rwanda: Structural Benchmarks for 2010/11

\begin{tabular}{|c|c|c|c|}
\hline Policy Measure & Target Date & Macroeconomic rationale & Status \\
\hline \multicolumn{4}{|l|}{ PFM } \\
\hline $\begin{array}{l}\text { 1. Strengthen the MTEF by completing PERs for two more sectors (ICT and } \\
\text { transportation). }\end{array}$ & End March 2011 & To improve multi-year fiscal planning. & Progress to be reviewed \\
\hline $\begin{array}{l}\text { 2. Begin pilot of core modules of Smartgov (a component of IFMIS) in Ministries and } \\
\text { Agencies. }\end{array}$ & End July 2010 & $\begin{array}{l}\text { To help budget preparation, reporting and } \\
\text { execution. }\end{array}$ & Met \\
\hline 3. Submit to Cabinet for approval a revised public debt policy and MTDS. & End January 2011 & $\begin{array}{l}\text { To assess costs and benefits of scaled-up } \\
\text { nonconcessional financing and analyze fiscal } \\
\text { risks associated with PPPs. }\end{array}$ & $\begin{array}{l}\text { Changed to end January } 2011 \text { from end } \\
\text { December } 2010 \text { owing to delays in hiring a } \\
\text { consultant to further refine the draft strategy. }\end{array}$ \\
\hline $\begin{array}{l}\text { Fiscal Performance } \\
\text { 4. MINECOFIN to publish (and put on its website) quarterly reports of budget execution } \\
\text { against annual fiscal policy objectives, within } 45 \text { days of end of each quarter. Initially } \\
\text { the quarterly budget execution reports will exclude foreign-financed projects. }\end{array}$ & $\begin{array}{l}\text { Continuous, starting } \\
\text { mid-May } 2011\end{array}$ & $\begin{array}{l}\text { To improve communication of fiscal } \\
\text { performance to stakeholders. }\end{array}$ & \\
\hline \multicolumn{4}{|l|}{ Revenue Administration } \\
\hline $\begin{array}{l}\text { 5. Submit to Cabinet for approval draft legislation to transfer collection and audit } \\
\text { functions of social security contributions (pension and RAMA) to RRA. }\end{array}$ & End December 2010 & $\begin{array}{l}\text { To improve compliance and widen the tax } \\
\text { base. }\end{array}$ & \\
\hline $\begin{array}{l}\text { 6. Improve risk-based assessment of ASYCUDA++ by electronic submission of } \\
\text { supporting customs documents. }\end{array}$ & End June 2010 & $\begin{array}{l}\text { To modernize customs collection and properly } \\
\text { assess liabilities }\end{array}$ & Met \\
\hline $\begin{array}{l}\text { Financial Sector } \\
\text { 7. NBR to conduct minimum of } 6 \text { on-site bank inspections with NBR staff. }\end{array}$ & End December 2010 & $\begin{array}{l}\text { To keep up with both on and off site prudential } \\
\text { oversight of banks consistent with risk-based } \\
\text { supervision framework }\end{array}$ & Progress to be reviewed \\
\hline \multicolumn{4}{|l|}{ Monetary Policy } \\
\hline $\begin{array}{l}\text { 8. NBR to publish (and put on its website) the underlying economic assessments } \\
\text { supporting MPC decisions within one month after every quarterly MPC meeting. }\end{array}$ & $\begin{array}{l}\text { Start date - End June } \\
2010\end{array}$ & $\begin{array}{l}\text { To improve communication and shape } \\
\text { expectations of market and general public and } \\
\text { enhance effectiveness of the monetary policy } \\
\text { framework. }\end{array}$ & Met \\
\hline \multicolumn{4}{|l|}{ Exchange Rate } \\
\hline 9. Announce the introduction of interbank exchange rate corridor framework. & End June 2010 & $\begin{array}{l}\text { To improve foreign exchange market efficiency } \\
\text { and allow exchange rates to move in line with } \\
\text { fundamentals. }\end{array}$ & Met \\
\hline $\begin{array}{l}\text { 10. Remove NBR's Average Reference Rate (ARR) and establish new NBR customer } \\
\text { buying and selling exchange rates. }{ }^{2}\end{array}$ & End January 2011 & Unifying official and customer exchange rate. & \\
\hline \multicolumn{4}{|l|}{ Export sector } \\
\hline $\begin{array}{l}\text { 11. Submit to cabinet for approval the draft export diversification strategy and action } \\
\text { plan. }\end{array}$ & End August 2010 & To broaden the export base. & $\begin{array}{l}\text { not met; To be implemented by end January } \\
2011 \text { to allow more time to incorporate further } \\
\text { review by stakeholders. }\end{array}$ \\
\hline \multicolumn{4}{|l|}{ Statistics } \\
\hline 12. Finalize design of living standards measurement questionnaire (EICV). & End September 2010 & To improve measurement of GDP growth. & Met. \\
\hline $\begin{array}{l}\text { 13. Revise methodology for conducting ex-ante and ex-post agricultural crop } \\
\text { assessment. }\end{array}$ & End December 2010 & To improve measurement of GDP growth. & Progress to be reviewed \\
\hline 14. Conduct ex-post crop assessment of 2011 season A. ${ }^{2}$ & End January 2011 & To improve measurement of GDP growth. & \\
\hline
\end{tabular}

1. Source: MEFP (June 2010, December 2010 Update) and staff assessment. 


\section{Attachment II. Technical Memorandum of Understanding December 4, 2010}

1. This memorandum defines the quantitative targets described in the memorandum of economic and financial policies (MEFP) for the period June 30, 2010-June 30, 2013 supported by the IMF Policy Support Instrument (PSI), and sets out the data reporting requirements. This Technical memorandum of understanding (TMU) supersedes the TMU issued in IMF Country Report No. 10/200.

\section{Quantitative Program Targets}

2. The quantitative program will be assessed through assessment criteria (AC) and indicative targets (IT) for the duration of the program.

3. AC will apply to the following indicators for end-June and end-December (the test dates) throughout the program period; other dates are IT:

- Floor on stock of net foreign assets (NFA) of the National Bank of Rwanda (NBR);

- Ceiling on stock of reserve money;

- Ceiling on flow net domestic financing (NDF) of the central government;

- Ceiling on contracting or guaranteeing of new nonconcessional external debt by the public sector; and

- Ceiling on stock of external payment arrears of the public sector.

4. IT targets apply to the following indicators throughout the program period:

- Floor on flow domestic revenue collection of the central government;

- Ceiling on flow net accumulation of domestic arrears of the central government;

- Ceiling on stock of consolidated domestic debt of the public sector; and

- Floor on flow priority spending.

5. Assessment criteria on contracting or guaranteeing of new nonconcessional external debt by the public sector and stock of external payment arrears of the public sector are applicable on a continuous basis for the duration of the program.

6. Program exchange rates. For accounting purposes, the following program exchange rates which are end-December 2009 rates apply for 2010 and 2011: 


\begin{tabular}{|l|l|}
\hline \multicolumn{2}{|c|}{ Program Exchange Rates (US\$ per currency unit, unless indicated otherwise) } \\
\hline Rwanda Franc (per US\$) & 571.24 \\
\hline Euro & 1.4599 \\
\hline British pound & 1.6241 \\
\hline Japanese Yen (per US\$) & 89.5610 \\
\hline SDR & 1.5822 \\
\hline
\end{tabular}

\section{A. Institutional Coverage of the Fiscal Sector}

7. The central government fiscal operation table comprises the treasury and line ministries, hereafter referred to as the government unless specified otherwise.

\section{B. Targets related to the Execution of the Fiscal Program}

\section{Ceiling on net domestic financing of the government}

8. A ceiling applies to NDF, which is measured cumulatively from December 31, 2009 for June 30, 2010; December 31, 2010; and June 30, 2011. Other dates are indicative targets

9. Definition. NDF of the government is defined as change in the sum of (i) net banking sector credit to the government and (ii) non-bank holdings of the government domestic debt.

10. Net banking sector credit to the government is defined as

- $\quad$ credit to the government from the banking system (as recorded in the monetary survey), including credit to the government, provinces and districts, outstanding consolidated government debt held by the banking system, ${ }^{1}$ government debt to the NBR incurred as a result of the 1995 devaluation (Rwf 9 billion), the overdraft to the prewar government (Rwf 2 billion) $)^{2}$, and overdraft with the NBR. Credit to the government will exclude treasury bills issued for monetary policy purposes by the NBR, and the proceeds of which are sterilized in deposits held as other NBR liabilities.

\footnotetext{
${ }^{1}$ Consisting of bank holdings of treasury bills, bonds (domestic), old development bonds (pre-1994 debt), new development bonds (including those used for recapitalization of banks), and other accounts receivables.

${ }^{2}$ The authorities will inform Fund staff of any substantive changes in government accounts with the banking system, which may affect the calculation of net bank claims.
} 
- $\quad$ minus total government deposits with the banking system (as recorded in the monetary survey), including the main treasury account, line ministries, the fund for assistance to genocide survivors, the Rwanda Revenue Authority, the electoral commission, the demobilization commission, fonds routier, privatization account, and any other autonomous public enterprises and public agencies over which the government has direct control over their deposits. Thus, this definition excludes any government deposits, over which the central government does not have any direct control (i.e., for project accounts, counterpart funds and fonds publics affectés).

11. Non-bank holdings of the government domestic debt consists of non-bank holdings of treasury bills, bonds (domestic and nonresident), old development bonds (pre-1994 debt), new development bonds (including those used for recapitalization of banks), and other accounts receivables.

\section{Adjusters to the NDF:}

- $\quad$ The ceiling on NDF will be adjusted upward by the amount of any shortfall between actual and programmed budgetary grants ${ }^{3}$ (defined in Table 2 of Quantitative AC and IT), up to a maximum adjustment of US\$80 million, evaluated in Rwanda francs at the program exchange rate. The ceiling will be adjusted downward by the amount of any excess of actual over programmed budgetary grants above US\$2 4 million, evaluated in Rwanda francs at the program exchange rate.

- $\quad$ The ceiling on NDF will be adjusted upward by the amount of expenditure for food imports in the case of a food emergency.

13. Reporting requirement. Data on NDF (showing separately treasury bills and government bonds outstanding, other government debt, and central government deposits), each type of debt to be shown by debt holder, and its adjusters will be transmitted on a monthly basis within five weeks from the end of each month. Deposits of the government with the NBR and with the commercial banks will be separated from the deposits of the public enterprises and autonomous public agencies and agencies that the government does not have any direct control over.

\section{Domestic revenues}

14. Definition. The floor on domestic government revenue is defined as total government revenue (tax and non-tax revenues), per the central government fiscal operation table, but excluding external grants, and privatization receipts.

\footnotetext{
${ }^{3}$ Budgetary grants exclude COMESA grants and HIPC grants.
} 
15. Reporting requirement. Detailed data on domestic revenues will be transmitted on a monthly basis within five weeks of the end of each month.

\section{Floor on priority expenditure}

16. The floor applies to priority spending of the government which is measured cumulatively from December 31, 2009.

17. Definition. Priority spending is defined as the sum of those recurrent expenditures, domestically-financed capital expenditures, and net lending that the government has identified as priority in line with the EDPRS. Priority expenditures are monitored through the computerized SIBET expenditure management system which tracks priority spending of the annual budget at the program level.

18. Reporting requirement. Data on priority expenditure will be transmitted on a monthly basis within five weeks of the end of each month.

\section{Net accumulation of domestic arrears of the government}

19. A ceiling applies to net accumulation of domestic arrears of the government which is measured cumulatively from December $31,2009 .^{4}$

20. Definition. The net accumulation of arrears is defined as the difference between the gross accumulation of new domestic arrears (measured as the difference between payment orders and actual payments related to payment orders issued) and gross repayment of any arrears outstanding on December 31, 2009 (including repayment of float in 2009 and the repayment of older arrears).

21. Reporting requirement. Data on repayment of domestic arrears and the remaining previous-year stock of arrears will be transmitted on a monthly basis within five weeks of the end of each month.

\section{Limits on External Debt}

\section{Limit on New Nonconcessional External Debt of the Public Sector}

22. A ceiling applies to the contracting and guaranteeing by the public sector of new nonconcessional borrowing debt with nonresidents (see below for the definition of the public sector, concessionality and debt). The ceiling is given in Table 2 of the MEFP which applies continuously from end-June 2010 to end-June 2013; it excludes the swap agreement of US\$50 million signed in November 2009 between the NBR and the IFC and US\$13.1 million for purchase of two air planes in 2009. The ceiling also excludes non concessional borrowing by one state owned commercial bank, the Bank of Kigali, which is assumed not to seek or be granted a government guarantee. The ceiling also applies to private debt for which official

\footnotetext{
${ }^{4}$ A negative target thus represents a floor on net repayment.
} 
guarantees have been extended, including future swaps involving foreign currency loans guaranteed by the public sector (see below for swaps), and which, therefore, constitute a contingent liability of the public sector.

23. Definition of the public sector. The public sector comprises the general government (the central government, the NBR, local governments which include provinces and districts) and entities in which the government holds a controlling stake - owning more than 50 percent of the shares or the ability to determine general corporate policy. ${ }^{5}$ This definition of public sector excludes the Bank of Kigali.

24. For program purposes, the guarantee of a debt arises from any explicit legal obligation of the public sector to service a debt in the event of nonpayment by the debtor (involving payments in cash or in kind), or from any implicit legal or contractual obligation of the public sector to finance partially or in full any shortfall incurred by the debtor.

\section{Definition of concessionality For program purposes, a debt is concessional if it} includes a grant element of at least 35 percent, calculated as follows: the grant element of a debt is the difference between the present value (PV) of debt and its nominal value, expressed as a percentage of the nominal value of the debt. The PV of debt at the time of its contracting is calculated by discounting the future stream of payments of debt service due on this debt. ${ }^{6}$ The discount rates used for this purpose are the currency specific commercial interest reference rates (CIRRs), published by the Organization for Economic Cooperation Development (OECD). For debt with a maturity of at least 15 years, the ten-year-average CIRR will be used to calculate the PV of debt and, hence, its grant element. For debt with a maturity of less than 15 years, the six-month average CIRR will be used. To both the ten-year and six-month averages, the same margins for differing repayment periods as those used by the OECD need to be added $(0.75$ percent for repayment periods of less than 15 years, 1 percent for 15 to 19 years, 1.15 percent for 20 to 29 years, and 1.25 percent for 30 years or more).

26. The definition of debt, for the purposes of the limit in the AC, is set out in point 9 of the Guidelines on Performance Criteria with Respect to External Debt, effective December 1, 2009). It not only applies to the debt as defined in Point 9 of the Executive Board decision, but also to commitments contracted or guaranteed for which value has not been received. The

\footnotetext{
${ }^{5}$ Government control of an entity can be established based on the following criteria: (i) ownership of the majority of the voting interest; (ii) control of the board or other governing body; (iii) control of the appointment and removal of key personnel; (iv) control of key committees of the entity; (v) golden shares and options; (vi) regulation and control; (vii) control by a dominant public sector customer or group of public sector customers; and (viii) control attached to borrowing from the government.

${ }^{6}$ The calculation of concessionality will take into account all aspects of the loan agreement, including maturity, grace period, payment schedule, upfront commissions, and management fees.
} 
definition of debt set forth in No. 9 of the Guidelines on Performance Criteria with Respect to External Debt in Fund Arrangements reads as follows:

(a) The term "debt" will be understood to mean a current, i.e., not contingent, liability, created under a contractual arrangement through the provision of value in the form of assets (including currency) or services, and which requires the obligor to make one or more payments in the form of assets (including currency) or services, at some future point(s) in time; these payments will discharge the principal and/or interest liabilities incurred under the contract. Debts can take a number of forms, the primary ones being as follows:

(i) loans, i.e., advances of money to the obligor by the lender made on the basis of an undertaking that the obligor will repay the funds in the future (including deposits, bonds, debentures, commercial loans and buyers' credits) and temporary exchanges of assets that are equivalent to fully collateralized loans under which the obligor is required to repay the funds, and usually pay interest, by repurchasing the collateral from the buyer in the future (such as repurchase agreements and official swap arrangements);

(ii) suppliers' credits, i.e., contracts where the supplier permits the obligor to defer payments until sometime after the date on which the goods are delivered or services are provided; and

(iii) leases, i.e., arrangements under which property is provided which the lessee has the right to use for one or more specified period(s) of time that are usually shorter than the total expected service life of the property, while the lesser retains the title to the property. The debt is the present value (at the inception of the lease) of all lease payments expected to be made during the period of the agreement excluding those payments that cover the operation, repair, or maintenance of the property.

(b) Under the definition of debt set out in point 9(a) above, arrears, penalties, and judicially awarded damages arising from the failure to make payment under a contractual obligation that constitutes debt. Failure to make payment on an obligation that is not considered debt under this definition (e.g., payment on delivery) will not give rise to debt.

\section{Limit on the stock of external payment arrears}

27. A continuous assessment criterion applies to the non-accumulation of payment arrears on external debt contracted or guaranteed by the public sector. External payment arrears consist of external debt service obligations (principal and interest) that have not been paid at the time they are due, as specified in the contractual agreements, but shall exclude arrears on obligations that are subject to rescheduling. 


\section{Consolidated Domestic Debt of the Public Sector (DD)}

28. For program purposes, DD excludes treasury bills issued by the NBR for monetary policy purposes. The ceiling on DD applies to domestic commitments contracted or guaranteed by the public sector. This also applies to private debt for which official guarantees have been extended either implicitly or explicitly. The authorities would inform Fund staff of any changes in debt position of public sector entities.

\section{Adjusters:}

- In the case of a shortfall in programmed grants, the ceiling on consolidated domestic debt of public sector will be adjusted upward by the same amount as the increase in the ceiling in the NDF, but capped per paragraph 12 .

- $\quad$ The ceiling on the DD will be adjusted upward by the amount of expenditure for food imports in the case of a food emergency.

29. Reporting requirement. Data on domestic debt of the public sector, including treasury bills issued by the NBR for monetary policy purposes, will be transmitted on a monthly basis within five weeks of the end of each month.

\section{Targets for Monetary Aggregates}

\section{Net foreign assets of the National Bank of Rwanda (NFA)}

30. A floor applies to the NFA of the NBR for June 30, 2010, December 31, 2010 and June 30, 2011 targets. Other dates are indicative targets throughout the program.

31. Definition. NFA of the NBR in Rwanda francs are defined, consistent with the definition of the Special Data Dissemination Standard (SDDS) template, as external assets readily available to, or controlled by, the NBR net of its external liabilities. Pledged or otherwise encumbered reserve assets (including swaps) are to be excluded; such assets include, but are not limited to, reserve assets used as collateral or guarantee for third party external liabilities. Foreign assets and foreign liabilities in U.S. dollars are converted to Rwanda francs by using the U.S. dollar/Rwanda franc program exchange rate. Foreign assets and liabilities in other currencies are converted to U.S. dollars by using the actual end-ofperiod U.S. dollar/currency exchange rate. Foreign liabilities include, inter alia, use of IMF resources (CCFF and post-conflict emergency assistance purchases and SAF/ESAF/ECF disbursements).

\section{Adjusters:}

- The floor on NFA will be adjusted downward by the amount of any shortfall between actual and programmed budgetary grants. This adjustment will be capped at the equivalent of US\$80 million, evaluated in Rwanda francs at the program exchange rate. In the case of excess of actual over programmed budgetary grants, the floor of the NFA remains unchanged for the first US\$24 million. Subsequently, the floor will be adjusted upwards by any amount in excess of US\$24 million. 
- $\quad$ The floor on NFA will be adjusted downward by the amount of expenditure for food imports in the case of a food emergency.

33. Reporting requirement. Data on foreign assets and foreign liabilities of the NBR will be transmitted on a weekly basis within seven days of the end of each week. This transmission will include daily and weekly data on the NBR's foreign exchange liabilities to commercial banks (including required reserves with the NBR) and the exchange rate used for their conversion into Rwanda francs will be shown separately.

\section{Reserve money}

34. A ceiling applies to the stock of reserve money for the June 30, 2010, December 31, 2010 and June 30, 2011 targets. Other dates are indicative targets throughout the program.

35. The stock of reserve money target for a given quarter will be calculated as the arithmetic average of the stock of reserve money at the end of each calendar month in the quarter. Daily average of all the three months in the quarter will constitute the actual reserve money to be compared with the target.

36. Reserve money is defined as the sum of currency in circulation, commercial banks' reserves, and other nonbank deposits at the NBR.

\section{Adjuster:}

- $\quad$ The ceiling on the stock of reserve money will be adjusted symmetrically for a change in the required reserve ratio of commercial banks. The adjustor will be calculated as (new reserve ratio minus program baseline reserve ratio) multiplied by actual amount of liabilities (Rwanda Franc plus foreign-currency denominated) in commercial banks.

38. Reporting requirement. Data on reserve money will be transmitted on a weekly basis within seven days of the end of each week. This transmission will include a daily and a weekly balance sheet of the NBR which will show all items listed above in the definitions of reserve money.

\section{Other Data Reporting Requirements}

39. For the purposes of program monitoring, the Government of Rwanda will provide the data listed in Table 1 below, weekly data within seven days of the end of each week; monthly data within five weeks of the end of each month; annual data as available.

40. The authorities will inform the IMF staff in writing at least ten business days (excluding legal holidays in Rwanda or in the United States) prior to making any changes in economic and financial policies that could affect the outcome of the financial program. Such policies include but are not limited to customs and tax laws (including tax rates, exemptions, allowances, and thresholds), wage policy, and financial support to public and private 
enterprises. The authorities will similarly inform the IMF staff of any nonconcessional external debt contracted or guaranteed by the government, the NBR, or any statutory bodies, and any accumulation of new external payments arrears on the debt contracted or guaranteed by these entities. The authorities will furnish an official communication to the IMF describing program performance of quantitative and structural assessment criteria and benchmarks within 8 weeks of a test date. The authorities will on a regular basis submit information to IMF staff with the frequency and submission time lag as indicated in Table 1. The information should be mailed electronically to AFRRWA@IMF.ORG . 
Table 1. Summary of Reporting Requirements

\begin{tabular}{|c|c|c|c|}
\hline & $\begin{array}{r}\text { Frequency } \\
\text { of } \\
\text { Data }^{6}\end{array}$ & $\begin{array}{r}\text { Frequency } \\
\text { of } \\
\text { Reporting }^{6}\end{array}$ & $\begin{array}{r}\text { Frequency } \\
\text { of } \\
\text { Publication }{ }^{6}\end{array}$ \\
\hline Exchange Rates & D & W & D \\
\hline $\begin{array}{l}\text { International Reserve Assets and Reserve Liabilities of the } \\
\text { Monetary Authorities }{ }^{1}\end{array}$ & W & W & M \\
\hline Reserve/Base Money & W & W & M \\
\hline Broad Money & M & M & M \\
\hline Central Bank Balance Sheet & W & W & M \\
\hline Consolidated Balance Sheet of the Banking System & M & M & M \\
\hline Interest Rates ${ }^{2}$ & M & M & M \\
\hline Consumer Price Index & M & M & M \\
\hline $\begin{array}{l}\text { Composite Index of Economic Activity (CIEA) and sub- } \\
\text { components compiled by the NBR }\end{array}$ & M & M & M \\
\hline $\begin{array}{l}\text { Revenue, Expenditure, Balance and Composition of Financing }{ }^{3} \\
- \text { - General Government }{ }^{4}\end{array}$ & M & M & M \\
\hline $\begin{array}{l}\text { Revenue, Expenditure, Balance and Composition of } \\
\text { Financing }{ }^{3} \text { - Central Government }\end{array}$ & M & M & M \\
\hline Comprehensive list of tax and non tax revenues & M & M & M \\
\hline Comprehensive list of domestic arrears of the government & M & M & M \\
\hline The ten (10) largest components of transfers in the fiscal table & M & M & M \\
\hline Social security contributions & M & M & M \\
\hline $\begin{array}{l}\text { Stocks of public sector and public-Guaranteed Debt as reported } \\
\text { by MINECOFIN and NBR }\end{array}$ & A & A & A \\
\hline External Current Account Balance & A & SA & A \\
\hline Exports and Imports of Goods and Services & A & A & A \\
\hline GDP/GNP & A & SA & Q \\
\hline
\end{tabular}

${ }^{1}$ Includes reserve assets pledged or otherwise encumbered as well as net derivative positions.

${ }^{2}$ Both market-based and officially-determined, including discount rates, money market rates, rates on treasury bills, notes and bonds.

${ }^{3}$ Foreign, domestic bank, and domestic nonbank financing.

${ }^{4}$ The general government consists of the central government (budgetary funds, extra budgetary funds, and social security funds) and state and local governments.

${ }^{5}$ Including currency and maturity composition.

${ }^{6}$ Daily (D); Weekly (W); Monthly (M); Quarterly (Q); Annually (A); Semi-annually (SA); Irregular (I). 


\section{APPENDIX II}

\section{RWANDA-SOURCES OF GROWTH USING A GROWTH ACCOUNTING FRAMEWORK ${ }^{1}$}

\section{A. Introduction and Summary}

1. Rwanda has maintained remarkable economic growth for more than a decade. Real GDP growth averaged about 8 percent a year during 1998-2009, up from 2 percent a year in the 1980s. The growth reflects a strong rebound from the conflict in 1994, but also has been underpinned by government's prudential macroeconomic policies and pro-market structural reforms, supported by the successive Fund-supported programs, as well as substantive debt relief and scaling up of aid.

2. Now the key question is - is the growth sustainable? To answer the question, it is essential to investigate where growth comes from. During the period, investment increased significantly which reduced a severe infrastructure gap, while the population grew by nearly 50 percent. If the economic growth is solely driven by factor accumulation (capital and labor), then the recent high growth cannot be sustained in the future, given that the planned fiscal consolidation and the projected decline in official grants would reduce capital formation.

3. The analysis of the sources of growth has methodological limitations. In this appendix, the sources of Rwanda's economic growth are examined using a growth accounting framework. Although the framework is widely utilized in empirical studies, it is known that it has limitations, which mainly come from the fact that productivity is measured as a residual. As a result, the measured productivity contains not only gains in economic efficiency, but also a number of other factors, such as external shocks, political stability, climate conditions, and measurement errors. Another shortcoming, though specific to Rwanda, is that labor inputs cannot be adjusted for quality of human capital and working hours, due to the lack of a labor force survey for Rwanda. Thus improvement in human capital such as through educational attainment will be registered as a part of productivity growth.

4. Nevertheless, the exercise provides a useful perspective on Rwanda's economic growth. The exercise illustrates that a large part of Rwanda's impressive economic growth over the past decade can be explained by productivity gains, and growth could be further accelerated over the medium term through mobilizing private investment and enhancing productivity. The details of the methodology and data are shown in Section $\mathrm{B}$, followed by Section $\mathrm{C}$ which reports on the findings.

\footnotetext{
${ }^{1}$ Prepared by Masafumi Yabara (African Department).
} 


\section{B. Methodology and Data}

5. The methodology used in this appendix is the one widely adopted in empirical research on growth accounting and specifically taken from Tahari et al. (2004). ${ }^{2}$ A standard Cobb-Douglas production function is written as:

$$
Y_{t}=A_{t} K_{t}^{\alpha} L_{t}^{1-\alpha}
$$

where $Y$ is output, $A$ represents total factor productivity (TFP), $K$ is physical capital, $L$ is labor force, $\alpha$ is the share of capital in national income, and $t$ represents a year.

6. Taking natural logarithm of the function and differentiating with respect to time gives:

$$
\frac{\dot{Y}}{Y}=\frac{\dot{A}}{A}+\alpha \frac{\dot{K}}{K}+(1-\alpha) \frac{\dot{L}}{L}
$$

where the dotted variables denote time derivatives. The equation indicates that economic growth can be decomposed into contributions from TFP and capital and labor inputs. It also means that once the growth of output, capital, and labor force are obtained, TFP growth can be estimated as a residual, based on an assumption about $\alpha$.

7. Output $Y$ from 1960 to 2009 is measured by GDP at constant prices, taken from the IMF World Economic Outlook (WEO) database. For capital $K$, it is assumed that the initial capital-output ratio in 1960 is 1.5 and capital depreciates by 6 percent every year, while it is augmented by investment each year. Investment is measured by gross fixed capital formation at constant prices, also obtained from the WEO database. Labor force data is obtained from the World Bank Development Indicators database. ${ }^{3}$ IMF staff projections are used for projections after 2010. $\alpha$ is set at 0.4 , following Tahari et al. (2004), which is in line with an estimate of the capital share for Rwanda by Coulibaly et al. (2008). ${ }^{4}$ The findings are robust if $\alpha$ is alternatively set to be 0.3 , a common assumption in studies of TFP growth in developed economies.

\footnotetext{
${ }^{2}$ Tahari, Amor, Dhaneshwar Ghura, Bernardin Akitoby, and Emmanuel Brou Aka, 2004, "Sources of Growth in Sub-Saharan Africa," IMF Working Paper 04/176 (Washington: International Monetary Fund).

${ }^{3}$ As the data is available only through 2008, it is assumed that labor force grows in 2009 by the average growth rate of the last five years (2004-2008), 2.9 percent.

${ }^{4}$ Coulibaly, Kalamogo, Kene Ezemenari, and Neal Duffy, 2008, "Productivity Growth and Economic Reform: Evidence from Rwanda," World Bank Policy Research Working Paper No. 4552 (Washington: World Bank).
} 


\section{Sources of Rwanda's Growth from 1961 to 2009, and beyond}

\section{Rwanda's high economic growth in the last decade has been driven not only by} accumulation of capital and labor, but also by productivity gains. In particular, the contribution of TFP to output growth rose to 2.1 percent on average for 1998-2009, making a clear distinction from previous decades. Looking at the recent period of 2004-2009, capital and TFP played more important role in economic growth, each of which contributed 2.9 percent to output growth on average (Table 1). ${ }^{5}$ These findings are encouraging, as they suggest that the government's policies have succeeded not only in increasing investment in physical capital, but also in enhancing the efficiency of the whole economy, although, as stated earlier, TFP includes other factors such as investment in human capital.

Table 1. Sources of Growth for 1961-2009

\begin{tabular}{ccccc}
\hline Period & $\begin{array}{c}\text { Real GDP } \\
\text { Growth 1/ }\end{array}$ & $\begin{array}{c}\text { Physical } \\
\text { Capical }\end{array}$ & Labor & TFP \\
\hline $1961-2009$ & $3.9 \%$ & $1.4 \%$ & $1.4 \%$ & $0.4 \%$ \\
$1961-1993$ & $2.7 \%$ & $1.3 \%$ & $1.0 \%$ & $0.2 \%$ \\
$1998-2009$ & $7.6 \%$ & $2.3 \%$ & $2.9 \%$ & $2.1 \%$ \\
$2004-2009$ & $7.8 \%$ & $2.9 \%$ & $1.7 \%$ & $2.9 \%$ \\
\hline 1/ Values do not exactly agree with the sum of the \\
Contributions from the three factors, due to approximation.
\end{tabular}

9. Compared to neighboring countries, economic growth in Rwanda has been driven more by rise in productivity. Applying the same methodology to four countries comprising the rest of East African Community (EAC), the share of contribution of productivity to output growth during 1998-2009 is higher for Rwanda than for the other EAC countries, except for Tanzania (Figure 1). About 28 percent of output growth in Rwanda is derived from TFP gains, while only 13 percent of real GDP growth is attributable to TFP increases in the other EAC countries, on average.

10. Economic recovery of Rwanda in $\mathbf{2 0 1 0}$ is largely supported by strong recovery of TFP. Staff estimates that real GDP growth will reach 6.5 percent in 2010 up from 4.1 percent in 2009. According to growth accounting, this recovery is largely explained by significant improvement of TFP to 1.3 percent in 2010 after registering a negative contribution in 2009, caused by the domestic liquidity crisis and the global financial turmoil (Figure 1). ${ }^{6}$

\footnotetext{
${ }^{5}$ The high productivity gains since 1998 obviously pick up the rebound from the conflict in 1994: however, the further rise in productivity in the recent years illustrates that the rebound cannot explain all the increases in productivity after the conflict.

${ }^{6}$ In the following arguments, it is assumed that labor force growth for 2010-2015 is the same as in 2009, 2.9 percent a year, the average of 2004-2008, due to the fact that there is no reliable data to make a forecast of labor market developments.
} 
11. Over the medium term, high economic growth is expected to be maintained, underpinned by the government's strategic investments and rise in productivity. Output growth is expected to hit its peak of 7 percent in 2012, and then stabilize at 6.5 percent. This growth path is driven by government's strategic investments, as well as gradual rise in TFP which is projected to reach 2.2 percent in 2012 and remain at that level in the following years. The TFP rise offsets the expected decline in government's investments after 2012, resulting from fiscal consolidation and reduced official grants (Figure 1).

12. Rwanda's economy could potentially grow by 8.4 percent over the medium term, provided that (i) investment is scaled up to the level of global average; (ii) productivity growth accelerates and remains elevated; and (iii) there are no adverse shocks. The projected potential output growth of 8.4 percent is premised on simultaneous occurrence of highly favorable factors: (i) investment will further increase after 2012, reaching 25 percent of GDP in 2015, as opposed to the staff projection that investment will gradually decrease to 20.6 percent of GDP by 2015, (ii) productivity growth will accelerate to 2.9 percent in 2013 , the high average TFP growth over 2004-2009, and then stabilize at the level; and (iii) there are no shocks with adverse effects on output (Figure 1).

13. Mobilizing private resources through maintaining macroeconomic stability and pro-market structural reforms is essential in maximizing Rwanda's potential economic growth. The investment-GDP ratio of 25 percent is much higher than the projected average of Sub-Saharan African countries, 21 percent in 2015, and is equivalent to the world average. In order for this best case scenario to materialize in the midst of the planned fiscal consolidation and decline in external grants, it is essential that the government maintains macroeconomic stability and accelerates market-friendly structural reforms, so that private investment is further mobilized and resources are aptly utilized to enhance the productivity of the economy. 
Figure 1. Rwanda: Sources of Growth

Growth of both output and productivity has significantly increased after 1998...

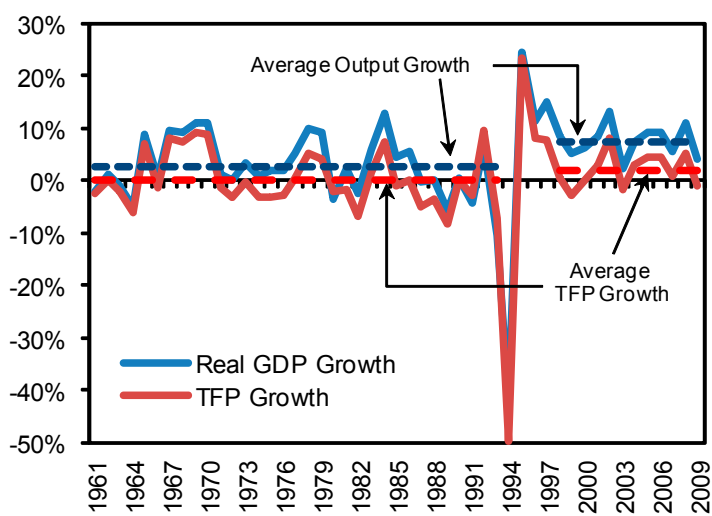

Rwanda's growth has been driven more by productivity gains, compared to other East African countries.

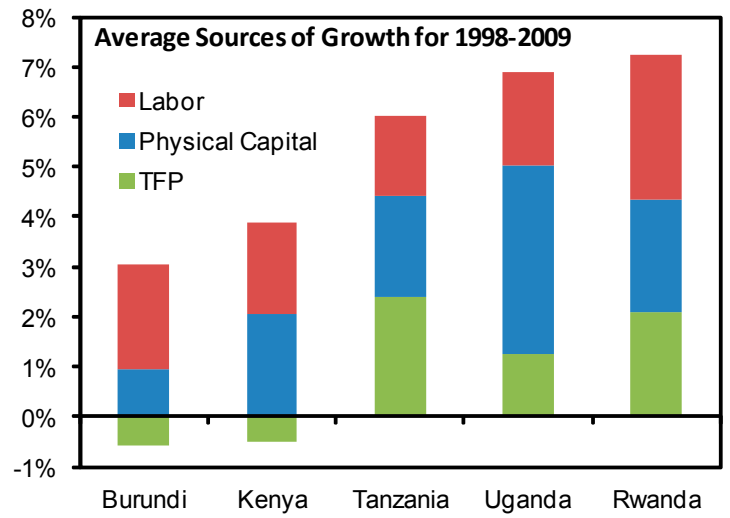

Rwanda's economy could potentially grow by about 8.4 percent over the medium term...

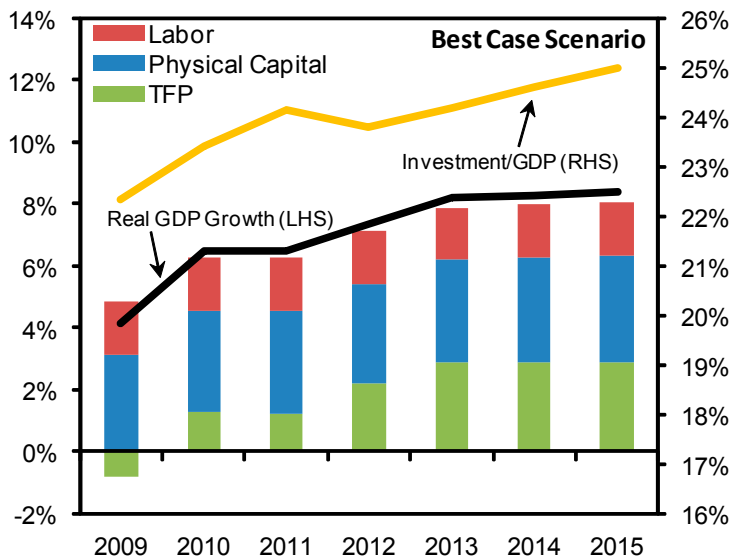

....and the contributions of capital and productivity to growth have further increased in the recent years.

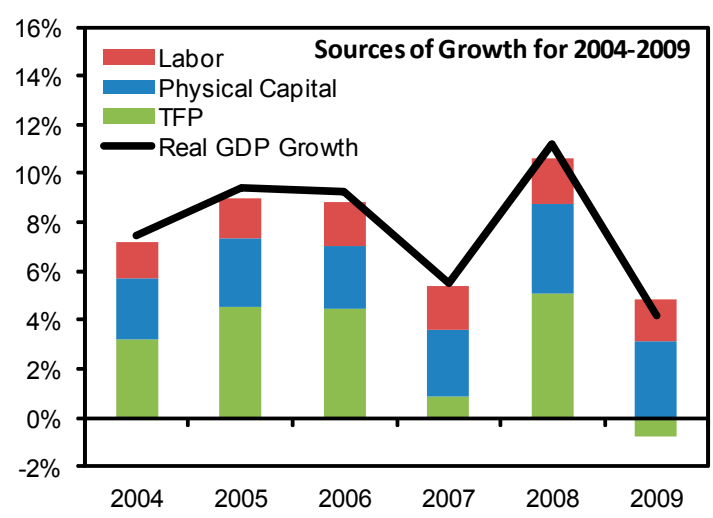

Robust growth is expected to be maintained over the medium term, underpinned by public investment and enhanced productivity.

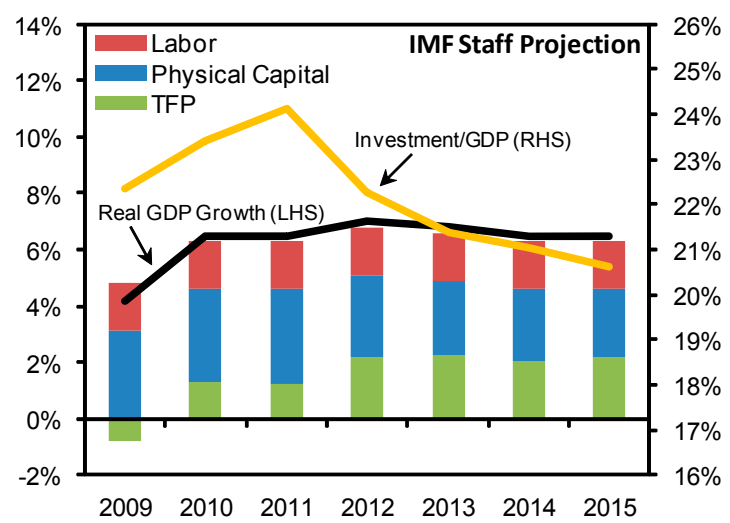

...provided that investment is scaled up and productivity growth accelerates and remains elevated.

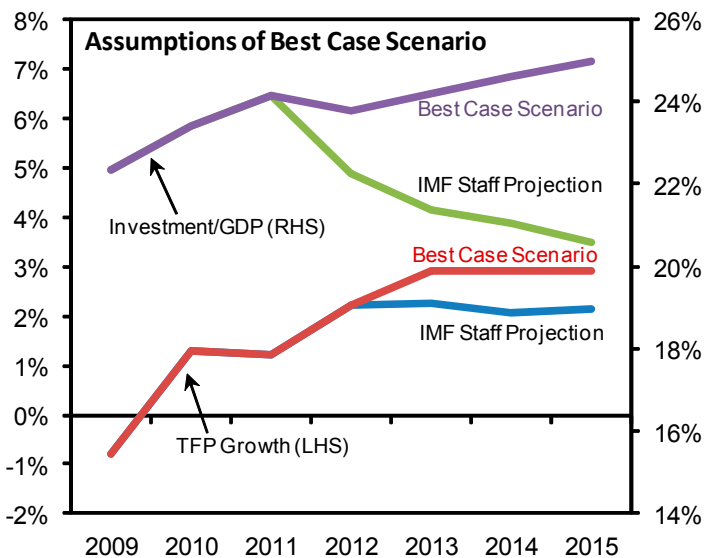

Sources: IMF World Economic Outlook database, World Bank Development Indicators database, and IMF staff estimates and projections. 
INTERNATIONAL MONETARY FUND

\title{
RWANDA
}

\section{Staff Report for the 2010 Article IV Consultation, First Review Under the Policy Support Instrument, and Modification of Assessment Criteria- Informational Annex}

\author{
Prepared by the African Department \\ (In collaboration with other Departments) \\ Approved by Saul Lizondo and Christian Mumssen
}

December 6, 2010

- Relations with the Fund. Describes financial and technical assistance by the IMF and provides information on the safeguards assessment and exchange system.

- Joint World Bank-IMF Work Program. Outlines the Joint Management Action Plan through June 2011.

- $\quad$ Statistical Issues. Assesses the quality of statistical data. Although economic data are generally adequate for surveillance and program monitoring, weaknesses, particularly in national accounts and balance of payments, hamper economic analysis. 


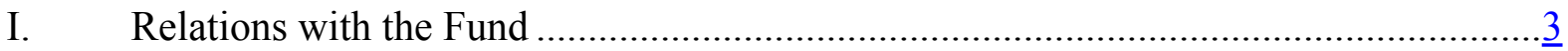

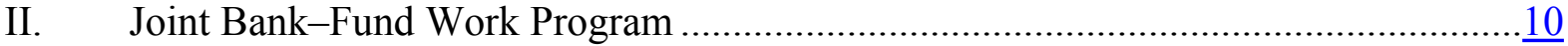

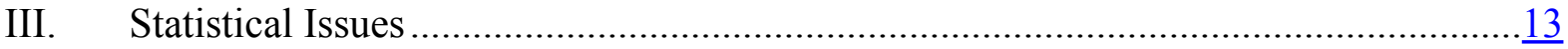




\section{APPENDIX I. RWANDA: RELATIONS WITH THE FUND}

(As of October 31, 2010)

I. Membership Status: Joined: September 30, 1963;

$\underline{\text { Article VIII }}$

\section{General Resources Account:}

SDR Million

Quota

80.10

\%Quota

Fund holdings of currency

80.11

100.00

Reserve Tranche Position

0.00

100.02

0.00

III. SDR Department:

SDR Million

\%Allocation

76.82

100.00

Holdings

83.47

108.65

IV. Outstanding Purchases and Loans:

PRGF Arrangements ${ }^{1}$

SDR Million

9.67

\%Quota

12.07

\section{Latest Financial Arrangements:}

Date of

Expiration

Amount Approved

Amount Drawn

Type

Arrangement

PRGF

June 12, 2006

Date

(SDR Million)

(SDR Million)

PRGF

August 12, 2002 June 11, 2006

8.01

8.01

4.00

4.00

PRGF

June 24, 1998 April 30, 2002

71.40

61.88

\section{Payments to Fund ${ }^{3}$}

(SDR Million; based on existing use of resources and present holdings of SDRs):

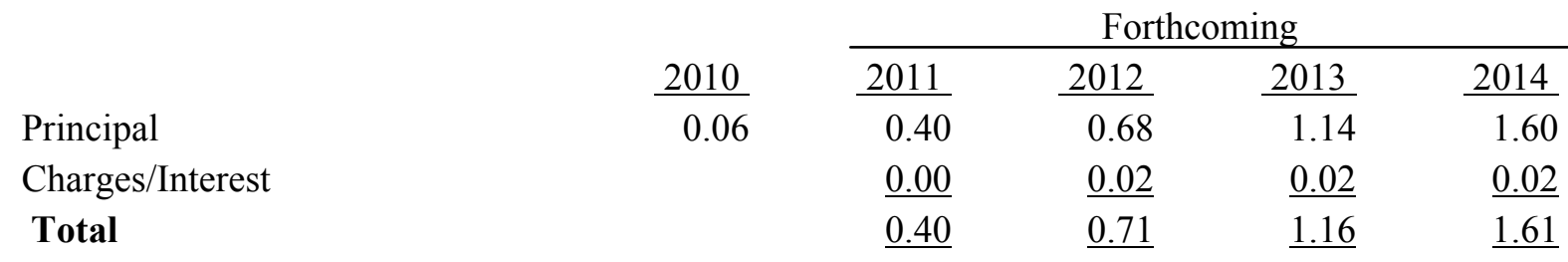

\footnotetext{
${ }^{1}$ Now known as Extended Credit Facility (ECF).

${ }^{2}$ On June 4, the PRGF was extended from June 11, 2009 to August 14, 2009, to allow time for the completion of the sixth and final review, and for making the final disbursement under the PRGT arrangement.

${ }^{3}$ When a member has overdue financial obligations outstanding for more than three months, the amount of such arrears will be shown in this section.
} 
VII. Implementation of HIPC Initiative:

I. Commitment of HIPC assistance

Decision point date

Assistance committed by all creditors

(US\$ million) ${ }^{4}$

Of which: IMF assistance (US\$ million)

(SDR equivalent in millions)

Completion point date
Enhanced

framework

Dec 2000

46.79

Apr 2005

II. Disbursement of IMF assistance (SDR million)

Assistance disbursed

Interim assistance

Completion point balance

Additional disbursement of interest income ${ }^{5}$

Total disbursements

50.56

\section{Implementation of Multilateral Debt Relief Initiative \\ (MDRI) \\ I. MDRI -eligible debt (SDR Million) ${ }^{6}$ \\ Financed by: MDRI Trust \\ Remaining HIPC resources

II. Debt Relief by Facility (SDR million)

Delivery Date

January 2006
GRA

N/A
PRGT

Total

52.74

\footnotetext{
${ }^{4}$ Assistance committed under the original framework is expressed in net present value (NPV) terms at the completion point, and assistance committed under the enhanced framework is expressed in NPV terms at the decision point. Hence these two amounts cannot be added.

${ }^{5}$ Under the enhanced framework, an additional disbursement is made at the completion point corresponding to interest income earned on the amount committed at the decision point but not disbursed during the interim period.

${ }^{6}$ The Multilateral Debt Relief Initiative (MDRI) provides 100 percent debt relief to eligible member countries that are qualified for the assistance. The debt relief covers the full stock of debt owed to the Fund as of end2004 which remains outstanding at the time the member qualifies for such debt relief. The MDRI is financed by bilateral contributions and the Fund's own resources, as well as the resources already disbursed to the member under the HIPC Initiative (see Section VII above).
} 
Decision point-point at which the IMF and the World Bank determine whether a country qualifies for assistance under the HIPC Initiative and decide on the amount of assistance to be committed.

Interim assistance - amount disbursed to a country during the period between decision and completion points, up to 20 percent annually and 60 percent in total of the assistance committed at the decision point (or 25 percent and 75 percent, respectively, in exceptional circumstances).

Completion point - point at which a country receives the remaining balance of its assistance committed at the decision point, together with an additional disbursement of interest income as defined in footnote 4 above. The timing of the completion point is linked to the implementation of pre-agreed key structural reforms (i.e., floating completion point).

\section{Safeguards Assessments:}

The 2007 safeguards update assessment noted that since 2003, the National Bank of Rwanda (NBR) strengthened its own safeguards: External audits were completed on time, the Committee of Auditors became operational, and the Internal Audit Department helped in the strengthening of controls over monetary program data. The update assessment's priority recommendations concerned timely publication of the audited financial statements, further improving external audit arrangements, and full implementation of IFRS. Safeguards policy does not require an update safeguards assessment in the case of the non-financial arrangement with the Fund. However, such assessment may be voluntary requested by the country, and the NBR has made a formal request for the update assessment.

\section{Exchange System:}

The currency of Rwanda is the Rwandan franc. On December 1998, Rwanda accepted the obligations under Article VIII, Sections 2, 3 and 4 of the IMF and maintains a system free of restrictions on the making of payments and transfers for current international transactions. As of November 9, 2010 the official exchange rate was RWF 591.80 per U.S. dollar. Since January 2010, the Rwanda franc has gradually depreciated against the dollar in a 2 percent band. Under the revised classification of the exchange rate arrangements, effective January 4, 2010 , the de facto exchange rate arrangement has been reclassified to a crawl-like arrangement from a stabilized arrangement. The de jure exchange rate arrangement is classified as floating. The official exchange rate (called the Average Reference Rate or ARR) is calculated on a daily basis by the National Bank of Rwanda (NBR) as a 5-day moving average of (i) the exchange rate used for transactions between commercial banks and 
their customers and (ii) the exchange rate used by NBR with its customers. ${ }^{7}$ The NBR applies a margin of $+/-0.6$ percent to the previous days' ARR to derive current day's customer rate and ensures that the customer rate used for transactions with the government and market rates do not differ by more than $2 \%$. With a view to introducing more flexibility in its exchange rate policy, since March 24, 2010, NBR introduced an exchange rate corridor framework.

\section{Article IV Consultation:}

Rwanda is on the revised 24-month consultation cycle. The Executive Board discussed the staff report for the 2008 Article IV consultation (IMF Country Report No. 09/58) on January $12,2009$.

\section{FSAP Participation, ROSCs, and OFC Assessments:}

A Report on Observance of Standards and Codes on Fiscal Transparency (ROSC) was issued in July 2003. A Financial Sector Assessment Program (FSAP) took place in February 2005, and a FSAP update is planned in February 2011. Rwanda has not had an Offshore Financial Center (OFC) assessment.

\section{Policy Support Instrument (PSI):}

A three-year PSI program was approved on June 16, 2010, with an effective date of June 30, 2010 .

\section{XIV . Technical Assistance and Future Priorities:}

\section{List of Technical Assistance Missions}

2004 AFRITAC East expert on financial regulations.

2004 AFRITAC East mission on treasury reforms.

2004 AFRITAC East expert on implementing cash flow planning and banking arrangements.

2004 FAD tax administration expert on strengthening of revenue administration.

2004 FAD mission on revenue administration.

2004 MFD/LEG mission on Anti-Money Laundering and Combating the Financing of Terrorism.

2004 MFD expert on banking supervision and regulation.

2004 MFD expert on monetary policy, monetary operations, and money markets.

\footnotetext{
${ }^{7}$ From January 16th, 2009 to January 11th, 2010, The NBR's average reference rate (ARR) was calculated as the ten days weighted moving average. With effect from January 12th, 2010, the ARR has changed to 5 days moving average.
} 
2004 MFD missions on on-site banking supervision.

2005 AFRITAC East expert follow up on cash management.

2005 MFD/LEG mission on Anti-Money Laundering and Combating the Financing of Terrorism.

2005 MFD mission on financial statements of specific bank.

2005 MFD-WB joint FSAP mission.

2005 LEG mission on customs legislation.

2005 STA mission on Balance of Payments statistics.

2005 LEG mission on tax legislation.

2005 FAD mission on public accounting: decentralized accounting for central government.

2005 FAD expert on tax administration.

2005 MFD resident expert on monetary operations, monetary policy, money markets.

2005 MFD expert on banking supervision.

2005 LEG mission on drafting an amendment to the banking law.

2005 MFD mission on banking supervision and bank restructuring.

2006 AFRITAC East experts on establishing intergovernmental fiscal unit in the MOF.

2006 FAD advisor trade facilitation.

2006 MFD FSAP-follow up advisory mission on monetary and foreign exchange operations and NBR internal audit.

2006 LEG mission to strengthen legal and regulatory framework for bank supervision.

2006 AFRITAC East advisors on finalization of OBL and financial regulations

2007 AFRITAC East advisors on workshops for implementation of OBL and financial regulations.

2007 MCM expert on bank restructuring.

2007 MCM expert on foreign exchange operations.

2008 LEG mission to assist the Ministry of Finance in modernizing the tax system.

2008 LEG mission on banking legislation.

2008 LEG review of Article VIII obligations.

2008 MCM expert on foreign exchange operations.

2008 MCM mission to assist in building up internal audit in the central bank.

2008 FAD expert on revenue administration.

2008 AFRITAC East advisors on (i) improving the budget preparation process and budget accounting, and (ii) changing to the GFS2001- based economic classification (jointly with STA).

2008 MCM mission on monetary policy operations, foreign exchange operations, and assessment of the financial health of banks.

2008 AFRITAC East advisors on enhancement of national accounts estimation.

2009 MCM mission on liquidity management.

2009 MCM mission on bank supervision.

2009 STA mission on rebasing consumer and producer price indices.

2009 FAD/AFRITAC East mission to review progress and set the program for TA in budget reform and PFM.

2009 FAD/AFRITAC East mission on customs risk management and valuation. 
2009 AFRITAC East advisors on (i) enhancing comprehensiveness and transparency of the fiscal budget and (ii) reform strategy for introduction of program budgeting.

2009 AFRITAC East advisors on quarterly GDP compilation.

2009 AFRITAC East workshop on national accounts.

2009 AFRITAC East advisors on (i) developing a framework for adopting a capital charge for market risk, (ii) enhancements to offsite surveillance system, and (iii) payment system modernization.

2009 AFRITAC East advisors on operational policy development and compliance management in revenue administration.

2009 AFRITAC East workshop on strengthening tax audit and collection enforcement.

2009 FAD/AFRITAC East mission on strengthening fiscal management.

2009 FAD technical assistance evaluation mission.

2009 FAD mission on tax Administration.

2009 FAD/AFRITAC East training in financial programming \& macro-fiscal analysis.

2009 FAD/AFRITAC East mission on bringing external funds on budget.

2009 FAD/AFRITAC East mission on improving budgeting of external funds and expenditure to local government.

2009 FAD/AFRITAC East mission to install expert on revenue administration.

2009 FAD mission on customs business strategy.

2009 FAD mission on customs post-clearance audit training and compliance.

2009 FAD training on tax audit.

2009 FAD mission on customs information technology.

2009 LEG mission on payments and settlements systems law.

2009 MCM mission on internal audit.

2009 MCM /AFRITAC mission on non bank PSs, stakeholder issues and NPs strategy implementations.

2009 MCM mission on financial stability.

2009 MCM mission on banking supervision.

$2009 \mathrm{MCM} / \mathrm{AFRITAC}$ East training in basic bank supervision skills.

$2009 \mathrm{MCM} / \mathrm{AFRITAC}$ East mission to assist the NBR to assess the current status of Rwanda's banking system.

2009 MCM mission on monetary policy and FOREX.

2009 STA/AFRITAC East mission on improving the PPI.

2009 STA AFRITAC East mission on consumer price statistics.

2009 STA/AFRITAC East mission to assist in launching and facilitating discussions on Rwanda's national accounts compilation.

2009 STA/AFRITAC East mission on quarterly national accounts compilation.

2009 STA/AFRITAC East mission on monetary policy and FOREX.

2010 STA/AFRITAC East mission on national accounts statistics.

2010 LEG mission on payment \& settlement systems.

$2010 \mathrm{MCM} / \mathrm{AFRITAC}$ East mission to develop examination procedures.

2010 STA mission to review data reporting systems. 
2010 FAD/AFRITAC East mission on the development of a central bank database.

2010 MCM mission on foreign exchange policies and operations.

2010 STA/AFRITAC East mission on national accounts statistics.

2010 MCM mission on supervision of Non-bank financial institutions.

2010 FAD mission on safeguards and fiscal investment

2010 MCM mission on bank supervision.

2010 MCM mission on foreign exchange policy.

2010 MCM mission on bank supervision.

2010 FAD mission on central bank database.

2010 MCM mission on consolidated supervision.

2010 FAD/EAST AFRITAC on PFM

2010 FAD/EAST AFRITAC on Revenue administration

\section{Future priorities}

The priorities for the Fund's technical assistance will remain in the area of monetary and exchange rate management, supervision of bank and nonbank financial institutions, public finance management, tax policy and administration, and compilation of national account statistics.

\section{Resident Representative:}

Mr. Dmitry Gershenson assumed his duties as Resident Representative in February 2009.

\section{Management Visit:}

The Deputy Managing Director, Mr. Portugal, visited Rwanda during May 3-5, 2007. 


\section{Appendix II. Rwanda: Joint Bank-Fund Work Program}

JUNE 2010-JUNE 2011

\begin{tabular}{llll}
\hline Title & Products/Activity & $\begin{array}{l}\text { Timing of mission (if } \\
\text { relevant) }\end{array}$ & $\begin{array}{l}\text { Expected delivery } \\
\text { date }\end{array}$ \\
\hline
\end{tabular}

\section{Mutual Information on Relevant Work Program}

Bank

Work

A. Strategy and Analytical Work

Program Multi-Year Education Policy Analysis

December 2010

Rwanda Capacity Filter - Sector Analysis

February 2011

Support for Strengthening Rwandan Social Safety Nets

April 2011

Sustainable Land Management

May 2011

Financial Sector Assessment Program Update

June 2011

Support for Civil Society Strengthening

June 2011

Technical Assistance for Poverty Monitoring

June 2011

Employment and Growth Policy Note

July 2011

Social Risk Management of Climate

October 2011

Technical Assistance for Public Expenditure Management

June 2012

\section{B. Ongoing and New Projects}

EAC Financial Sector Development and Regionalization

December 2010

Project

Economic Empowerment of Young Women

December 2010

Poverty Reduction Support Grant -VII

Transport Sector Support

February 2011

April 2011

Third Community Living Standards Grant

March 2011

Skills Development Project

Decentralization and Community Development

March 2011

Ongoing

Ongoing

Public Sector Capacity Building Project

Second Rural Sector Support Project

Second Emergency Demobilization and Reintegration Project

Ongoing

Ongoing

Ongoing

Land Husbandry, Water harvesting and Hillside Irrigation 


\begin{tabular}{|c|c|c|c|}
\hline Title & Products/Activity & $\begin{array}{l}\text { Timing of mission (if } \\
\text { relevant) }\end{array}$ & $\begin{array}{l}\text { Expecte } \\
\text { date }\end{array}$ \\
\hline & \multicolumn{2}{|c|}{$\begin{array}{l}\text { Rwanda Electricity Access Scale-up and Sector-wide approach } \\
\text { Project }\end{array}$} & Ongo \\
\hline & \multicolumn{2}{|c|}{ Sustainable Energy Development Project (GEF) } & Ongo \\
\hline & \multicolumn{2}{|c|}{ Integrated Management of Critical Ecosystem Project (GEF) } & Ongo \\
\hline & \multicolumn{2}{|c|}{ Poverty Reduction Support Grant -VI } & Ongo \\
\hline & \multicolumn{2}{|l|}{ E-Rwanda } & Ongo \\
\hline & \multicolumn{2}{|c|}{ Transport Sector Development } & Ongo \\
\hline & \multicolumn{2}{|c|}{ Competitiveness and Enterprise Project } & Ongo \\
\hline
\end{tabular}

IMF

$\underline{\text { A. Missions }}$

Work

Program

First Review Under the Policy October 2010

December 2010

Support Instrument

\section{B. Analytical Work.}

Some Considerations in the Design of a Liquidity

December 2010

Supervision Framework for Banks in Rwanda

Understanding the Exchange Rate Pass-Through to

December 2010

Domestic Prices in the EAC Region: Implications for

Prospects of Monetary Integration.

Estimating the behavioral Equilibrium Exchange Rate for

December 2010 the EAC Countries

Monetary Policy Transmission in EAC Countries

December 2010

\section{Technical Assistance}

Fiscal: Tax and customs administration; revenue forecasting and PFM, strengthen PPP Unit in MINECOFIN

Monetary: Monetary policy operations; bank liquidity; interbank markets in local currency and foreign exchange

Ongoing

Ongoing

Financial: Bank supervision

Ongoing

Statistics: National accounts and balance of payments

Ongoing 


\begin{tabular}{|c|c|c|}
\hline Title & $\begin{array}{l}\text { Timing of mission (if } \\
\text { relevant) }\end{array}$ & $\begin{array}{l}\text { Expected delivery } \\
\text { date }\end{array}$ \\
\hline \multicolumn{3}{|c|}{ II. Request for Work Program Inputs } \\
\hline \multirow{2}{*}{$\begin{array}{l}\text { Bank } \\
\text { Request } \\
\text { to Fund }\end{array}$} & $\begin{array}{l}\text { Impact of the global economic crisis on key macro indicators } \\
\text { and growth in Rwanda }\end{array}$ & Ongoing \\
\hline & Sharing macro-framework updates & As needed \\
\hline \multirow{2}{*}{$\begin{array}{l}\text { Fund } \\
\text { Request } \\
\text { to Bank }\end{array}$} & $\begin{array}{l}\text { Assessment of key infrastructure projects undertaken by the } \\
\text { government. }\end{array}$ & As needed \\
\hline & Assessment of the PFM and public service reform program. & As needed \\
\hline
\end{tabular}

\section{Agreement on Joint Products}

\begin{tabular}{lll}
\hline $\begin{array}{l}\text { Joint } \\
\text { products }\end{array}$ & $\begin{array}{l}\text { Public and External Debt Sustainability Analysis. } \\
\text { Collaborate together with other development partners on the } \\
\text { annual review of general budget support. }\end{array}$ & $\begin{array}{l}\text { Completed } \\
\text { Ongoing }\end{array}$ \\
& $\begin{array}{l}\text { Collaborate on PFM reform program. } \\
\text { Collaborate on financial sector reform program. }\end{array}$ & Ongoing \\
\end{tabular}




\section{APPENDIX III. RWANDA: STATISTICAL ISSUES}

Data provision has some shortcomings, but is broadly adequate for surveillance. National accounts, prices, government finance, and balance of payments statistics have various weaknesses which hamper economic analysis. Monetary statistics and data relevant for banking supervision are adequate for program monitoring, but there is some scope for improvements in quality and timeliness. The country has participated in the General Data Dissemination System since October 2003. However, the metadata has not been revised since the participation. In August 2005, the National Institute of Statistics of Rwanda (NISR) was established following the passage of the new Statistics Law.

\section{National Accounts and Price Statistics}

Annual GDP estimates in current and 2006 constant prices are compiled and disseminated by the NISR, based on the 1993 System of National Accounts concepts. Commendable efforts have been made by the NISR in recent years to improve the GDP estimates, with technical assistance being provided by the East AFRITAC and the United Nations Development Program. In particular, the NISR started to disseminate quarterly GDP estimates from the second quarter of 2010. Nevertheless, as a country with large agricultural and informal sectors, significant weaknesses still exist in GDP estimates from the production side:

- $\quad$ Agricultural production estimates are extrapolated using pre-harvest crop assessments, which mainly focus on food security rather than on measuring production growth, due to lack of ex-post crop assessment surveys. As the estimates resulting from the pre-harvest assessments are assumed to be generally higher than actual harvest, the NISR conducts ex-post visits and makes adjustments to the results of the pre-harvest survey. However, the adjustments made are limited to certain crops and the visits do not cover the entire nation, as it is a transitory attempt.

- $\quad$ Lack of a comprehensive economy-wide business survey precludes a reliable benchmark of economic activities in the private sector. Instead, proxy indicators such as monthly VAT turnover data covering the formal sector and financial data reported by a limited number of large companies are used to estimate the production.

- Economic activities in the informal sector are estimated every 5 years making use of household surveys. They are assumed to grow at the population growth rate, and currently occupy $19 \%$ of GDP. The assumption gives a bias to GDP estimates.

There are considerable issues to be addressed for GDP estimates under the expenditure approach, too. While the estimates of government consumption, gross capital formation, and trade in goods and services are compiled from data sources including government budget reports and balance of payment estimates, the rest of the components, private consumption and changes in inventories, are estimated as simply a gap between the sum of these components and a total GDP estimate from the production approach. For gross fixed capital 
formation, only the estimates of construction and durable equipment are compiled. These practices significantly hinder the reliable assessment of national savings and investment. Compilation of quarterly balance of payment estimates is necessary to improve the quality of estimates of trade, and enable the quarterly compilation of important statistics, such as gross nation income, national saving, and net lending/borrowing.

Recognizing these issues, the NISR has formulated an action plan providing a comprehensive list of actions to be taken by June 2013. The NISR is currently preparing for the third household budget survey (EICV3) to be conducted from November 2010 to October 2011 in order to produce benchmark data for the 2011 rebase of the national accounts. An enterprise survey is also planned to be implemented during 2012. The NISR will begin conducting expost crop assessments starting with the 2011 agricultural A season, and is planning to do a feasibility study further reviewing the crop assessment methodology.

The implementation of the action plan is challenging, illustrating the urgent need for securing additional staff and resources for the NISR. The NISR is significantly under staffed and under resourced. In this sense, it is admirable that the Cabinet approved a plan to increase the number of NISR staff from 40 to 100 and provided a necessary budget for FY2010. The NISR is expecting to have 70 staff members by the end of the year 2010 .

In October 2009, the consumer price index (CPI) was indexed to February 2009 and reweighted utilizing results from the second household budget survey. The survey was conducted in 2005-06, with a sample of 6,900 households. Now the index reflects expenditures of rural households in Rwanda, in addition to those of urban households. A quarterly PPI (base Q4 $2003=100$ ) has been produced for manufacturing activities since 2005.

10. Real sector data are reported regularly for publication in International Finance Statistics (IFS), although with some lag, particularly for GDP estimates. Data on employment and wages are not collected, except for the central government.

\section{Government Finance Statistics}

Detailed monthly revenues and expenditures are reported to AFR with a lag of five to six weeks. These data are compiled by the flash-reporting unit of The Ministry of Finance and Economic Planning (MINECOFIN). A functional classification of government expenditure has been available since the 2003 budget. Within the economic classification, expenditures on PRSP-designated "priority areas" are clearly identifiable. The fiscal data do not capture capital expenditure consistently because capital projects (almost entirely externally financed) are mainly carried out by line ministries outside the regular budget process. Compilation of data on external budgetary assistance as well as on external debt would benefit from strengthened coordination between the finance ministry and the central bank. Efforts are underway to integrate the development budget into the normal budgetary procedures. Fiscal data often exhibit discrepancies between deficit and financing estimates. To address these 
issues, the authorities have made adjustments for changes in the balance of non-core government accounts, changes in cash in vault at the revenue authority, accounting errors, and other factors.

No sub-annual data are reported to STA for publication in the IFS, and annual government finance statistics have not been reported for publication in the GFS Yearbook since 1993.

\section{Monetary and Financial Statistics}

The balance sheet of the NBR and detailed data on money market transactions are transmitted to AFR on a weekly basis with a lag of one week, while the monetary survey and the consolidated balance sheet of commercial banks are transmitted on a monthly basis with a lag of about five weeks. Detailed data on interbank money market transactions are also provided upon request. Monetary data used to be reported separately to STA and published in the IFS. The reporting of monetary statistics to STA has been delayed during the migration to the Standardized Report Forms (SRFs) undertaken by the NBR. The interruption in reporting has been longer than initially planned as the progress of the SRF migration has been hampered by the scarcity of skilled staff.

An August 2007 STA mission found that (i) a new chart of accounts for commercial banks was enacted in 2005 and the call report forms sent to the NBR were improved, better reflecting the methodology of the Monetary and Financial Statistics Manual; (ii) the data on the Union des banques populaires du Rwanda - a countrywide mutual bank network - were included in the broad money survey beginning January 2004; (iii) the data on credit and savings cooperatives and other microfinance institutions are still not included in monetary statistics.

\section{External Sector Statistics}

Balance of payments statistics are affected by weaknesses in the source data (treatment of customs data and bank settlement reports). The June 2003 multisector statistics mission recommended: (1) reorganizing data entry and production of external trade statistics, using ASYCUDA and Eurotrace software; (2) adapting survey forms sent to companies to the BPM5 methodology; and (3) collaborating with Central Public Investments and External Finance Bureau (CEPEX) to obtain data on international and bilateral aid. Subsequently, STA balance of payments statistics missions followed up in January 2004 and June 2005, as did AFRITAC missions in October 2006 and June 2007.

Technical assistance resulted in significant improvements. In particular, the collection of data through direct surveys now seems to be well established, and the rate of response is satisfactory (except for embassies). Data compilation was the main focus of the June 2006 AFRITAC mission, and many adjustments to customs data were introduced to improve coverage and valuation. The NBR has started compiling BOP/IIP statistics in conformity with the BMP5 methodology. Annual balance of payments and IIP data through 2007 have 
been reported to STA for publication in the IFS and the Balance of Payments Statistics Yearbook. The NBR in 2009-10 launched several initiatives to improve data coverage, including (1) a questionnaire on technical assistance related to NGOs; (ii) a cross-border trade survey capturing all information on trade transactions with neighboring countries which are not capture by the official customs system; and (iii) a revision of the estimates of participation of (non-)residents in import transportation services.

Nevertheless, some weaknesses remain, particularly in the compilation of trade data. The treatment of bank settlement reports is not effective, because of incomplete automation of the collection of declarations. The coverage of external aid remains a cause of concern. Data produced by the CEPEX do not include offshore payments, direct payments to contractors, and technical assistants, nor does it capture aid from important UN agencies and from certain countries. Only the external aid registered in the Government budget is fully covered. Concerning the NGO sector, the data should result from the survey of NGOs, but its coverage is insufficient.

Databases on external public debt are maintained by both MINECOFIN and the NBR. A committee, composed of staffs from the ministries of finance and economic planning, foreign affairs, and the NBR, is responsible for collecting, harmonizing, and monitoring information on external public debt. 
Table 1. Rwanda: Table of Common Indicators Required for Surveillance

(As of November 30, 2010)

\begin{tabular}{|c|c|c|c|c|c|}
\hline & $\begin{array}{l}\text { Date of Latest } \\
\text { Observation }\end{array}$ & $\begin{array}{l}\text { Date } \\
\text { Received }\end{array}$ & $\begin{array}{c}\text { Frequency } \\
\text { of } \\
\text { Data }^{7}\end{array}$ & $\begin{array}{l}\text { Frequency } \\
\text { of } \\
\text { Reporting }^{7}\end{array}$ & $\begin{array}{l}\text { Frequency } \\
\quad \text { of } \\
\text { Publication }^{7}\end{array}$ \\
\hline Exchange Rates & 09/08/2010 & 09/13/2010 & D & W & D \\
\hline $\begin{array}{l}\text { International Reserve Assets and Reserve } \\
\text { Liabilities of the Monetary Authorities }^{1}\end{array}$ & 09/08/2010 & $09 / 13 / 2010$ & W & W & M \\
\hline Reserve/Base Money & 09/08/2010 & $09 / 13 / 2010$ & W & W & M \\
\hline Broad Money & & & M & M & M \\
\hline Central Bank Balance Sheet & $09 / 03 / 2010$ & $09 / 13 / 2010$ & W & W & M \\
\hline $\begin{array}{l}\text { Consolidated Balance Sheet of the Banking } \\
\text { System }\end{array}$ & August 2010 & $10 / 18 / 2010$ & M & M & M \\
\hline Interest Rates ${ }^{2}$ & August 2010 & $10 / 18 / 2010$ & M & M & M \\
\hline Consumer Price Index & August 2010 & $10 / 18 / 2010$ & M & M & M \\
\hline $\begin{array}{l}\text { Revenue, Expenditure, Balance and } \\
\text { Composition of Financing }{ }^{3}-\text { General } \\
\text { Government }^{4}\end{array}$ & NA & NA & NA & NA & NA \\
\hline $\begin{array}{l}\text { Revenue, Expenditure, Balance and } \\
\text { Composition of Financing }{ }^{3}-\text { Central } \\
\text { Government }\end{array}$ & & & M & M & M \\
\hline $\begin{array}{l}\text { Stocks of Central Government and Central } \\
\text { Government-Guaranteed Debt }{ }^{5}\end{array}$ & August 2010 & $10 / 18 / 2010$ & A & A & A \\
\hline External Current Account Balance & 2009 & $\begin{array}{l}\text { March } \\
2010\end{array}$ & A & A & A \\
\hline Exports and Imports of Goods and Services & 2009 & $\begin{array}{l}\text { March } \\
2010\end{array}$ & A & A & A \\
\hline GDP/GNP & 2010 Q2 & $10 / 15 / 2010$ & Q & SA & Q \\
\hline Gross External Debt & 2009 & $\begin{array}{l}\text { March } \\
2010\end{array}$ & A & I & NA \\
\hline International Investment Position ${ }^{6}$ & 2007 & $10 / 09 / 2008$ & A & A & A \\
\hline
\end{tabular}

${ }^{1}$ Includes reserve assets pledged or otherwise encumbered as well as net derivative positions.

${ }^{2}$ Both market-based and officially-determined, including discount rates, money market rates, rates on treasury bills, notes and bonds.

${ }^{3}$ Foreign, domestic bank, and domestic nonbank financing.

${ }^{4}$ The general government consists of the central government (budgetary funds, extra budgetary funds, and social security funds) and state and local governments.

${ }^{5}$ Including currency and maturity composition.

6 Includes external gross financial asset and liability positions vis-à-vis nonresidents.

${ }^{7}$ Daily (D); Weekly (W); Monthly (M); Quarterly (Q); Annually (A); Semi-annually (SA); Irregular (I); Not Available (NA). 
This page intentionally left blank

CInternational Monetary Fund. Not for Redistribution 
Public Information Notice (PIN) No. 11/3

FOR IMMEDIATE RELEASE

January 11,2011
International Monetary Fund

$70019^{\text {th }}$ Street, NW

Washington, D. C. 20431 USA

\section{IMF Executive Board Concludes 2010 Article IV Consultation with Rwanda}

On December 20, 2010, the Executive Board of the International Monetary Fund (IMF) concluded the Article IV consultation with Rwanda. ${ }^{1}$

\section{Background}

Rwanda's economy is showing clear signs of recovery from the external and domestic shocks of the past two years, while inflation has remained low.

After slowing to 4.1 percent in 2009 from 11.2 percent in 2008, real GDP growth for 2010 is expected to reach 6.5 percent, driven by a rebound in exports and stronger-than-expected growth in services (mainly in telecommunications) and construction-sectors that were adversely affected by the global recession and tight liquidity. High-frequency macroeconomic indicators for the first three quarters of 2010 support the pickup in economic activity.

Higher export performance, reflecting a rebound in international prices and stronger-thanexpected volumes of coffee, tea, and non-traditional exports, has contributed to a narrowing of

\footnotetext{
${ }^{1}$ Under Article IV of the IMF's Articles of Agreement, the IMF holds bilateral discussions with members, usually every year. A staff team visits the country, collects economic and financial information, and discusses with officials the country's economic developments and policies. On return to headquarters, the staff prepares a report, which forms the basis for discussion by the Executive Board. At the conclusion of the discussion, the Managing Director, as Chairman of the Board, summarizes the views of Executive Directors, and this summary is transmitted to the country's authorities. An explanation of any qualifiers used in summings up can be found here: http://www.imf.org/external/np/sec/misc/qualifiers.htm.
} 
the external current account deficit (excluding grants) to 17.3 percent of GDP in 2010, from 18.6 percent in 2009 , while international reserves remain at comfortable levels.

For the first time in many years, annual inflation has remained below 5 percent in 2010, reflecting in large part the benign external environment, especially stable food and fuel prices.

Monetary policy has been accommodative, but private sector credit has been slow to respond, despite three cuts in the central bank's policy rate (the key repo rate) since November 2009 by 300 basis points.

Fiscal performance in FY 2009/10 was better than projected, reflecting better than projected domestic revenue collection while total expenditure including net lending remained on target.

In general, Rwanda's economy has a higher growth potential of about $8 \frac{1}{2}$ percent over the medium term, provided that (i) investment is scaled up significantly; (ii) productivity growth increases and remains elevated; and (iii) there are no adverse shocks. Achieving and maintaining this high growth rate, however, is challenging as it will require additional investments of at least $\$ 350$ million (or 7 percent of GDP) a year. Risks to the outlook are on the downside, reflecting mainly slower pickup in external demand and domestic credit. Donor flows are expected to remain strong, but decline gradually over the medium term. Over the longer term, risks to potential growth include lower levels of investment financing and smaller productivity gains. There are also upside risks to inflation from higher global food and fuel prices.

Rwanda's macroeconomic policies are supported by the IMF's Policy Support Instrument (PSI), which was approved in June 2010 (see Press Release No. 10/247). The proposed three-year PSI program aims to consolidate macroeconomic stability while reducing Rwanda's aid dependency by: (i) maintaining a sustainable fiscal position through improved revenue mobilization; (ii) strengthening monetary and exchange rate policies to ensure low and stable inflation; (iii) reducing financial sector vulnerability by strengthening banking supervision, and deepening the financial sector by enhancing access to credit; and (iv) diversifying the export base and improving the business environment.

\section{Executive Board Assessment}

Executive Directors commended the Rwandan authorities for satisfactory implementation of the economic program supported under the PSI. Countercyclical fiscal and monetary policies helped to mitigate the impact of the global economic downturn and contributed to a rebound in economic activity. Directors noted that the recovery remains fragile.

Continued prudent policies, improved infrastructure, increased agricultural productivity, and deepened financial markets will be needed to sustain growth and reduce poverty.

Directors welcomed the authorities' intention to gradually unwind fiscal stimulus and to embark on a medium-term path toward fiscal consolidation. They encouraged the authorities to consider 
complementing revenue mobilization efforts with tax policy reforms and supported further strengthening of the medium-term fiscal framework underlying the planned fiscal consolidation. Such improvements include better costing of government spending plans in the Medium-Term Expenditure Framework, improved alignment of external grants with a medium-term domestic debt strategy, and quarterly dissemination of fiscal data.

Directors commended the authorities for their progress in reforming public financial management, and emphasized the importance of further enhancing public expenditure accountability and efficiency. They noted that strengthening of public investment planning and evaluation and of debt management capacity would be critical for scaled-up infrastructure spending, in particular when using nonconcessional financing.

Directors underscored the importance of regular review of the monetary policy stance to enable timely response to any underlying inflationary pressures. They recognized the challenges involved in strengthening the monetary transmission mechanism, and encouraged more active use of the policy rate and development of an active debt market with longer-dated instruments. Directors emphasized the importance of continued analytical support for the Monetary Policy Committee deliberation process and supported continuation of reforms toward greater exchange rate flexibility.

Directors noted staff's assessment that Rwanda's real effective exchange rate was broadly in line with economic fundamentals. They underscored the importance of continued improvements in the business environment and stepped up efforts on structural reforms to broaden the export base.

Directors welcomed efforts to improve access to finance, but cautioned that accelerating the expansion of micro finance institutions and savings and credit cooperatives should be balanced by having in place the necessary supervisory capacity. They emphasized the importance of developing and implementing a plan to build and retain banking supervision staff. Directors stressed the importance of enhancing competition in the banking sector.

Directors encouraged the authorities to improve quality of statistics, particularly in the areas of the national accounts and the balance of payment.

Public Information Notices (PINs) form part of the IMF's efforts to promote transparency of the IMF's views and analysis of economic developments and policies. With the consent of the country (or countries) concerned, PINs are issued after Executive Board discussions of Article IV consultations with member countries, of its surveillance of developments at the regional level, of post-program monitoring, and of ex post assessments of member countries with longer-term program engagements. PINs are also issued after Executive Board discussions of general policy matters, unless otherwise decided by the Executive Board in a particular case. 
Rwanda: Selected Economic and Financial Indicators

\begin{tabular}{rllllllll}
\hline & 2006 & 2007 & 2008 & 2009 & & 2010 & & 2011 \\
\cline { 5 - 7 } & & & & Est. & Prog. & Proj. & Proj. \\
\hline
\end{tabular}

(Annual percentage changes, unless otherwise indicated)

\section{Output and prices}

Real GDP growth

Real GDP per capita

GDP deflator

Consumer prices (period average)

Consumer prices (end of period)

\section{External sector}

Export of goods, f.o.b (in U.S. dollars)

Imports of goods, f.o.b (in U.S. dollars)

Terms of trade (deterioration $=-$ )

\section{Money and credit $1 /$}

Net domestic assets $2 /$

Domestic credit 2/

Government 2/

Reserve money $3 /$

$\begin{array}{rrrrrrr}9.2 & 5.5 & 11.2 & 4.1 & 5.4 & 6.5 & 6.5 \\ 7.3 & 3.3 & 8.9 & 2.0 & 3.2 & 4.3 & 4.3 \\ 9.8 & 13.2 & 12.6 & 11.0 & 6.7 & 3.8 & 5.2 \\ 8.8 & 9.1 & 15.4 & 10.3 & 6.4 & 3.2 & 5.3 \\ 12.1 & 6.6 & 22.3 & 5.7 & 7.0 & 4.6 & 6.0\end{array}$

\begin{tabular}{rrrrrrr}
17.9 & 19.9 & 51.4 & -28.0 & 24.6 & 48.1 & -0.4 \\
26.2 & 30.2 & 51.5 & 16.4 & 19.1 & 11.9 & 19.6 \\
5.5 & 20.9 & -1.4 & -15.4 & 2.9 & 23.6 & -10.1 \\
& & & & & & \\
2.6 & 7.6 & 10.3 & 4.9 & 10.9 & 11.8 & 10.5 \\
8.2 & 12.0 & 20.5 & 3.8 & 11.0 & 16.2 & 9.1 \\
-5.6 & 0.2 & -18.1 & 0.2 & -2.5 & 8.6 & -5.8 \\
11.9 & 30.7 & 23.5 & 0.3 & 12.5 & 11.7 & 13.9 \\
\multicolumn{7}{c}{ (Percent of GDP) }
\end{tabular}

National income accounts

National savings

Gross investment

Of which: private (including public enterprises)

\begin{tabular}{|c|c|c|c|c|c|c|}
\hline 7.4 & 8.3 & 9.1 & 3.8 & 3.5 & 6.1 & 4.0 \\
\hline 9.7 & 20.2 & 23.5 & 22.4 & 22.8 & 23.4 & 24 \\
\hline 12.8 & 12.4 & 13.1 & 12.4 & 11.7 & 12.6 & 13.0 \\
\hline
\end{tabular}

\section{Government finance 4/}

Total revenue (excl. grants)

Total expenditure and net lending

Capital expenditure

Current expenditure

Overall fiscal balance (payment order) 4/

After grants

Before grants

$\begin{array}{rrrrrrr}12.2 & 12.4 & 12.6 & 14.9 & 12.2 & 12.5 & 13.6 \\ 23.7 & 22.0 & 22.6 & 26.4 & 25.9 & 25.8 & 27.3 \\ 7.6 & 7.0 & 8.2 & 11.1 & 9.8 & 10.1 & 11.6 \\ 15.9 & 14.2 & 15.1 & 14.5 & 14.9 & 14.7 & 14.8 \\ & & & & & & \\ 5.2 & -1.4 & -0.2 & -2.2 & -1.1 & -0.1 & -3.6 \\ -11.5 & -9.6 & -10.0 & -11.5 & -13.7 & -13.2 & -13.8\end{array}$

\section{External sector}

External current account balance

Including official transfers

Excluding official transfers

External debt (end of period)

Gross reserves (in months of imports of goods and services) 5/

\begin{tabular}{rrrrrrr}
-4.3 & -2.2 & -4.9 & -8.5 & -7.9 & -6.7 & -9.0 \\
-12.3 & -11.9 & -14.4 & -18.6 & -19.3 & -17.3 & -20.2 \\
15.6 & 15.3 & 14.4 & 14.5 & 16.4 & 14.9 & 17.7 \\
5.6 & 4.7 & 4.6 & 5.5 & 4.8 & 4.6 & 5.2 \\
& \multicolumn{7}{c}{ (Millions of U.S. dollars) } \\
439.6 & 552.4 & 596.4 & 742.2 & 744.3 & 737.2 & 767.3 \\
& & & & & & \\
1,716 & 2,049 & 2,565 & 2,964 & 3,333 & 3,278 & 3,672 \\
\hline
\end{tabular}


Sources: Rwandan authorities and IMF staff estimates and projections.

1/ Projections are based on the program exchange rate of RwF per US dollar of 571.24.

2/ As a percent of the beginning-of-period stock of broad money.

$3 /$ Increase in 2 percent after correcting for the rebasing at end-2006.007 reflects rebasing of the monetary program; reserve money growth

was limited to 13 percent after correcting for the rebasing at end-2006.

4/ On a fiscal year basis (July-June). For example, the column ending in 2011 refer to FY2010/11. Column 2011 is therefore the program column for

fiscal data.

5/ Data from 2009 onwards includes SDR Allocation. 
This page intentionally left blank

CInternational Monetary Fund. Not for Redistribution 
Press Release No. 10/505

FOR IMMEDIATE RELEASE

December 20, 2010
International Monetary Fund

Washington, D.C. 20431 USA

\section{IMF Executive Board Completes First Review Under Policy Support Instrument for Rwanda}

The Executive Board of the International Monetary Fund (IMF) today completed the first review under the three-year Policy Support Instrument (PSI) for Rwanda. The Executive Board also approved modifications of assessment criteria under the PSI.

The PSI for Rwanda was approved on June 16, 2010 (see Press Release No. 10/247) and is aimed at consolidating macroeconomic stability, achieving sustained broad-based growth, and reducing Rwanda's aid dependency. The program focuses on maintaining a sustainable fiscal position; strengthening monetary and exchange rate policies; and supporting growth with structural reforms to diversify the export base and improving the business environment.

Following the Executive Board's discussion on Rwanda, Mr. Murilo Portugal, Deputy Managing Director and Chairman, stated:

"The Rwanda authorities are to be commended for satisfactory implementation of the economic program supported by the Policy Support Instrument for 2009/10, carried out against the backdrop of a global economic downturn. Rwanda's economy is showing clear signs of recovery from the external and domestic shocks of the past two years. However, uncertainty in external demand, a slow pick-up in credit to the private sector, and the need to secure favorable financing to implement their investment plan to close the infrastructure gap continue to pose policy challenges.

"The authorities are gradually unwinding the fiscal stimulus while at the same time mobilizing additional domestic revenues and protecting priority spending. Monetary policy has been accommodative to rekindle credit to the private sector and further support growth. The authorities are committed to regularly assess the inflation outlook in order to safeguard the gains made in macroeconomic stability that currently underpin the economic recovery. 
"The authorities are aware of the need to deepen the domestic financial markets to support the growing economy, and are implementing a program to increase access to credit through additional licensing of micro finance institutions and saving and credit companies. Given rising levels of non-performing loans, further efforts are needed to strengthen bank and nonbank supervision to ensure that higher access to credit does not endanger financial stability." 


\section{Statement by Kossi Assimaidou, Executive Director for Rwanda December 20, 2010}

My Rwandan authorities would like to thank staff for the fruitful discussions held in Kigali during their last visit. They would also like to extend their gratitude to the Executive Board and Management for their continued support which has helped Rwanda reach important milestones on the path of economic progress.

The achievements on the fronts of macroeconomic stability and building an enabling environment for a private sector led growth have engineered robust and sustained output over the last decade and also strengthened the resilience of the Rwandan economy to crises. Thus, after suffering the impact of the global slowdown over the past two years, the economy is resuming its momentum, thanks to the appropriate policies my authorities are implementing under the PSI to cope with the various shocks stemming from the crisis. Despite an unfavorable international environment and other challenging domestic conditions, my authorities have posted a satisfactory performance over the period under review, meeting all quantitative assessment criteria and making good progress on key structural reforms.

Going forward, my authorities are cognizant of the daunting challenges still facing the economy and the country as a whole. Efforts should be stepped up to diversify growth engines, reduce aid dependency, and curb down the still high poverty rate as envisaged in the government's Economic Development and Poverty Reduction Strategy (EDPRS) 2008-2012. My authorities are committed to keeping up their track record of sound policymaking while they endeavor to address those challenges.

\section{Recent Economic Developments and Performance under the PSI}

The satisfactory implementation of the PSI has helped Rwanda turn around the adverse impact of the global crisis and improve the overall economic situation as evidenced by recent developments. Real GDP growth is expected to reach 6.5 percent at end-year 2010, higher than the 4.1 percent in 2009 , though still well below its pre-crisis level of 11.2 percent in 2008. Key drivers that suffered the impact of slowing global demand are recovering buoyancy, notably, exports, services, tourism, and construction. This recovery is taking place in a more stable macroeconomic environment, with inflation lying in low single digits. The external sector is benefiting from the export rebound and reserves are projected to cover 4.6 months of imports at end-year.

Fiscal performance was on track. Domestic revenue exceeded targets by about 0.7 percent of GDP, as a result of overperforming taxes on goods and services and direct taxes. Spending was in line with the program, though foreign financed capital projects suffered delays in external loan disbursements. My authorities' fiscal policy was also marked by a large stimulus in 2009/10 - of about 2 percent of GDP- as a response to the global crisis. Going forward, my authorities are committed to gradually unwinding the fiscal stimulus and renewing with their efforts of fiscal consolidation. 
Monetary and exchange rate policy has been accommodative to boost growth in the face of the adverse international situation. The NBR pursued a twofold strategy of repeated cuts in the policy rate and lowering of reserve requirement on bank deposits. Owing to the cautious attitude of banks and the still weak monetary policy transmission mechanism, credit growth has taken time to respond, but is expected to increase to 10 percent by December 2010 against 6 percent at end-December 2009. My authorities will continue their efforts of deepening the financial sector with the view to improving monetary policy transmission channels and thus enhancing credit to the private sector. Overall, they are committed to further improving the conduct of monetary and exchange rate policy, including by building capacity, improving the functioning of the monetary policy committee, and fine tuning the mix of instruments.

As regards the financial sector, my authorities and staff share the view that the banking sector generally remains sound, profitable, and well capitalized. The capital adequacy ratio of the banking system stood at 17.6 percent as of June 30, 2010. Asset quality slightly improved, with NPLs decreasing from 13.1 percent in December 2009 to 12.2 percent at end June 2010. Bank profitability also increased; at end June 2010, return on equity and return on assets increased respectively from 6.4 percent to 10.3 percent and from 0.9 percent to 1.3 percent compared to June 30, 2009. Still, my authorities are well aware of the steps that need to be taken to build a strong financial sector covering the large unbanked segments of the population and capable of supporting a robust private sector activity.

\section{Challenges and Policies Going Forward}

My Rwandan authorities are committed to pursuing the good implementation of the PSI. Their agenda for the period ahead encompasses policies that will help maintain macroeconomic stability and achieve robust and sustainable broad-based growth and poverty reduction. In that regard, my authorities intend to take measures to further unleash growth potential. Fiscal and monetary policies will be conducted accordingly. My authorities will also work expeditiously to address a number of bottlenecks and weaknesses that still constrain the economy.

\section{Boosting competitiveness to realize growth potential}

My Rwandan authorities fully agree with staff on the favorable economic outlook and will conduct policies to boost competitiveness and realize growth potential. Their core objective in this regard is to post real output growth well above 7 percent over the medium term. To this end, my authorities intend to pursue reforms aimed at creating an enabling environment for the private sector, provide economic infrastructure through strategic investments, develop further the financial sector to boost credit, and implement an export strategy to tap into external markets.

Specifically, building on the favorable ranking in the 2010 global competitiveness indicators and World Bank Doing Business rankings, my authorities will step up efforts to attract more private investment, by granting tax incentives and exemptions. My authorities are determined 
to lift infrastructure bottlenecks by implementing an ambitious investment strategy through mechanisms such as PPPs. As for exports, the exchange rate policy will accommodate the need to remain competitive, while a diversification strategy will be pursued away from traditional products, for which niche markets will be explored.

\section{Gradually fostering fiscal consolidation}

My authorities have conducted countercyclical policies over the past period to dampen the impact of the global crisis. The fiscal stimulus that was implemented in this regard has served the country well, but also adversely impacted the overall deficit. As the recovery takes hold, my authorities are committed to resuming their effort of medium term fiscal consolidation. Over the next three years, my authorities plan to conduct a twofold strategy of reducing the level of spending by 0.2 percent of GDP per annum on average and boost domestic revenue mobilization by 0.6 percent of GDP per annum on average.

As for the revenue loss stemming from the membership in the East African Community (EAC) and COMESA (Common Market for Eastern and Southern Africa), my authorities have taken temporary measures of spending cuts and intend to conduct extensive analysis on the issue with the view to adopting permanent measures. My authorities' fiscal policy will also emphasize enhanced reforms in PFM, drawing on the PEFA assessment as well as their continued partnership with the donor community and the IMF's East AFRITAC.

\section{Strengthening the financial sector}

Cognizant of the need to build a deep financial sector as an underlying condition for a dynamic private sector, my authorities are taking important steps, both to strengthen the banks and financial companies and improve regulation and supervision. In terms of deepening and diversifying the financial market, the authorities recently granted licenses to some 400 Savings and Credit Cooperatives (SACCOs) to operate as deposit-taking institutions, before later granting them lending licenses as well. Banking regulations have been adopted this year, as well as other elements of the legal framework. The NBR will strengthen its supervision by building adequate capacity, and will put particular emphasis on microfinance institutions with its newly adopted package of regulatory and institutional reforms.

\section{Further reducing poverty}

With 57 percent of the population living below the national poverty line in 2006, reducing poverty remains the overarching goal of my Rwandan authorities as reaffirmed in their EDPRS. Progress has been made in this regard. The government's development program in the agriculture sector, where most poor populations live, is recording appreciable results. The country is now on track to achieve health and education-related MDGs, including increasing the coverage and the quality of basic and tertiary education, and strengthening technical and vocational education and training. It has already achieved MDGs related to gender equality and has also made good progress towards increasing access to water and sanitation for its population. Progress has also been made in the improvement of basic infrastructure, 
including roads and electricity provision. My authorities are committed to stepping up their efforts aimed at further empowering the most vulnerable segments of the population with the view to lifting them out of poverty.

\section{Conclusion}

The PSI program offers an adequate framework to my Rwandan authorities to consolidate the impressive results achieved in policymaking over the past decade with the support of the international community including the Fund. During the period under review, my authorities have successfully dealt with an adverse global environment marked by a deep crisis that turned into recession. Despite the severe impact on the Rwandan economy, my authorities have taken appropriate measures that helped maintain output in relatively good shape, and a stable macroeconomic situation.

The performance under the PSI has been satisfactory, and the economy is regaining momentum. My authorities are fully committed to fostering this recovery by keeping pace with the reforms. In this endeavor, my authorities continue to count on the support of their partners, especially the Fund to help make further inroads on the path of growth and poverty reduction. 